Prepared in cooperation with the U.S. Energy Information Administration

\title{
Critical Analysis of World Uranium Resources
}

Scientific Investigations Report 2012-5239 


\section{Critical Analysis of World Uranium Resources}

By Susan Hall and Margaret Coleman

Prepared in cooperation with the U.S. Energy Information Administration

Scientific Investigations Report 2012-5239 


\section{U.S. Department of the Interior \\ KEN SALAZAR, Secretary \\ U.S. Geological Survey \\ Marcia K. McNutt, Director}

U.S. Geological Survey, Reston, Virginia: 2013

For more information on the USGS — the Federal source for science about the Earth, its natural and living resources, natural hazards, and the environment, visit http://Www.usgs.gov or call 1-888-ASK-USGS.

For an overview of USGS information products, including maps, imagery, and publications, visit $h t t p: / / w w w . u s g s . g o v / p u b p r o d$

To order this and other USGS information products, visit http://store.usgs.gov

Any use of trade, firm, or product names is for descriptive purposes only and does not imply endorsement by the U.S. Government.

Although this information product, for the most part, is in the public domain, it also may contain copyrighted materials as noted in the text. Permission to reproduce copyrighted items must be secured from the copyright owner.

Suggested citation:

Hall, Susan, and Coleman, Margaret, 2013, Critical analysis of world uranium resources: U.S. Scientific Investigations Report 2012-5239, 56 p. 


\section{Contents}

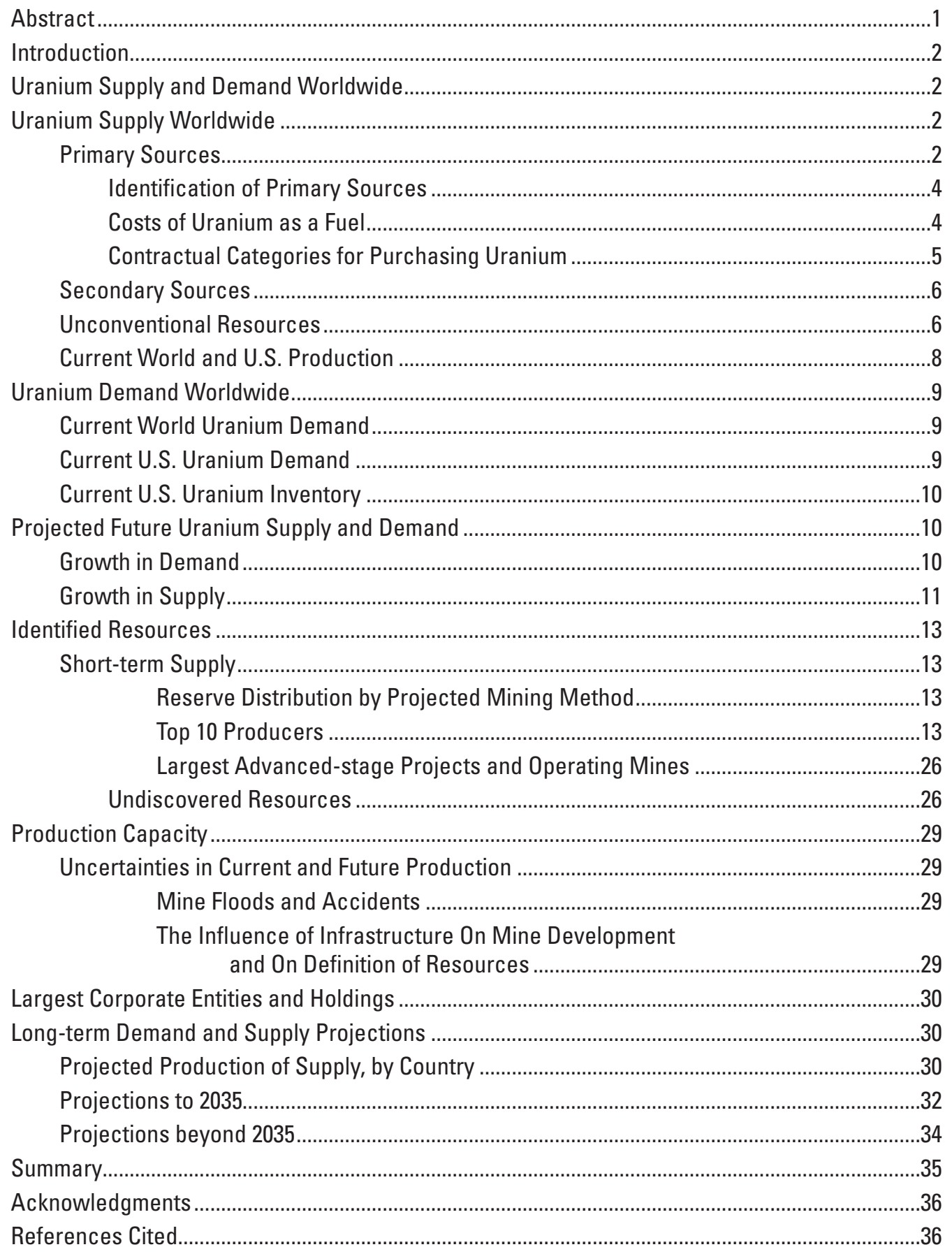


Appendix 1. Analysis of Operating Mines and Advanced-Stage Uranium Properties, by Country ....... 41

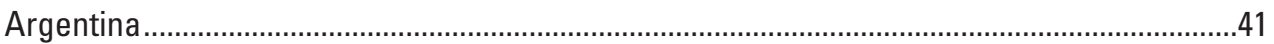

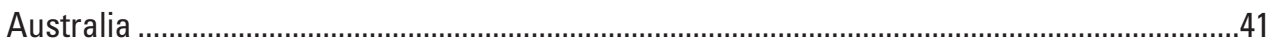

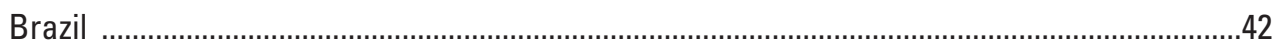

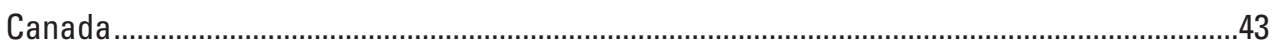

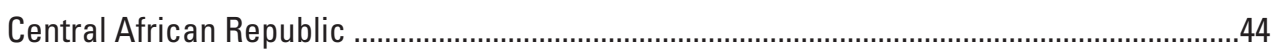

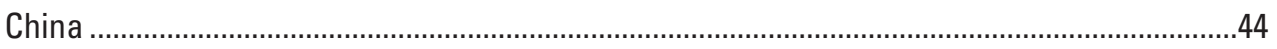

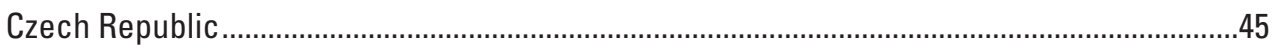

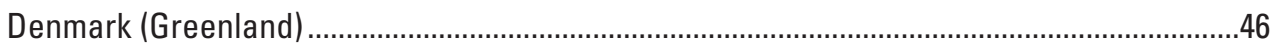

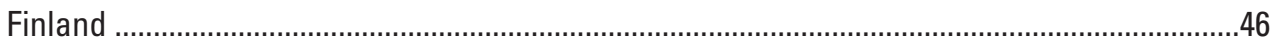

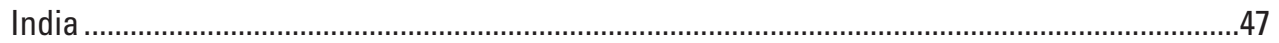

Iran

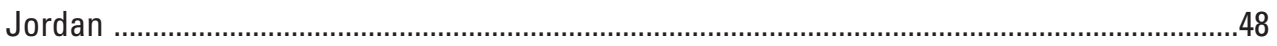

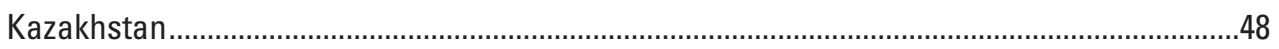

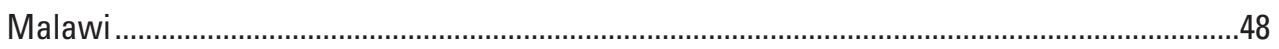

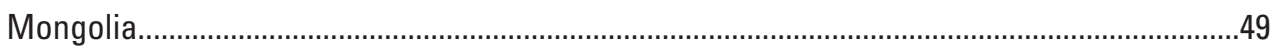

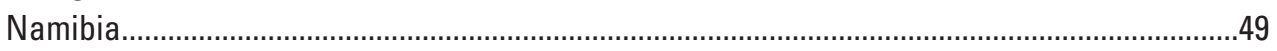

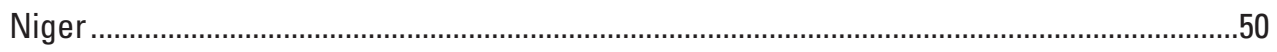

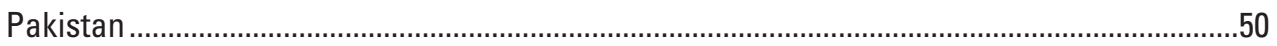

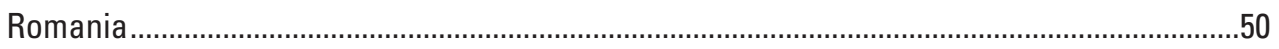

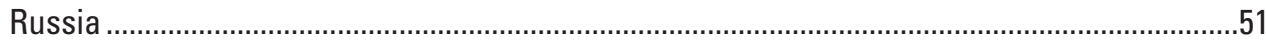

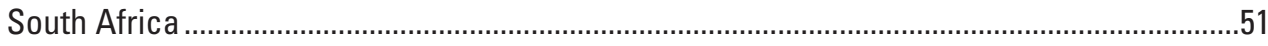

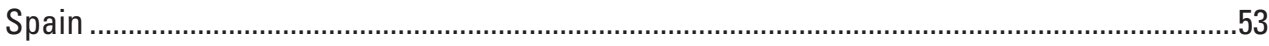

Ukraine

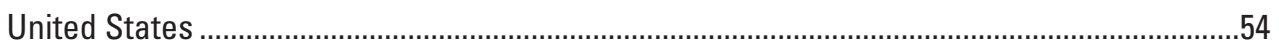

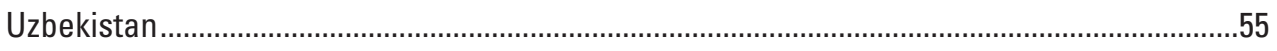

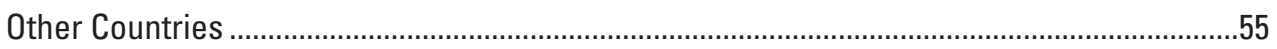

\section{Figures}

1. Schemes for classifying geological assurance of uranium resources, as used by six international agencies concerned with the mining of ores...............................................vii

2. Historic uranium production and nuclear powerplant requirements, $1945-2009$..............3

3. Elapsed time between discovery of a uranium mine and the start of mining,

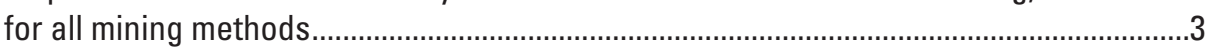

4. Uranium exploration expenditures and resources identified during 1975-2009...............4

5. Uranium prices in U.S. dollars per pound of uranium oxide $\left(\mathrm{U}_{3} \mathrm{O}_{8}\right)$, by type of contract, by major buyers, 1978-2009 ...........................................................................

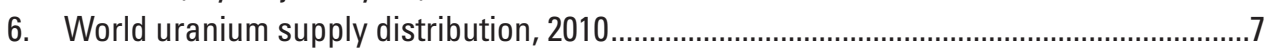

7. Contribution of primary and secondary uranium sources worldwide, projected to 2020

8. U.S. production, purchases, and sales of uranium, 1949-2008 (Energy Information Administration, 2010b)

9. Net generation of electricity worldwide, in trillions of kilowatt hours, by all fuels, 2007-2035 (Energy Information Administration, 2010c).

10. Uranium in fuel assemblies, in thousand pounds of uranium oxide equivalent loaded into U.S. civilian nuclear power reactors, by originating source, by year, 2005-2009....10

11. Uranium purchased by owners and operators of U.S. civilian nuclear power reactors, by selected country of origin and by delivery year, 2005-2009. 
12. Maximum anticipated uranium market requirements of owners and operators of U.S. civilian nuclear power reactors, 2010-2019, as of December 31, 2009.

13. Uranium Resources Mapped to Resource Category Geological assurance for, and economic feasibility of, worldwide uranium resources, by resource categories used by the Organisation for Economic Co-operation Nuclear Agency and

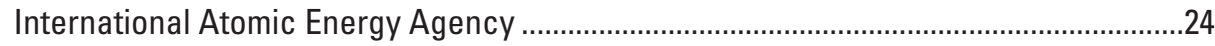

14. Prognosticated resources of countries reported as having more than $11,000 \mathrm{tU}$............28

15. Speculative resources for countries reporting more than $60,000 \mathrm{tU}$.............................28

16. Uranium production by company in 2010. Data from the World Nuclear Association, (2011b).

17. Distribution of resources among the top 9 world uranium producers in 2010 ................30

18. Existing uranium production and projected trends in production worldwide, 1998-2030.

19. Distribution of reasonably assured resources (RAR) in Nuclear Energy Agency cost categories for the most resource-rich countries .......................................31

20. World net electricity generation from nuclear power, by region, 2007-2030 ..................32

21. Scenarios for production of and requirements for uranium, 2011-2035 .........................33

23. World Nuclear Association projections for future nuclear capacity worldwide,

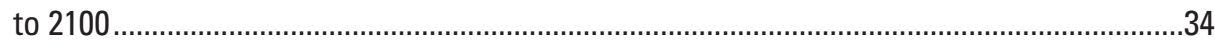

22. Actual and projected world trends in growth of market demand and increase of supply, 2008-2030.

\section{Appendix Figures}

1-1. Location of uranium mines in Argentina, 2010 ................................................................41

1-2. Location of operating mines producing uranium in Australia ..........................................41

1-3. Uranium active and developing mines in Brazil .............................................................4

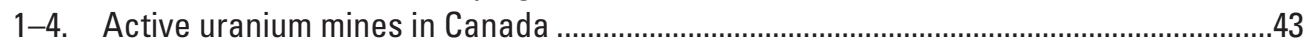

1-5. Location of the Bakouma deposit, Central African Republic .........................................4

1-6. Major uranium production centers in China .................................................................4

1-7. Uranium production centers in the Czech Republic ...................................................45

1-8. Location and geology of the Kvanefjeld deposit, Greenland..........................................46

1-9. Location of the Talvivaara uranium deposit in Finland ...................................................46

1-10. Location of current production centers and prospective areas of India .........................47

1-11. Location of the Gachin mine and the Saghand uranium deposit, Iran ............................47

1-12. Location of major uranium mining districts and operating mines of Kazakhstan............48

1-13. Location of the Kayelekera Mine in Malawi ..................................................................48

1-14. Location of the Dornod Uranium Project, Mongolia ...........................................................49

1-15. Approximate location of operating uranium mines and advanced-stage

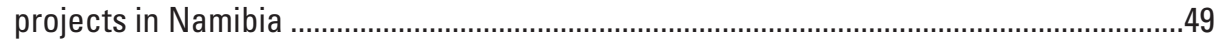

1-16. Location of uranium mines and advanced stage projects in Niger ................................50

1-17. Location of uranium mines, production centers and advanced properties

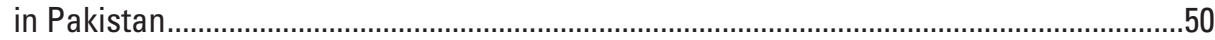

1-18. Major uranium mining regions of Romania …………..................................................

1-19. Location of major Russian uranium mining and processing districts.............................51

1-20. Locations of the two operating mines (Ezulwini and Vaal River) and of one mine on

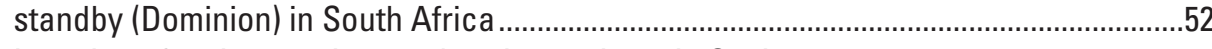

1-21. Location of active uranium exploration projects in Spain .............................................53

1-22. Uranium production centers in Ukraine.......................................................................53

1-23. Uranium province map of the United States …………...............................................54

1-24. Active uranium mining districts in Uzbekistan................................................................5 


\section{Tables}

1. Top ten uranium producing mines in 2009: production, reasonably assured resources, and mine life

2. World's largest deposits in stages of operation, development, feasibility or prefeasibility, 2010

3. Operating uranium mines and their remaining reasonably assured resources, 2010 ........16

4. Uranium properties that are permitted, or in feasibility or in the prefeasibility stages and their reported resources, 2010..................................................................20

5. Reasonably assured resources reported in the 2009 Red Book ( NEA-IAEA, 2010) ..........25

6. Reasonably assured resources (RAR) and production capacity of operating and proposed mines by extraction technology

7. Undiscovered resources, in thousands of tonnes uranium metal, as reported in the "2009 Red Book" ( NEA-IAEA, 2010).

\section{Appendix Table}

1-1. Chinese uranium mines and associated production centers inferred for these mines

\section{Conversion Factors, Definitions, and Abbreviations}

Metric units are used throughout this report because international reporting uses these terms. Uranium resources are reported as metric tonnes [of] contained uranium metal (tU). In discussions of rates of use, the abbreviation $\mathrm{tU} / \mathrm{yr}$ denotes metric tonnes of uranium per year. In the U.S. domestic mining industry, the more commonly used unit is pounds (Ibs.) uranium oxide $\left(\mathrm{U}_{3} \mathrm{O}_{8}\right)$. For convenience, 1 metric tonne is usually written 1 tonne. International usage reports uranium concentration in ore as percent $\mathrm{U}$ (uranium metal), not percent $\mathrm{U}_{3} \mathrm{O}_{8}$ (uranium oxide).

Useful conversion factors are:

$$
\begin{aligned}
& 1 \text { short ton } \mathrm{U}_{3} \mathrm{O}_{8}=0.769 \mathrm{tU} \\
& 1 \text { percent } \mathrm{U}_{3} \mathrm{O}_{8}=0.848 \text { percent } \mathrm{U}
\end{aligned}
$$

Cost categories are reported in U.S. Dollars (USD). Converting U.S. pounds into kilograms, the price in U.S. dollars per pound ( $=2.6$ kilograms $(\mathrm{kg})$ ) of uranium oxide is written as equivalent to the price in U.S. dollars per $\mathrm{kg}$ of uranium metal:

1 USD (U.S. Dollar)//b. $\mathrm{U}_{3} \mathrm{O}_{8}=$ USD $2.6 / \mathrm{kgU}$

Uranium resources are reported in categories that are based on the degree of geological assurance for, and the economic feasibility of, extraction of the ore. This report states resources in terms of being economically feasible to extract and that have been explored sufficiently such that the limits and geological extent of the properties of the deposit are well constrained, typically by drill data. Throughout this report, the term Reasonably Assured Resources (RAR) is used to describe this class of resource. Other classification systems assign different terms to such resources. This report's usage corresponds roughly to the U.S. Department of Energy (DOE) classification "reserves recoverable at less than USD 50 per pound uranium oxide" (<USD 50/lb. $\mathrm{U}_{3} \mathrm{O}_{8}$ ), equivalent to USD 130 per kilogram uranium metal (USD 130/kgU); it corresponds to measured and indicated reserves in the U.S. Geological Survey (USGS) classification system; to economic demonstrated resources in the Australian national scheme; to proved and probable reserves as used by Australasia's Joint Ore Reserves Committee (JORC); and to measured and indicated resources of the Canadian Institute of Mining, Metallurgy and Petroleum (CIM) (fig. 1). 
Decreasing degree of geological assurance

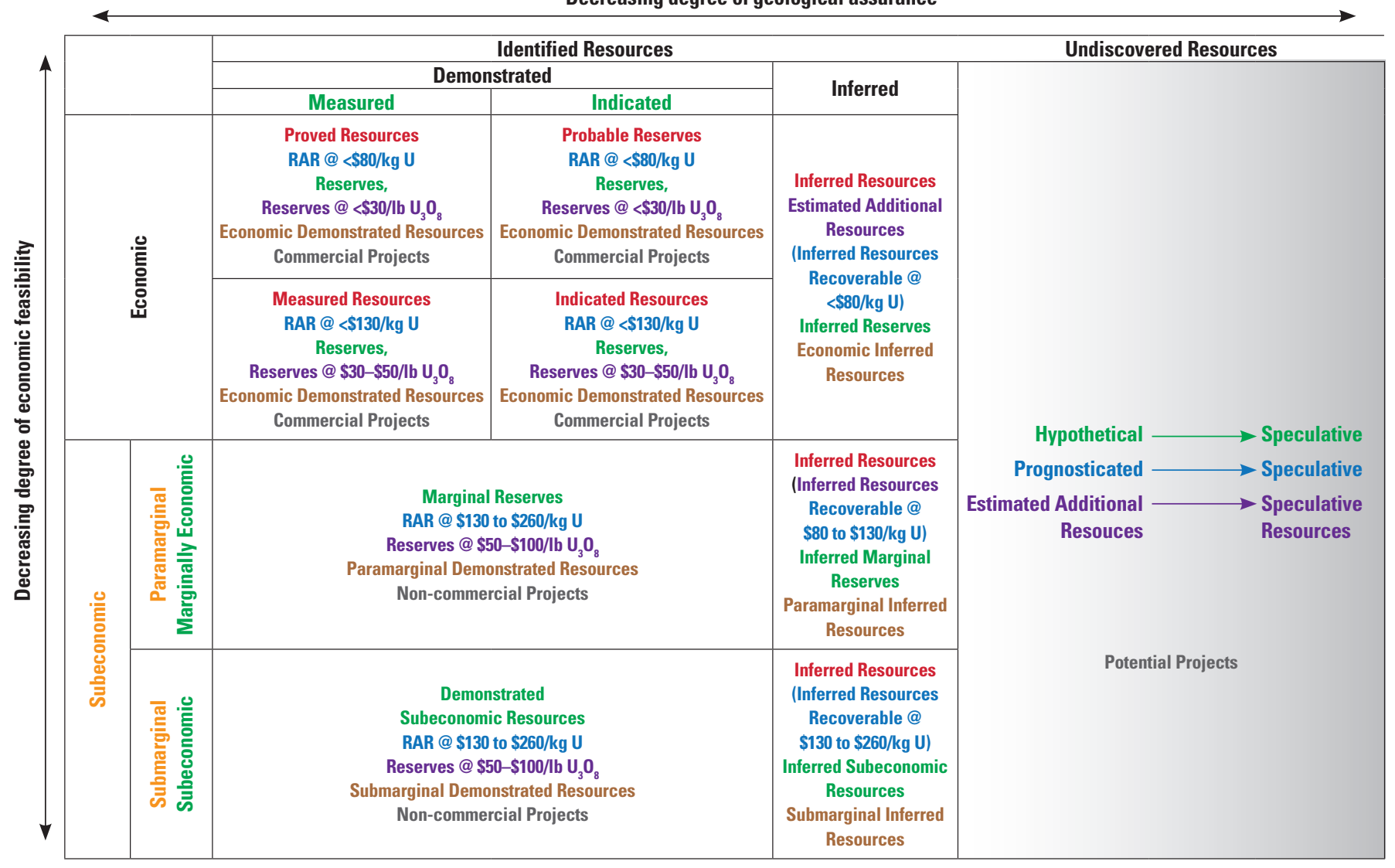

\begin{tabular}{|l|ll}
\hline Other Occurences & Includes nonconventional and low-grade materials
\end{tabular}

\section{All schemes excluding IAEA}

IAEA Scheme - RAR - Reasonably Assured Resources (losses resulting from mining/milling deducted, and cost categories from 2009 Red Book)

JORC (Australian Joint Ore Reserves Committee) Scheme

JORC (Australian Joint Ore Reserves Committee) \& CIM (Canadian Institute of Mining) Schema

USGS Scheme (USGS Circular 831,1980)

DOE - Note: DOE does not include inferred resources when reporting reserves, but includes them as part of Estimated Additional Resources (EAR)

Australian National Scheme (losses resulting from mining and milling deducted; Australia reports a category "Accessible Economic Demonstrated Resources" which subtracts deposits that cannot be currently mined-national parks, etc.)

Canada - Natural Resources Canada

UNFC (United Nations Framework Classification for Fossil Energy and Mineral Reserves and Resources) adds a third dimension to resource classifications,

"E" - Economic and social viability (reasonable prospects for eventual economic extraction) in addition to "G" - geologic knowledge, and "F" project status and feasibility. Available at: http://www.unece.org/energy/se/pdfs/UNFC/oct09/ECE.ENERGY.GE.3.2009.L.5_draft_e.pdf

The system does not correlate completely with other schema, but its general correlation with other systems is shown above.

For Inferred Resources, UNFC would require deposits to be classified by numeric coding from 1 (most viable) to 4 (least viable)

\$: U.S. Dollars

Figure 1. Schemes for classifying geological assurance of uranium resources, as used by six international agencies concerned with the mining of ores. 
Less assured resources-those in the Inferred category, those that are subeconomic, or those that are hypothetical or as yet undiscovered - are included in this analysis only in sections of the text that project future uranium supply beyond the approximately 20 -year timelines that are customary for development. Inferred resources are reported in the cost categories used by the Organisation for Economic Co-operation and Development Nuclear Energy Agency (NEA). The present report analyzes these categories when it separately examines the uranium supply in 24 countries and their scenarios for future development of supply (appendix 1). The text clearly identifies these resources as being more speculative wherever it discusses them.

Following International Atomic Energy Agency (IAEA) and Organisation for Economic Co-operation and Development, Nuclear Energy Agency (NEA) protocols, this report applied recovery factors to in-situ resources in order to determine the amount of uranium available after mining and processing, depending on type of mining (NEA-IAEA, 2010). Recovery can be determined with certainty only after mining is completed, because it depends on the metallurgy of the deposit and on the mining and processing methods, all of which can vary widely from deposit to deposit and during the entire course of mining. Estimated recovery adds a measure of uncertainty to analysis of the adequacy of uranium resources to satisfy demand. To minimize this bias, USGS and EIA followed standard recovery factors used by NEA and IAEA.

EIA U.S. Department of Energy Energy Information Administration

USGS U.S. Department of the Interior Geological Survey

NEA Organisation for Economic Co-operation and Development - Nuclear Energy Agency

IAEA International Atomic Energy Agency 


\title{
Critical Analysis of World Uranium Resources
}

\author{
By Susan Hall ${ }^{1}$ and Margaret Coleman ${ }^{2}$
}

\section{Abstract}

The U.S. Department of Energy, Energy Information Administration (EIA) joined with the U.S. Department of the Interior, U.S. Geological Survey (USGS) to analyze the world uranium supply and demand balance. To evaluate shortterm primary supply ( $0-15$ years), the analysis focused on Reasonably Assured Resources (RAR), which are resources projected with a high degree of geologic assurance and considered to be economically feasible to mine. Such resources include uranium resources from mines currently in production as well as resources that are in the stages of feasibility or of being permitted. Sources of secondary supply for uranium, such as stockpiles and reprocessed fuel, were also examined. To evaluate longterm primary supply, estimates of uranium from unconventional and from undiscovered resources were analyzed.

At 2010 rates of consumption, uranium resources identified in operating or developing mines would fuel the world nuclear fleet for about 30 years. However, projections currently predict an increase in uranium requirements tied to expansion of nuclear energy worldwide. Under a low-demand scenario, requirements through the period ending in 2035 are about 2.1 million $\mathrm{tU}$. In the low demand case, uranium identified in existing and developing mines is adequate to supply requirements. However, whether or not these identified resources will be developed rapidly enough to provide an uninterrupted fuel supply to expanded nuclear facilities could not be determined. On the basis of a scenario of high demand through 2035, 2.6 million $\mathrm{tU}$ is required and identified resources in operating or developing mines is inadequate. Beyond 2035, when requirements could exceed resources in these developing properties, other sources will need to be developed from less well-assured resources, deposits not yet at the prefeasibility stage, resources that are currently subeconomic, secondary sources, undiscovered conventional resources, and unconventional uranium supplies.

This report's analysis of 141 mines that are operating or are being actively developed identifies 2.7 million $\mathrm{tU}$ of $\mathrm{in}$-situ uranium resources worldwide, approximately 2.1 million $\mathrm{tU}$ recoverable after mining and milling losses were deducted. Sixty-four operating mines report a total of 1.4 million $\mathrm{tU}$ of in-situ RAR (about 1 million $\mathrm{tU}$ recoverable). Seventyseven developing mines/production centers report 1.3 million tU in-situ Reasonably Assured Resources (RAR) (about

${ }^{1}$ U.S. Geological Survey.

${ }^{2}$ U.S. Energy Information Administration.
1.1 million tU recoverable), which have a reasonable chance of producing uranium within 5 years. Most of the production is projected to come from conventional underground or open pit mines as opposed to in-situ leach mines.

Production capacity in operating mines is about $76,000 \mathrm{tU} / \mathrm{yr}$, and in developing mines is estimated at greater than 52,000 tU/yr. Production capacity in operating mines should be considered a maximum as mines seldom produce up to licensed capacity due to operational difficulties. In 2010, worldwide mines operated at 70 percent of licensed capacity, and production has never exceeded 89 percent of capacity. The capacity in developing mines is not always reported. In this study 35 percent of developing mines did not report a target licensed capacity, so estimates of future capacity may be too low.

The Organisation for Economic Co-operation and Development's Nuclear Energy Agency (NEA) and International Atomic Energy Agency (IAEA) estimate an additional 1.4 million $\mathrm{tU}$ economically recoverable resources, beyond that identified in operating or developing mines identified in this report. As well, 0.5 million $\mathrm{tU}$ in subeconomic resources, and 2.3 million $\mathrm{tU}$ in the geologically less certain inferred category are identified worldwide. These agencies estimate 2.2 million tU in secondary sources such as government and commercial stockpiles and re-enriched uranium tails. They also estimate that unconventional uranium supplies (uraniferous phosphate and black shale deposits) may contain up to 7.6 million $\mathrm{tU}$. Although unconventional resources are currently subeconomic, the improvement of extraction techniques or the production of coproducts may make extraction of uranium from these types of deposits profitable. A large undiscovered resource base is reported by these agencies, however this class of resource should be considered speculative and will require intensive exploration programs to adequately define them as mineable. These resources may all contribute to uranium supply that would fuel the world nuclear fleet well beyond that calculated in this report.

Production of resources in both operating and developing uranium mines is subject to uncertainties caused by technical, legal, regulatory, and financial challenges that combined to create long timelines between deposit discovery and mine production. This analysis indicates that mine development is proceeding too slowly to fully meet requirements for an expanded nuclear power reactor fleet in the near future (to 2035), and unless adequate secondary or unconventional resources can be identified, imbalances in supply and demand may occur. 


\section{Introduction}

The Blue Ribbon Commission on America's Nuclear Future was established by President Obama under provisions in the Federal Advisory Committee Act (5 U.S.C. App.2) in 2010 to review and recommend policies for managing spent nuclear fuel from the nuclear power industry. As part of the study, the Commission requested that the EIA assess primary uranium supply globally, and to then compare that supply with world requirements or demands. EIA, in collaboration with the USGS, responded to the request by researching and analyzing the global resource base for uranium. This paper summarizes the results of this analysis, and addresses the question of whether there is sufficient uranium to supply the present or an expanded U.S. nuclear power reactor fleet in the near term ( 25 years), and beyond.

Geologists from the USGS and EIA examined information describing uranium production, resources, and issues related to the continuity of supply of uranium, from all countries that the NEA and the IAEA have identified as containing uranium resources. Reasonably assured resources (RAR), production capacity, and mine life for individual production centers of operating mines and for mines estimated to come online in the near future ( $\sim 5$ to 10 years) were critically examined. Determining long-term supply is more problematic: because projections are based on uranium-containing properties that have not been fully explored, their contained uranium is uncertain. Further uncertainty arises because technical, economic, or political challenges may prevent many such properties from coming into production, even though they are geologically defined. Despite uncertainties, this report uses the best information available in order to explore the potential extent of future supply, as well as the challenges that individual production centers may encounter. Although information about the individual deposits is from the best and most objective sources available, it is beyond the scope of this project for the EIA or USGS to independently verify, through site visits to uranium producers, the accuracy of all the information that the report used as the basis for its analysis.

This report reflects the state of the industry as of December 2011, modified by comments in the narrative that reflect important events that changed the world uranium supply while this paper was in review. It should be noted that the consequences of the recent nuclear accident at the Fukushima Daiichi nuclear plant are not yet fully understood so far as they may relate to the analysis of how the supply of uranium is connected with demand for the metal. To date, the accident has resulted in slightly lower or delayed projected future demand, as in the projection by the World Nuclear Association that nuclear capacity will rise from 393 gigawatts (GW) in 2009 to $630 \mathrm{GW}$ in 2035 , an estimate that is $20 \mathrm{GW}$ lower than the Association projected before Fukushima. Most countries that are members of the OECD, and many non-OECD countries, continue operating existing and developing new nuclear powerplants, albeit delaying such development slightly as they review safety standards for new and for existing plants (World
Nuclear Association, 2011b). Another significant recent development is the suspension of the Olympic Dam mine expansion by BHP Billiton that changes forward supply projections for uranium (ABC News, 2012).

\section{Uranium Supply and Demand Worldwide}

In 2010, there were 442 nuclear powerplants operating worldwide that required 68,646 tonnes of uranium metal $(\mathrm{tU})$, and 53,663 $\mathrm{tU}$ was mined from 16 countries satisfying 78 percent of world requirements (World Nuclear Association, 2011b). Primary sources - active mines that recover uranium as a primary product, a coproduct, or an important byproduct - and a number of secondary sources supply uranium to the world uranium market. Not currently contributing to world uranium supply are unconventional resources, such as uranium in phosphate rocks, in black shale, or in seawater. Although unconventional resources contain a large amount of uranium, the uranium is recoverable only as a minor byproduct.

Secondary sources include (1) stocks and inventories of natural and enriched uranium held in government and in private industry stockpiles, (2) reprocessed spent reactor fuel and recycled plutonium from military sources such as the United States/Russian program in which highly enriched uranium (HEU) is converted to low-enriched uranium (LEU) ("the HEU/LEU program"), and (3) uranium produced from depleted uranium tails. From 1945 through 1991, yearly production outpaced demand by as much as 2.5 times (fig. 2), a mismatch caused by two factors: high levels of uranium mined for military purposes, and a slower growth in the nuclear power industry than had been expected (NEA-IAEA, 2010).

\section{Uranium Supply Worldwide}

\section{Primary Sources}

The long-term operation of nuclear powerplants and the expansion of a nation's capacity for producing nuclear power depend on the development of uranium from primary sources. Yellowcake, or uranium oxide $\left(\mathrm{U}_{3} \mathrm{O}_{8}\right)$, is the primary product of uranium mining, and the price of yellowcake hinges on world demand. Increases in uranium price encourage exploration for primary resources, thereby increasing supply. Mineability of an individual deposit is influenced by the delineation of identified RAR, the duration of the permitting process, the costs to mine and mill the product, the construction of infrastructure, and the ability of mine owners to raise capital to finance mining projects. Current estimates show the lag time from discovery to production ranges from 15 to 20 years (Vance, 2005; Boytsov, 2010) (fig. 3). When researchers attempt to determine world uranium supplies that will be available in the future, the length of this lag time makes it necessary to look at projects that are in early stages of development. 


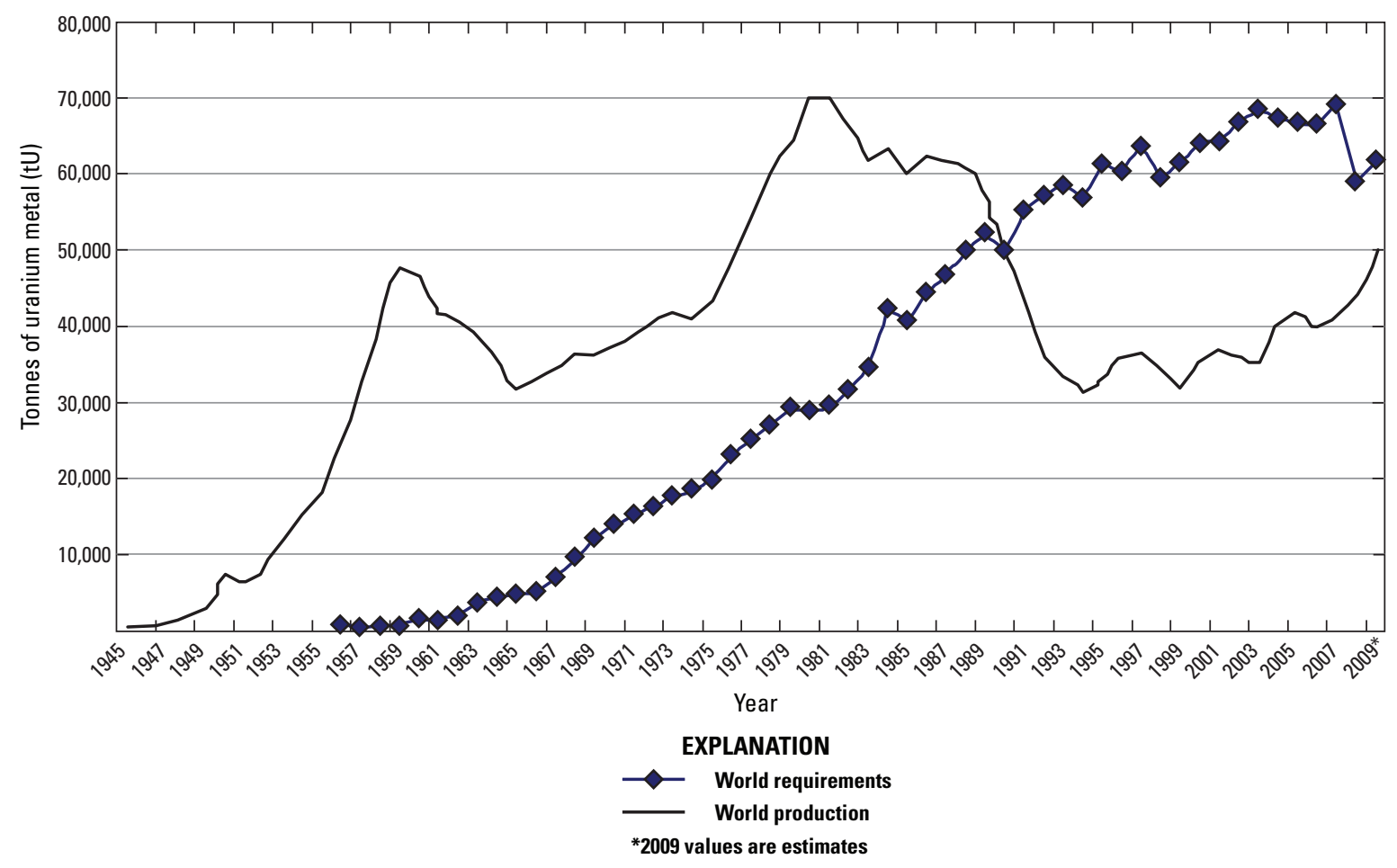

Figure 2. Historic uranium production and nuclear powerplant requirements, 1945-2009. From NEA-IAEA (2010), reproduced with permission.

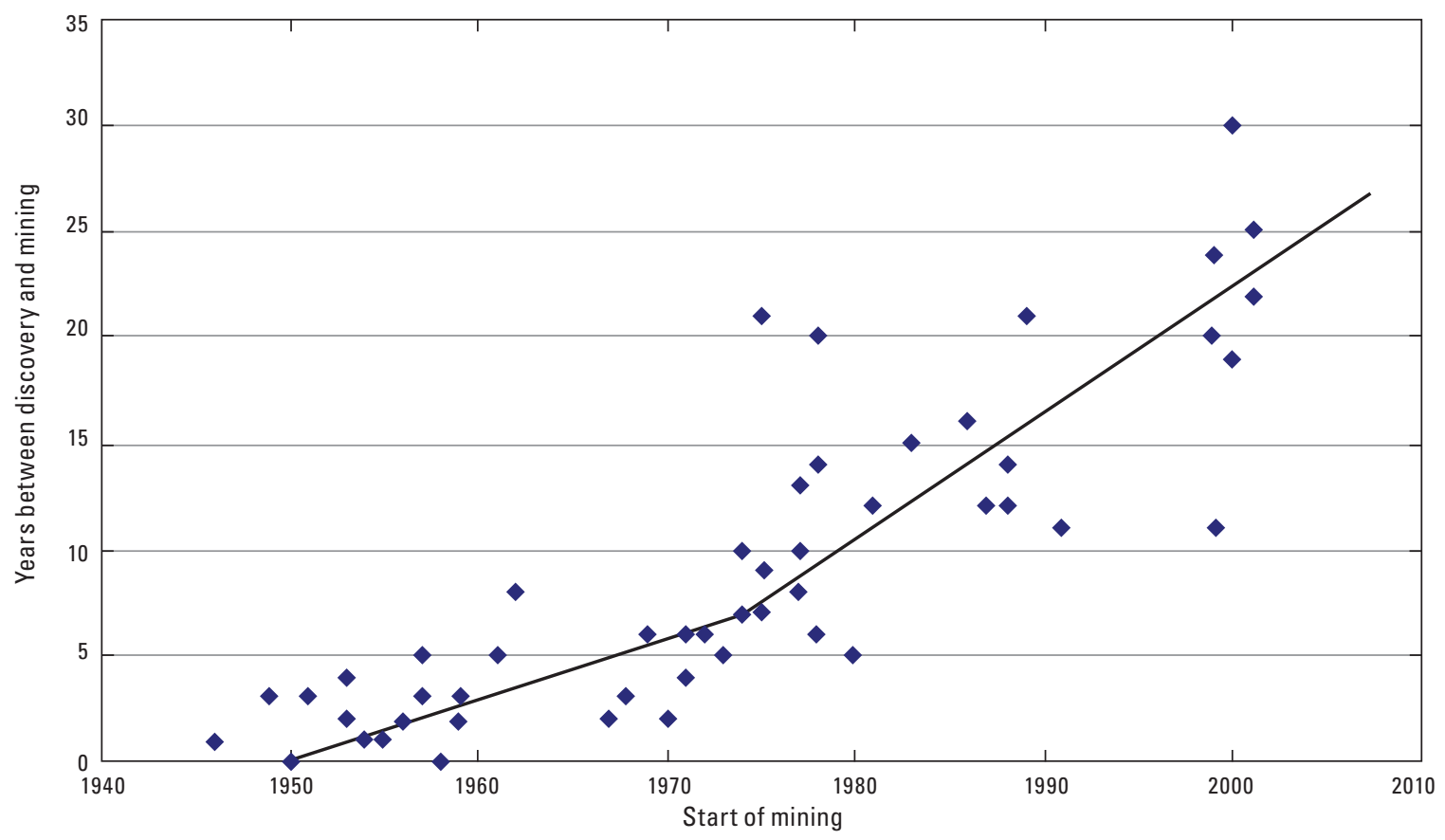

Figure 3. Elapsed time between discovery of a uranium mine and the start of mining, for all mining methods. From NEA-IAEA (2010), reproduced with permission. 


\section{Identification of Primary Sources}

The development of uranium supply begins when new uranium-producing properties are identified. An analysis of expenditures for exploration provides a measure of the effort being expended to identify new resources and to bring supply online. Since 1975, exploration expenditures increased rapidly until 1980, then increased at a more gradual rate through 2006, when a rise in the price of uranium preceded a rapid infusion of exploration expenditures. Increases in RAR followed the increase in exploration activities as measured by exploration expenditures (fig. 4).

Most uranium mining districts were originally identified by mineralization of uranium that was exposed at the surface, producing a geochemical and (or) geophysical anomaly. Studying the geology of these exposed deposits enabled geologists to identify concealed deposits in the same local environment. Identifying deposits having no such surface expression may in the future require more resources, including time, to delineate these targets than did deposits discovered in the past.

At the reconnaissance scale, conventional geophysical and geochemical techniques have been used to identifying concealed uranium deposits with mixed success. Radon, a uranium-decay product, has been analyzed on surfaces above potential deposits, but because this decay product is short lived and relatively mobile anomalies do not always directly identify mineralization. Geochemical analysis of groundwater has been used successfully in locating deposits which do not crop out. Some geophysical surveys effectively target units that commonly contain uranium mineralization, such as conductive shale units in the Athabasca basin (Saskatchewan, Canada) that can then be explored by drill testing. Recently, variable time-domain electromagnetic techniques have identified uranium breccia-type deposits in Arizona (Spiering and others, 2009).

Deposit-scale geophysical techniques have proved more successful. It is now possible to directly measure $\mathrm{U}^{235}$ using Prompt Fission Neutron technology, which is being used in lieu of indirect measurement of $\mathrm{U}^{235}$ by interpretation of gamma profiles. However, at the reconnaissance scale this technique is of limited use in identifying concealed deposits. If better techniques to identify concealed deposits are developed, it is likely that more uranium supply could be identified.

\section{Costs of Uranium as a Fuel}

The cost of uranium fuel for generating electricity is low when compared to the costs of other types of fuel. Although finding accurate figures is difficult, the price of yellowcake is estimated to contribute only about 25 percent to the total cost of nuclear fuel, the rest being attributable to processing (conversion, enrichment, and fabrication). At 60 U.S. dollars (USD) per pound of uranium oxide $\left(\mathrm{U}_{3} \mathrm{O}_{8}\right)$, (equivalent to USD 155 per kilogram contained uranium metal (USD 155/kgU)), nuclear fuel costs less than 0.7 cents

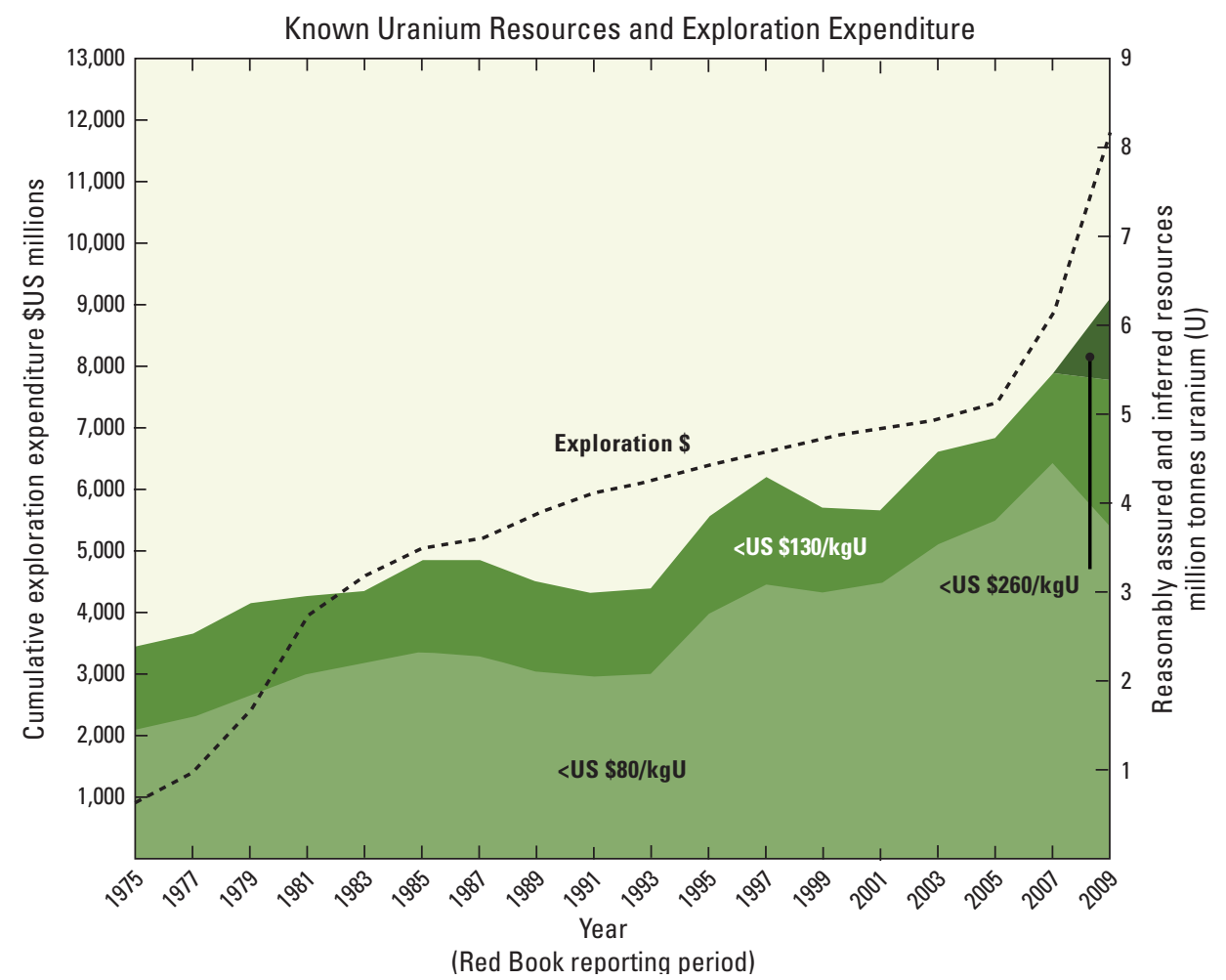

Figure 4. Uranium exploration expenditures and resources identified during 1975-2009. From World Nuclear Association (2011b), reproduced with permission. 
per kilowatt-hour $(\mathrm{kWh})$ of electricity, or on average about 4 to 6 percent of the retail price of electricity (MIT Energy Initiative, 2011). This low relative fuel cost makes it easier for utilities to absorb increases in uranium price than to absorb price increases for more costly fuels that generate electricity. MIT estimates that utilities can absorb the uranium costs of USD 300 to USD 400/kgU for light water reactors. This would increase lifetime-levelized costs (busbar costs) for nuclear reactors by 8 to 12 percent (MIT Energy Initiative, 2011). If uranium prices doubled, an estimated 479,000 tU of RAR of uranium in deposits that are now subeconomic would potentially become economic.

\section{Contractual Categories for Purchasing Uranium}

Worldwide uranium purchases fall into two categories: spot purchases (delivery within one year), and contracts (medium- and long-term delivery). These prices have traditionally tracked each other fairly closely, with the exception of the time period of 2006 to 2009 when market forces caused the prices to decouple (fig. 5). While waiting for sale or delivery, $\mathrm{U}_{3} \mathrm{O}_{8}$ (uranium as yellowcake) can be held only at producers' sites or at conversion sites.

Long-term contracts are those in which utilities contract with a supplier, most commonly a corporation owning an active mine, to supply their uranium needs for generating electricity. These contracts are typically at a fixed price, with provisions for fluctuations in market price and demand, and they run for many years. The duration of long-term contracts depends upon where the buyer is physically situated. In the United States, contracts typically run for 5 years; in Europe, 10 years; and in Japan, typically 15 years. For price indicators, the industry relies on market research because these contracts are generally not publicly available; the exception being contracts in European Union countries which are reviewed by the EURATOM Supply Agency. The Ux Consulting Company LLC. (http://www.uxc.com), TradeTech (http://www.uranium.info/) and the Euratom Supply Agency (http://ec.europa.eu/euratom/) all track uranium prices.

The short-term "spot" price (available for delivery in a short time frame (3-12 months)) of uranium is a smaller market in total volume. In 2011, the volume of uranium in the spot market was about $16,000 \mathrm{tU}$, or 20 percent of demand, and 30 percent of production, a ratio similar to that in the 1990s (TradeTech, 2011; Ux Consulting Company LLC, 2011). Uranium ends up on the spot market from smaller mines that cannot supply the quantities of uranium over timeframes that utilities require, or as a speculative product, with intermediaries buying uranium and holding it in hopes of receiving a higher price in due time. Uranium can also end up on the spot market in special circumstances, such as those of the U.S. Department of Energy, which is currently selling U.S. uranium stockpiles to help meet its costs of environmental cleanup at the Portsmouth, Ohio enrichment facility. Buyers on the spot market can be utilities, producers, or intermediaries, the uranium being either used in reactors or being resold.

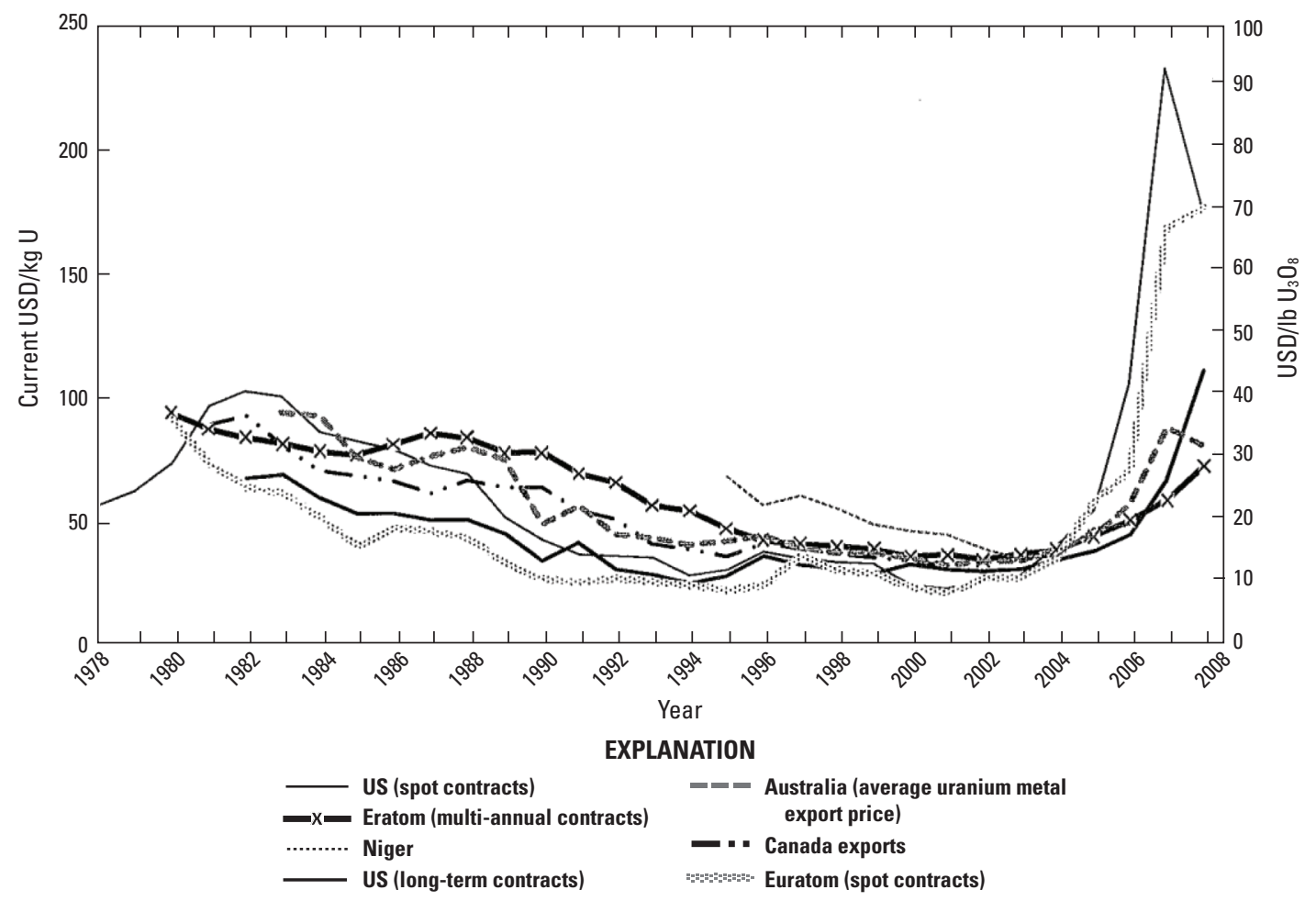

Figure 5. Uranium prices in U.S. dollars per pound of uranium oxide $\left(\mathrm{U}_{3} \mathrm{O}_{8}\right)$, by type of contract, by major buyers, 1978-2009. From NEA-IAEA (2010), reproduced with permission. 
Producers, traders, and even utilities at times may all contribute to the spot market. Key traders are NUKEM BMbH (and NUKEM Inc.), Urangelsellschaft mbH, INTERNEXCO $\mathrm{GmbH}$, Marubeni Corporation, Traxys North America LLC, ITOCHU Corporation, Nufcor International Ltd.(Goldman Sachs) and the Mitsui Corporation. Some producers, such as the Cameco Corporation (Cameco), also participate in the spot market. Brokers seek out uranium and place it for a commission, including American Fuel Resources, ICAP, MF Global, the New York Nuclear Corporation, and Evolution Markets. Hedge fund managers and investor funds have become attracted to the spot uranium market, running up prices to a recent high price of USD 136/lb. $\mathrm{U}_{3} \mathrm{O}_{8}$ (USD 353/kgU) in July 2007. This kind of investing decoupled spot and longterm prices to such an extent that the spot price now responds equally rapidly to perceived and to real threats to uranium supply. For this reason, short-term prices may not be the best indicator of the cost of nuclear fuel, which more closely tracks long-term contract prices.

\section{Secondary Sources}

Secondary sources are likely to become increasingly important for meeting uranium demand over the longer term. Projections to 2020 predict that the contribution from secondary supplies will shrink, while primary supply, mainly from mines in Africa, Kazakhstan, Australia and Canada, increases. (figs. 6, 7) (Ux Consulting Company LLC, 2010).

The more important secondary sources, the uranium that may be included in these resources and supply challenges are described below. Although secondary uranium sources are an important portion of the total world uranium supply, the quantity of uranium contained in these sources is difficult to quantify. Most countries do not report stockpiles of uranium, the concentration of uranium in depleted uranium tails is not well quantified, nor is information about the use of tails readily available, and the future disposition of Russian HEU is unknown.

Stockpiles.-From 1945 through 2008, NEA estimates that 2,415,000 tU were produced and that 1,840,000 tU were consumed, with the surplus production of 575,000 tU remaining in stockpiles (NEA-IAEA, 2010). However, the amount of this material that could become available to the market is not well known, since only limited information on the size of world stockpiles of uranium is publicly available.

HEU to LEU.-Programs that reduce HEU (highly enriched uranium) to LEU (low enriched uranium) ("HEU to LEU") are another secondary uranium source. In the United States, the Megatons to Megawatts program, a government-industry partnership in which Russian-origin HEU is downblended for use in nuclear power plants, is expected to end in 2013 , reducing the supply of secondary uranium by an estimated 9,200 tU/yr. To date, this program is estimated to have recycled more than 400 metric tons of HEU into 11,905 tU of LEU for use in U.S. nuclear powerplants (U.S. Enrichment Corporation, 2011).

Re-enriched Tails.—Depleted uranium tails are a byproduct of the uranium enrichment process. NEA (2010) estimates that $1,600,000$ metric tonnes is contained in uranium tails worldwide, at an average concentration between 0.25 and 0.35 percent $U$. This grade is similar to uranium grades in mines that are economically extracting uranium from sandstone-hosted uranium deposits. NEA estimates that, if this entire inventory were re-enriched, 450,000 tU would be produced, the equivalent of more than 7 years of consumption at 2010 levels. However, this enrichment requires commercial capacity that is currently not available for enrichment and that only high uranium prices could sustain.

MOX and RepU.-Mixed oxide fuel (MOX) and reprocessed uranium (RepU) are expected to become increasingly important secondary sources of supply in the future. MOX and RepU originate from reprocessing spent nuclear fuel. Uranium and plutonium are recovered by reprocessing, and can then be used in nuclear power plants. The use of RepU fuel is tied to uranium costs; when mined uranium carries higher costs, reprocessed fuel becomes more attractive. MOX fuel is widely used in reactors in Japan and Europe. Fifty reactors worldwide are licensed to use MOX fuel, although not all of them are using this fuel type (World Nuclear Association, 2011b).

\section{Unconventional Resources}

Uranium recoverable only as a mining byproduct is termed an "unconventional" uranium resource. The contribution of uranium from unconventional resources could be an important source in the future. Uranium in phosphate-rich rocks, in black shales, in lignite, and in seawater are considered unconventional resources.

Phosphates have historically been a source of market supply of uranium and are a potential source of uranium in the future. Prior to December 2011 an estimated 57,863 tU was produced from phosphate deposits in Kazakhstan, the United States and Morocco (NEA-IAEA, 2010). Production costs higher than the market value of uranium have slowed development of this supply. However, recent technical innovations that hold the promise of more cost-effective production of uranium from phosphate deposits have prompted industry investment into developing this resource (Jones and others, 2009; World Nuclear News, 2007). Cameco invested in and is testing the effectiveness of the PhosEnergy process developed to extract uranium from phosphate rock (Ux Consulting Company LLC, 2010). Uranium in phosphate rocks is estimated to contain a resource greater than 7.9 million tU with 
World Uranium Supply 2010

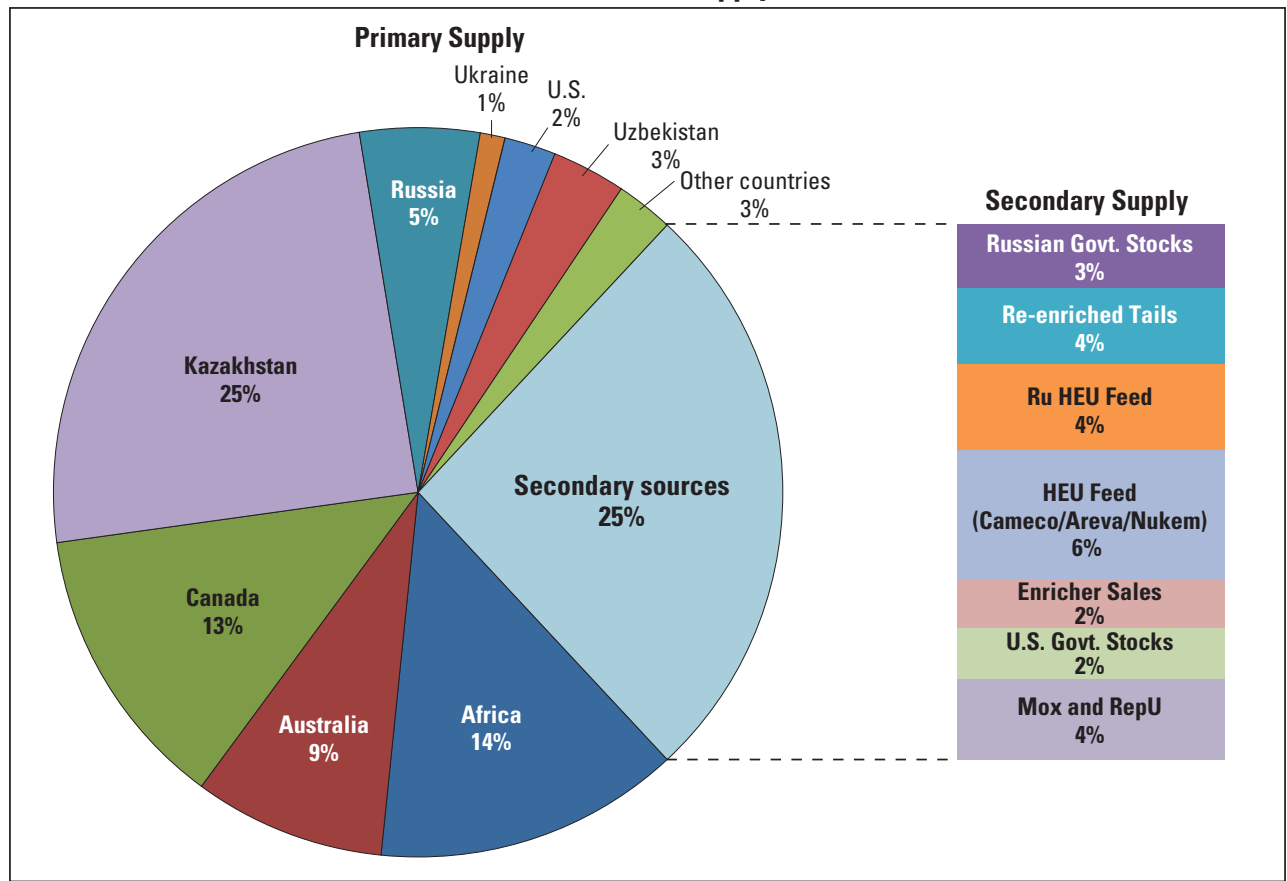

Figure 6. World uranium supply distribution, 2010. Data from Ux Consulting Company LLC ( 2010).

World Uranium Production Projection in 2020

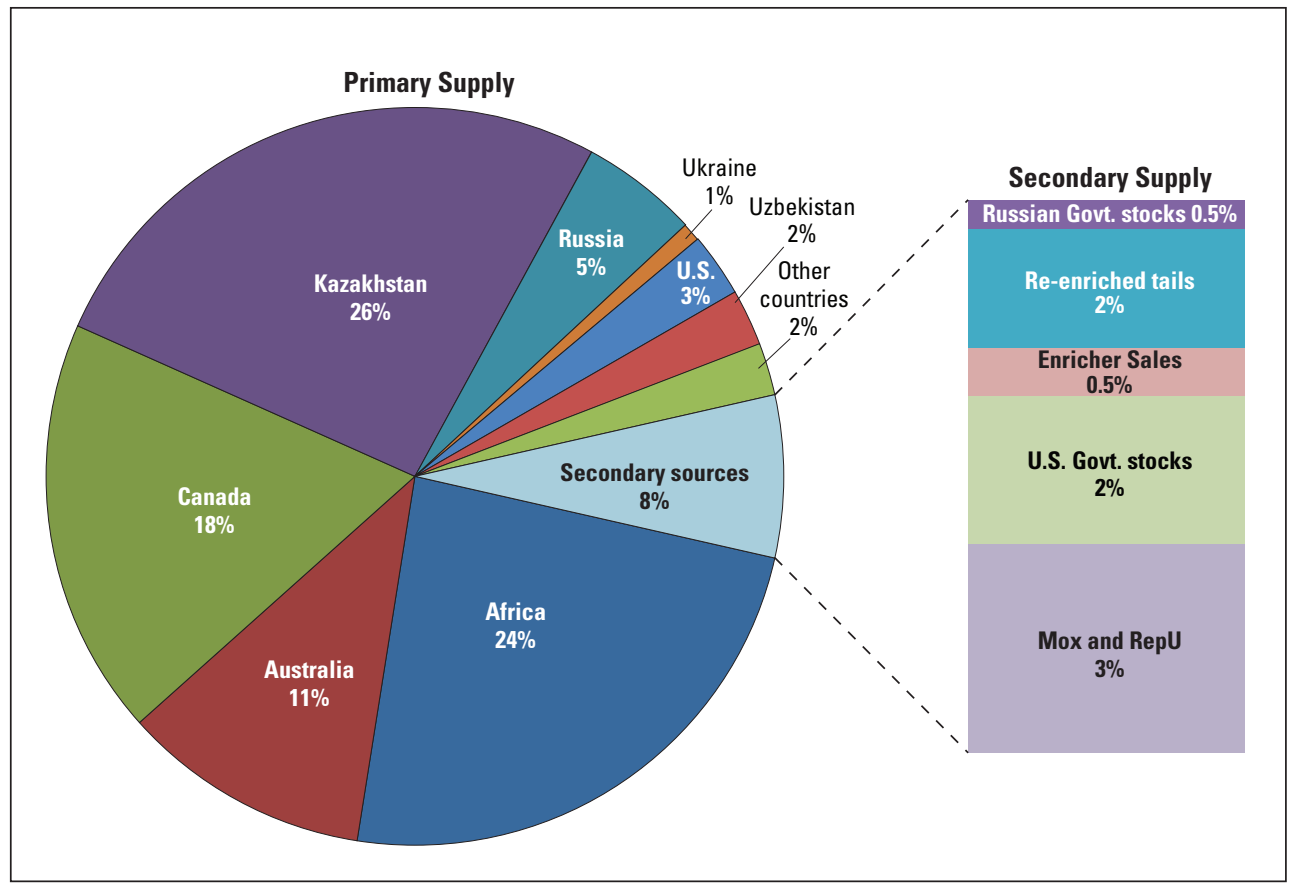

Figure 7. Contribution of primary and secondary uranium sources worldwide, projected to 2020. Data from Ux Consulting Company LLC (2010). 
an average ore grade that ranges from 0.006 percent $U$ to 0.053 percent U (IAEA, 2010). Uranium rich phosphate deposits are identified in Morocco, the United States (Florida and Idaho), Jordan, Egypt, Iran, Iraq, Mexico, Kazakhstan, Sweden, Syria, Israel, Brazil, Finland, and Greece (IAEA, 2010). Pilot projects exploring uranium extraction from phosphate deposits are underway in the United States, Brazil, and Jordan.

An estimated 1.3 million $\mathrm{tU}$ worldwide is contained in black shale and in lignite deposits (IAEA, 2010). The uranium in these deposits is low-grade ( 0.01 to 0.17 percent $\mathrm{U}$ ) and requires production of another commodity to support extraction of the uranium (IAEA, 2010). The largest uraniumrich black shale deposits are in Sweden and Germany, with deposits also identified in Uzbekistan, Korea, China, Canada, Poland, Turkmenistan, Finland, Uzbekistan, Poland, and France. Uraniferous lignites are identified in South Africa, Kazakhstan, Russia, Spain, the United States, Australia, Greece, Germany, Kyrgyzstan, and the Czech Republic. Uranium has been mined from black shales in the past in Sweden. The Talvivaara polymetallic black shale deposit in Finland, currently being mined for nickel and zinc, also contains an estimated 17,110 tU. Cameco is financing the construction of a circuit to recover uranium from this resource, targeting a production rate of $350 \mathrm{tU} / \mathrm{yr}$ (Ux Consulting Company LLC, 2010).

Research to develop cost-effective techniques to recover uranium from seawater has been carried out in Germany, Italy, Japan, the United States, and the United Kingdom. The current focus of research is the development of specialized polymer braids moored on the ocean floor. Recovery costs for a largescale system that would recover $1200 \mathrm{tU} / \mathrm{yr}$ are estimated to be about USD 700/kgU (Hisatani, 2010; NEA-IAEA, 2010), which would be uneconomic at current and anticipated prices of uranium.

\section{Current World and U.S. Production}

World uranium production in 2010 was 53,663 tU, up from 50,772 tU in 2009 (World Nuclear Association, 2009; NEA-IAEA, 2010). Global production has increased gradually since the early 1990s, after steadily declining for 13 years (1980-93). Six countries currently dominate world production and are expected to produce 83 percent of uranium concentrate during the 10 years until 2020: Kazakhstan, Canada, Australia, Namibia, Russia, and Niger (Ux Consulting Company LLC, 2010). The three largest producers - Kazakhstan, Canada, and Australia - account for 63 percent of the world production of uranium concentrate (World Nuclear Association, 2009). Kazakhstan dramatically increased uranium production from $2,022 \mathrm{tU}$ in 2001 to $19,450 \mathrm{tU}$ in 2011, although projections indicate peak production capacity may have been reached (World Nuclear Association, 2011b).

The United States currently produces about 3 percent of the world uranium concentrate (NEA-IAEA, 2010), with 4.2 million pounds $\mathrm{U}_{3} \mathrm{O}_{8}(1,629 \mathrm{tU})$ in 2010 from one mill (White Mesa Mill) and from four in-situ leaching (ISL) plants (Alta Mesa Project, Crow Butte Operation, La Palangana, and Smith Ranch-Highland Operation) (Energy Information Administration, 2010a).

Domestic and world uranium production and exploration has historically responded to market conditions. For example, U.S. production of uranium concentrate peaked in 1980 at more than 43 million pounds of $\mathrm{U}_{3} \mathrm{O}_{8}(16,810 \mathrm{tU})$, as a prolonged period of rising prices and intensive exploration ended (fig. 8). By 1980, production exceeded reactor requirements, creating a surplus of uranium. During 1981-2003, domestic uranium production declined to a low of 2 million pounds of $\mathrm{U}_{3} \mathrm{O}_{8}$ (769 tU), coinciding with a nearly 20 -year period of falling prices (1981-2000). Prices began to rise in 2000, with significant increases during 2003-2007. Increases in the spot price of

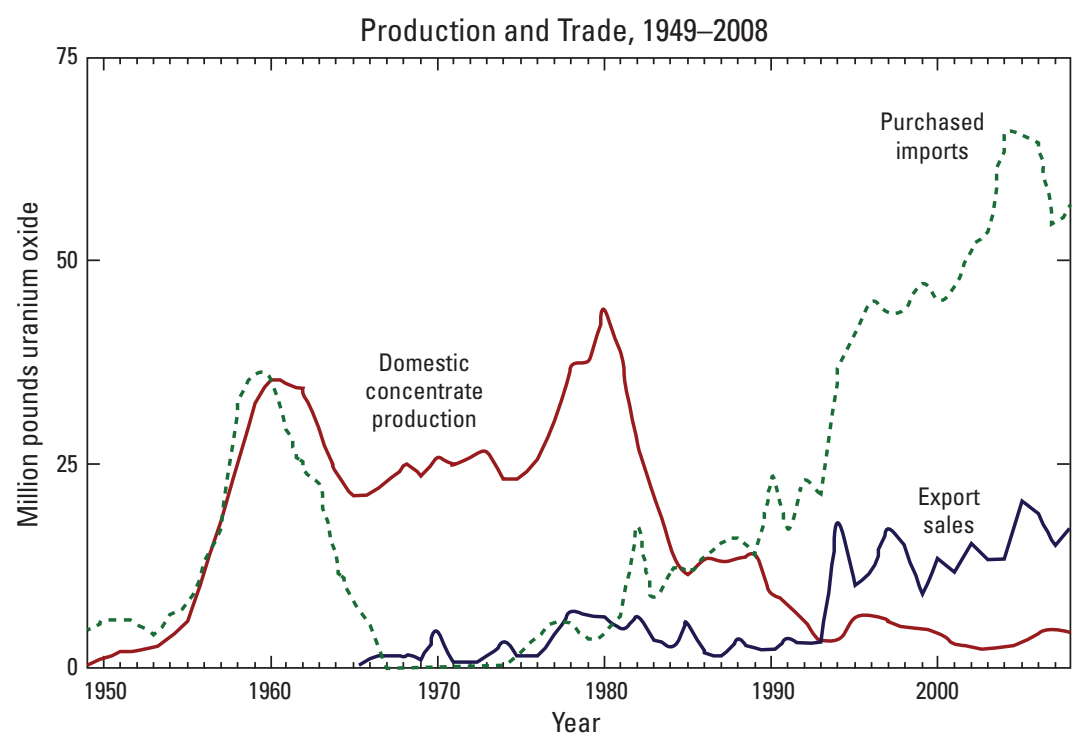

Figure 8. U.S. production, purchases, and sales of uranium, 1949-2008 (Energy Information Administration, 2010b). 
uranium during 2000-2007 were attributed to a combination of market factors: the increasing prospects for nuclear powerplant construction, declining inventories, temporary difficulties at existing and developing mines and mills, and the entry of speculators into the uranium market (Nuclear Energy Agency, 2008). U.S. production also steadily increased from less than 2 million pounds ( $769 \mathrm{tU})$ in 2003 to more than 4.5 million pounds of $\mathrm{U}_{3} \mathrm{O}_{8}(1,730 \mathrm{tU})$ in 2007, following the increase in spot prices. Uranium prices reached a high of USD 136/lbU $\mathrm{O}_{8}$ (USD 353/kgU) in spring 2007, followed by a drop to prices ranging from USD 40 to USD 55 during the three years 2008-2011, as a rapid expansion of production in Kazakhstan. Other market factors, such as the global financial crisis, added obstacles to financing uranium exploration, mine development, and construction of nuclear power plants, all of which contributed to the "cooling" of the uranium market. Prices surged again during the last quarter of 2010 and in early 2011, in response to China's announced plans for and its moves to secure uranium contracts for large planned increases in nuclear power. Sustained higher prices would most likely stimulate uranium exploration and production, although permitting of new and expanded mines continues to be challenging.

\section{Uranium Demand Worldwide}

The only uranium requirements that this analysis considers are those necessary for the generation of electricity by civilian nuclear powerplants. Military and other government requirements are not included. Growth in world generation of electricity has outpaced growth in total consumption of energy during the 20-year period, 1991-2011; this trend is expected to continue for generating electric power through 2035 (Energy Information Administration, 2010b). Nuclear power accounts for about 14 percent of worldwide and 20 percent of domestic U.S. generation of electricity (Energy Information Administration, 2010b). Although electricity generated by nuclear power is expected to increase by about 2 percent a year for the 25 years through 2035 , the relative contribution of nuclear energy to the generation of electricity is expected to stay the same (Energy Information Administration, 2010b) (fig. 9).

\section{Current World Uranium Demand}

In 2010, the world demand for uranium to power commercial reactors for electricity generation was $68,646 \mathrm{tU}$, as measured from acquisitions of uranium resources (World Nuclear Association, 2011b). The total acquired uranium for nuclear power is not an exact measure of the amount of uranium actually loaded into reactors; it may be higher or lower than the amount used for power generation, depending on the amount used from inventories (World Nuclear Association, 2011a).

\section{Current U.S. Uranium Demand}

In 2009, owners and operators of U.S. civilian nuclear reactors purchased a total of 50 million pounds of $\mathrm{U}_{3} \mathrm{O}_{8}$ $(19,232 \mathrm{tU})$ (Energy Information Administration, 2009). Following recent trends, most uranium purchased in the United States in 2009 ( 86 percent) originated from foreign producers, while 14 percent originated from U.S. mining operations (fig. 10). In 2009, uranium in U.S. nuclear reactors originated

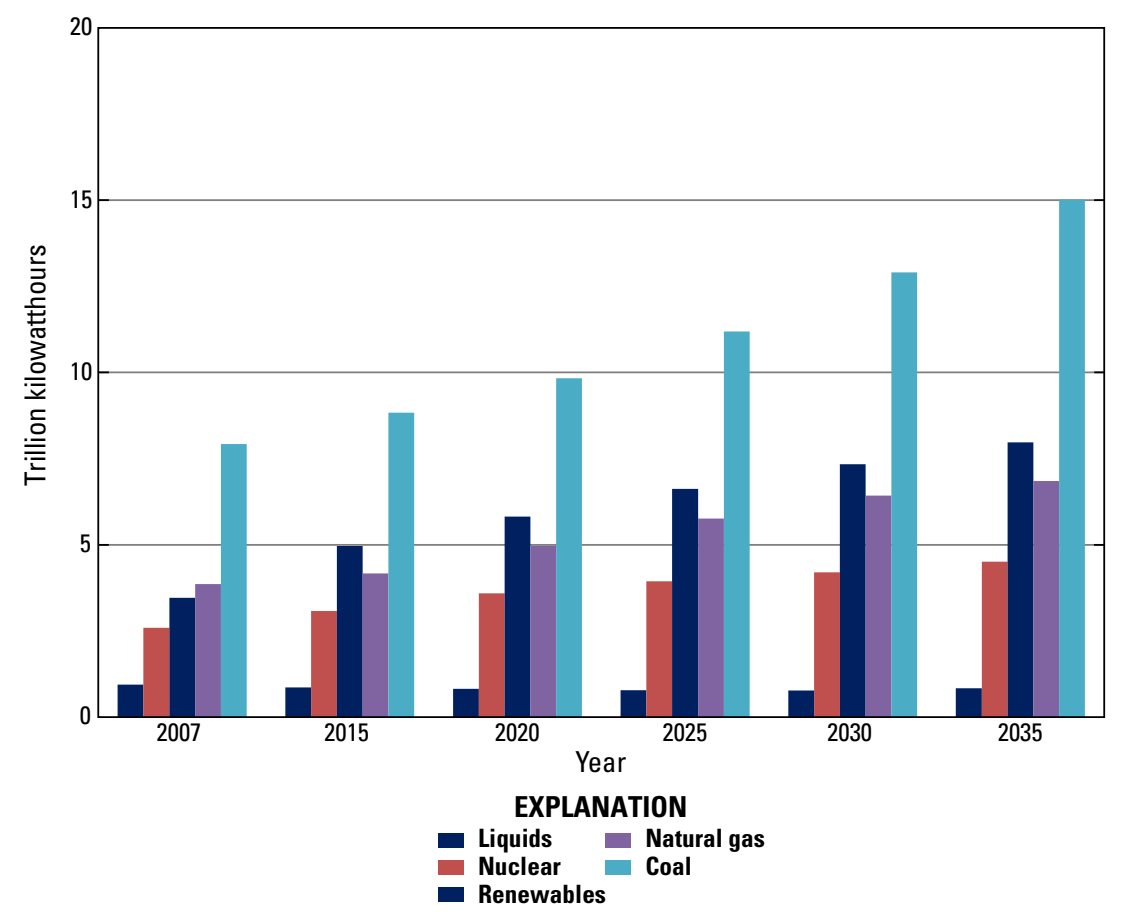

Figure 9. Net generation of electricity worldwide, in trillions of kilowatt hours, by all fuels, 2007-2035 (Energy Information Administration, 2010c). 


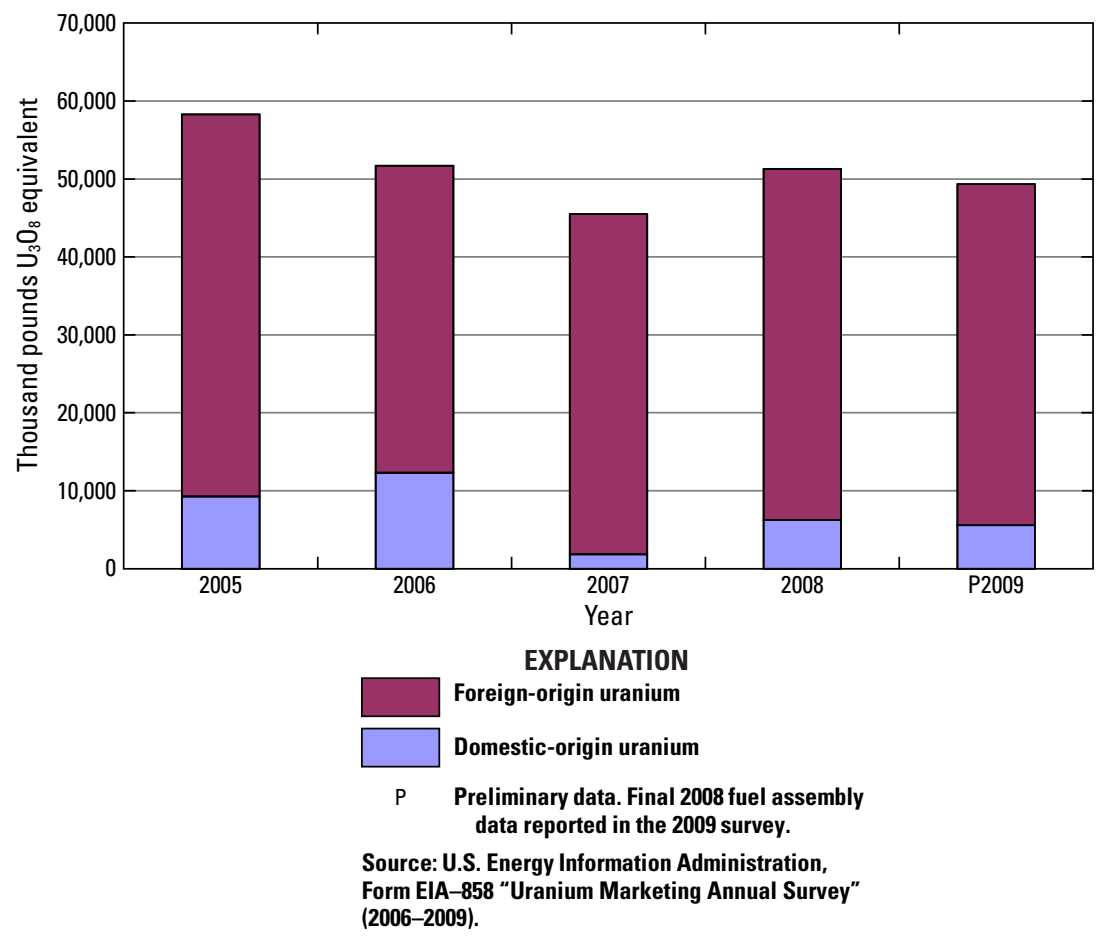

Figure 10. Uranium in fuel assemblies, in thousand pounds of uranium oxide equivalent loaded into U.S. civilian nuclear power reactors, by originating source, by year, 2005-2009 (Energy Information Administration, 2010d).

from Australia and Canada (40 percent); Kazakhstan, Russia, and Uzbekistan (29 percent); and Brazil, Czech Republic, Namibia, Niger, and South Africa (17 percent) (Energy Information Administration, 2010d) (fig. 11).

\section{Current U.S. Uranium Inventory}

The commercial inventory of uranium owned by U.S. civilian nuclear powerplant owners and operators totaled 84 million pounds $\mathrm{U}_{3} \mathrm{O}_{8}(32,310 \mathrm{tU})$ by 2009 year end. Commercial inventory includes ownership of uranium in various stages of the fuel cycle at domestic and foreign facilities. The total U.S. commercial inventory including inventories owned by brokers, converters, enrichers, fabricators, producers, and traders, was 110 million pounds $\mathrm{U}_{3} \mathrm{O}_{8}(42,311 \mathrm{tU})$ at the end of 2009 (Energy Information Administration, 2010d). In addition to their existing inventories, owners of nuclear powerplants have contracts in place for uranium for which EIA collects data 10 years into the future. At the end of 2009, commercial plants had purchase contracts in place for a total of 261 million pounds of $\left.\mathrm{U}_{3} \mathrm{O}_{8}(100,392 \mathrm{tU})\right)$ under purchase contracts during 2010-2019. The maximum anticipated market requirement, for commercial plant owners alone, during 2010-2019, totals 503.4 million pounds $\mathrm{U}_{3} \mathrm{O}_{8}(193,477 \mathrm{tU})$ (Energy Information Administration, 2010d) (fig. 12). Note that "market requirement" is not the same as "commercial reactor requirement," although the numbers are not significantly different ( $\sim 50$ million pounds $\mathrm{U}_{3} \mathrm{O}_{8},(19,232 \mathrm{tU})$ per year loaded into U.S. commercial reactors).

\section{Projected Future Uranium Supply and Demand}

\section{Growth in Demand}

Projections of future uranium demand depend on predictions of nuclear generating capacity, and on the type of reactors and fuel being used to generate electricity. EIA forecasts that electricity generation from nuclear power worldwide will increase from 2.6 trillion kilowatt-hours in 2007 to 4.5 trillion kilowatt-hours in 2035. Global concerns about greenhouse gases, rising fossil-fuel prices, the need for additional energy in developing countries and energy security support the development of additional nuclear capacity. However significant challenges and uncertainties remain, including unresolved issues of storage and disposal of nuclear waste, concerns about the safety of nuclear power, and the large capital costs associated with powerplant construction. These major concerns continue to prevent significant growth of nuclear power in many member countries of the OECD. Several nonmember countries, most notably China, are forging ahead with construction of new powerplants, and they maintain ambitious goals for adding significant new capacity during the 25 years to 2035. In the longer term, the expansion of the use of MOX and RepU fuels, and the development of Generation IV reactors, with their lower fuel requirements, will also influence demand. 


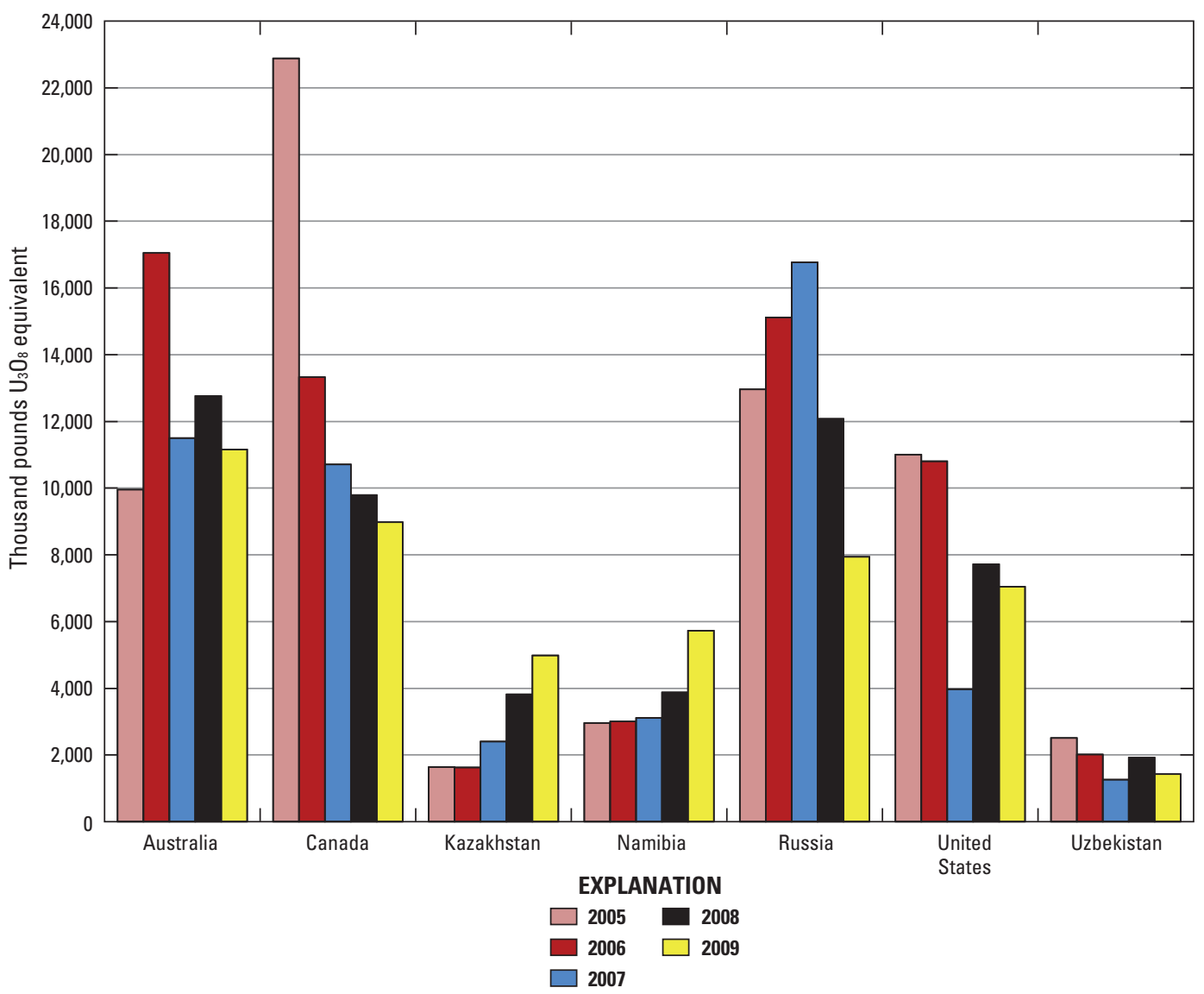

Figure 11. Uranium purchased by owners and operators of U.S. civilian nuclear power reactors, by selected country of origin and by delivery year, 2005-2009 (Energy Information Administration, 2010d).

Short-term projections are made with a fair amount of certainty, because most near-term capacity is already in operation. Longer term forecasts, to 2035, 2050, and 2100, are subject to much greater uncertainties. The growth of nuclear capacity in a given country depends on economics, which are difficult to predict, and on legislation and regulations that are subject to change. In any case, most scenarios point to future growth. To account for the uncertainties, the following projections consider both low- and high-case scenarios.

\section{Growth in Supply}

In order to assess with some certainty the issues of uranium supply in the near future ( $\sim 10$ years), this study evaluates individual deposits and aggregates these results to determine longer-range trends. Beyond 10 years, development is much more uncertain. The NEA and the IAEA jointly prepare the biennial publication "Uranium 20XX: Resources, Production and Demand," also known as the "Red Book" for its distinctive red cover. For this report, published studies of long-term supply were critically examined, and resources from the "Red Book" were used to estimate long-term uranium supply (NEA-IAEA, 2010).

Tables 1-4 and appendix 1 provide detailed summaries of operating uranium mines and of properties that are likely to be producing uranium in the near future. No single published source exists for the tonnage of remaining RAR within operating mines, and so this paper examined each deposit using best estimates. Sources for the report's information are presented in tables 1-4. Some countries, such as India and Iran, are not expected to produce uranium that will be sold on the open market, but this report evaluated the RAR within these countries and included those data in its totals for comparing worldwide uranium supply to demand.

Production capacity is reported for mines where available. No mine operates at its maximum-rated capacity for the entire mine life, and so readers should consider the stated capacity to be a guideline, useful in terms of estimating shortterm supply only. A production center can process ore from several mines, as the White Mesa Mill in Utah processes ore from the Arizona One mine and from Colorado's Pandora and Daneros mines. Alternatively, a production center may represent an ISL mine that produces yellowcake from each individual mine as a final product without offsite milling. Production facilities, usually uranium mill sites for conventional mining, and the mines that supply ore to these facilities, were crosschecked to avoid over reporting of capacity. In some cases, data were unclear when describing which production facilities were supplied by which mines. As well, reports of RAR may not be accompanied by data on the proposed capacity for these mines. 
2009 Uranium Marketing Annual Report

Release Date: August 18, 2010

Next Release Date: May 2011

Maximum Anticipated Uranium Market Requirements of Owners and Operators of U.S. Civilian Nuclear Power Reactors, 2010-2019, as of December 31, 2009

(Thousand Pounds $\mathrm{U}_{3} \mathrm{O}_{8}$ Equivalent)

\begin{tabular}{|c|c|c|c|c|}
\hline Year & $\begin{array}{c}\text { Maximum Under } \\
\text { Purchase Contracts }\end{array}$ & $\begin{array}{c}\text { Unfilled Market } \\
\text { Requirements }\end{array}$ & $\begin{array}{c}\text { Maximum Anticipated } \\
\text { Market Requirements }\end{array}$ & $\begin{array}{c}\text { Enrichment Feed } \\
\text { Deliveries }\end{array}$ \\
\hline 2010 & 40,739 & 4,425 & 45,164 & 47,567 \\
\hline 2011 & 39,836 & 5,688 & 45,523 & 49,621 \\
\hline 2012 & 36,296 & 15,342 & 51,638 & 52,712 \\
\hline 2013 & 34,846 & 16,988 & 51,834 & 45,712 \\
\hline 2014 & 31,025 & 17,725 & 48,749 & 52,020 \\
\hline 2015 & 25,691 & 26,892 & 52,583 & 53,686 \\
\hline 2016 & 20,004 & 32,238 & 52,242 & \\
\hline 2017 & 14,722 & 34,113 & 48,834 & 51,217 \\
\hline 2018 & 10,863 & 44,661 & 55,525 & \\
\hline 2019 & 6,961 & 44,374 & 51,334 & 5 \\
\hline
\end{tabular}

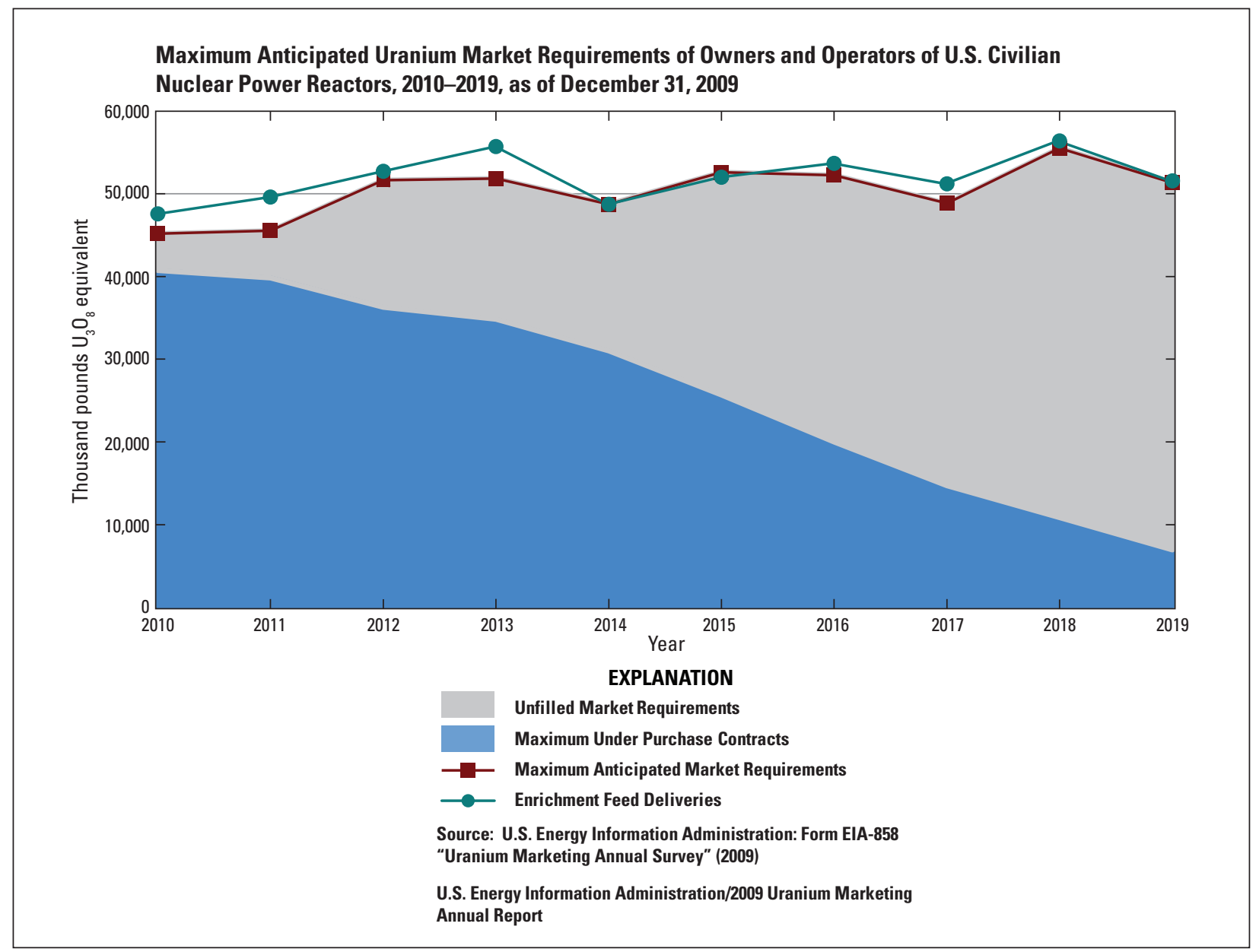

Figure 12. Maximum anticipated uranium market requirements of owners and operators of U.S. civilian nuclear power reactors, 2010-2019, as of December 31, 2009 (Energy Information Administration, 2010d). 
Beyond fact-checking of RAR, of capacity, and of mine life, country narratives explore potential interruptions to supply based on technical, economic, or political challenges for individual deposits or for political provinces (appendix 1). In these narratives the term "in the near future" describes a development scenario that is ten to fifteen years into the future. This timeframe roughly corresponds to the time it takes to develop a uranium deposit into a producing mine and, in some cases, to develop mining regulations within countries where such regulations do not exist.

\section{Identified Resources}

\section{Short-term Supply}

An analysis of producing mines (operating mines and developing mines) completed for this report identifies 2.7 million $\mathrm{tU}$ of in-situ RAR (2.1 million tU estimated recoverable) in 64 operating and in 77 developing mines worldwide (tables 1-4). The operating mines/production centers report a total of 1.4 million tU of in-situ RAR (table 3), approximately 1 million tU of which are estimated to be recoverable (table 2, Developing mines report 1.3 million $\mathrm{tU}$ in-situ RAR (1.1 million $\mathrm{tU}$ estimated recoverable), which have a reasonable chance of producing uranium within 5 to 10 years (table 3 ). This report applies mining and milling to in-situ resources, following NEA/IAEA guidelines (NEA-IAEA, 2010). In ambiguous mining and resource scenarios, this report used conservative mining and milling losses, and so the resulting recoverable resources should be considered minimums. Because actual recovery is unknown until mining is complete, these are rough estimates to be used for planning purposes only. Recovery ranges from 65 percent to 80 percent, depending on the type of mining used to extract ore and on the specific metallurgical factors that are used to produce uranium from this ore.

The "2009 Red Book" reported 3.5 million tU of economic recoverable RAR worldwide (extractable for less than USD 130/kgU) (fig. 13, table 5) (NEA-IAEA, 2010). It was expected that the RAR in the development pipeline as estimated from this analysis would represent a subset of NEA's total reported economic reserve. The reserve base that is currently coming online represents 60 percent of RAR reported in the NEA-IAEA cost categories "less than USD 130/kgU" (fig. 13), which are economic at current uranium prices.

At 2010 rates of demand $(68,646 \mathrm{tU}$; World Nuclear Association, 2011b), uranium in operating mines, or those that will be coming online in the near future as calculated in this report, would fuel the world nuclear power reactor fleet for about 30 years, depending on the percentage of actual uranium recovery during mining. However, this rate does not take into account future demand from the 61 reactors under construction, from 158 reactors planned or on order, or from 326 proposed reactors (World Nuclear Association, 2011b).

\section{Reserve Distribution by Projected Mining Method}

Conventional operating mines contain 68 percent of in-situ RAR, and 63 percent of the identified nominal capacity for uranium production, whereas ISL mines contain 32 percent of RAR and contribute 37 percent of reported capacity (table 6). ISL mines currently operate in Kazakhstan, the United States, Australia, China, Uzbekistan, and Russia (with one ISL mine planned for Pakistan). The share of future ISL capacity measured from advanced-stage properties (those expected to produce within the five years 2011-2015) is expected to fall to 20 percent of the total uranium being produced, and resources attributable to ISL in upcoming mines is a much lower 16 percent. Conventional mines expected to come online in the next 5 to 10 years (2011-2021) are estimated to contribute 84 percent of the resources, and to provide 80 percent of the capacity to future production. However, many properties in development do not report proposed capacity. Therefore future production estimates should be considered as minimums, and the ratios of future ISL to conventional mined uranium should be considered as supply estimates only. Note that the category of "developing conventional mines" includes proposed mines for which a production method is undetermined, byproduct production, and mining of dumps, in addition to open pit and underground operations.

\section{Top 10 Producers}

The top 10 producing mines in 2009 contributed about $30,600 \mathrm{tU}$, or 62 percent of world production (table 1). Fortyfour percent of the world's uranium resources in operating mines is contained in these ten mines. However, production is not expected to continue at current capacity from many of the top ten. Production from Ranger, the second largest producer in 2009, is likely to decline as the mine depletes known high-grade resources and moves to develop lower-grade ores on leach piles not originally processed, and deeper targets. Olympic Dam, the sixth largest producer, will continue to produce only if prices for copper and gold, the primary commodities, remain high, and if capital can be raised for a significant expansion. Ore at Rabbit Lake/Eagle Point, the eighth largest producer, is nearly exhausted. 


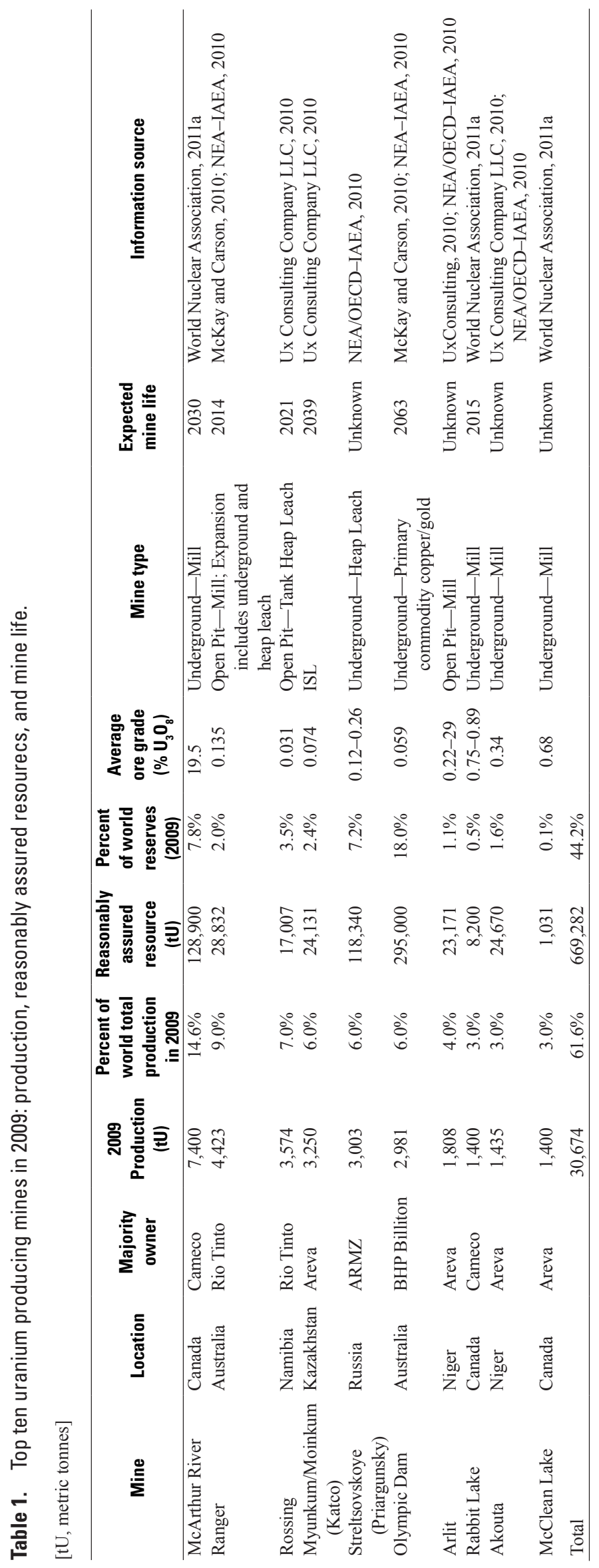




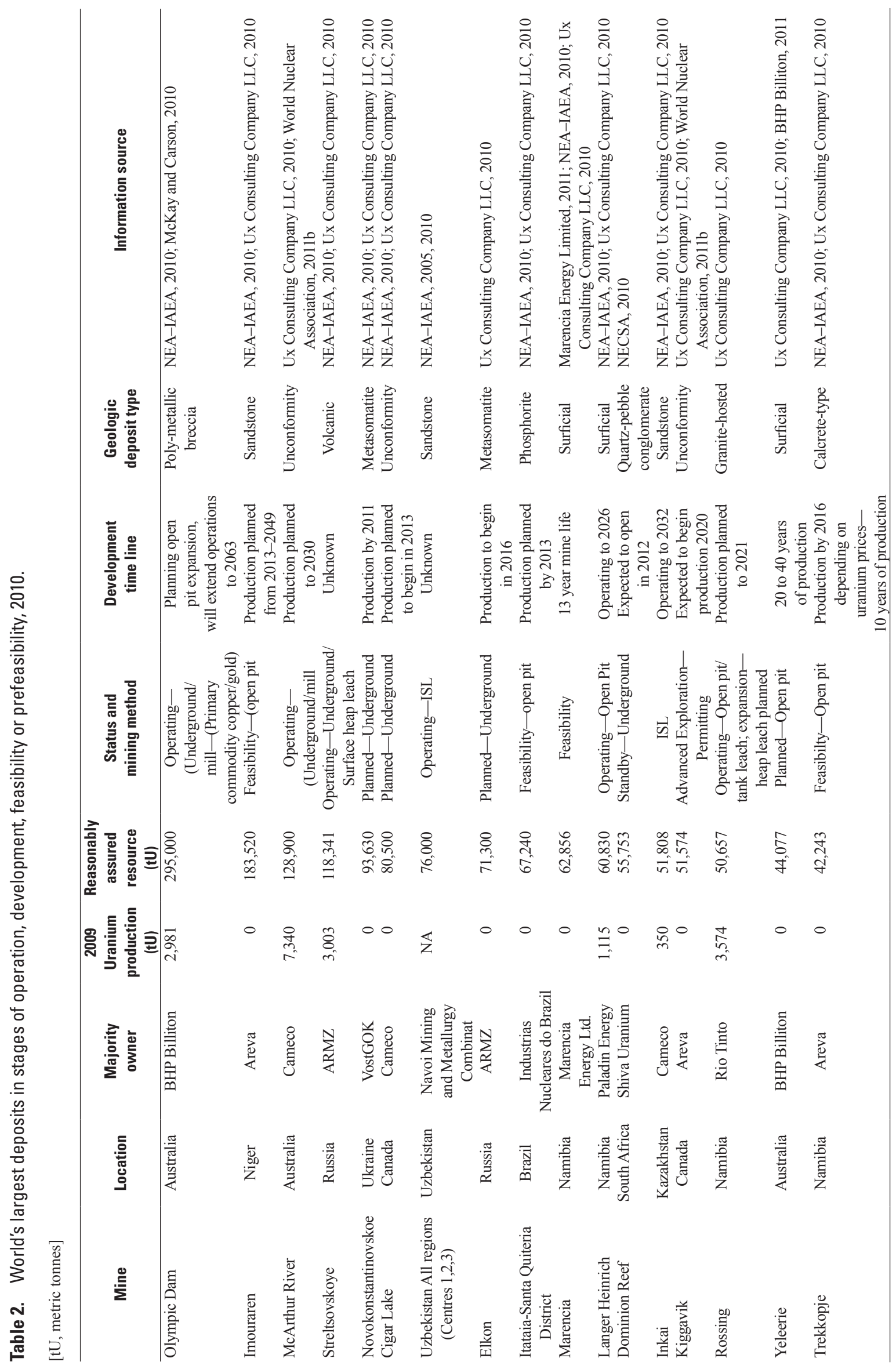


Table 3. Operating uranium mines and their remaining reasonably assured resources, 2010.

[tU, metric tonnes; $\mathrm{tU} / \mathrm{yr}$, metric tonnes per year; ISL, in-situ leach. In-situ resources reported, when 2009 Redbook cited information was for production or other descriptive information or where there was no other source of resource data]

\begin{tabular}{|c|c|c|c|c|c|}
\hline $\begin{array}{c}\text { Mine/ } \\
\text { production center }\end{array}$ & Country & $\begin{array}{c}\text { Remaining } \\
\text { in-situ reserve tU } \\
\text { (proven and } \\
\text { probable economic) }\end{array}$ & $\begin{array}{l}\text { Grade } \\
\% U\end{array}$ & Ownership & $\begin{array}{l}\text { End of } \\
\text { mine life }\end{array}$ \\
\hline Olympic Dam & Australia & 295,000 & 0.059 & BHP Billiton & 2063 \\
\hline Ranger & Australia & 28,832 & 0.117 & Rio Tinto & 2020 \\
\hline McArthur River & Canada & 128,900 & $15.72-26.33$ & Cameco Corporation & $>2031$ \\
\hline McClean Lake & Canada & 1,031 & 0.530 & Areva Resources Canada Inc. & NA \\
\hline Rabbit Lake/Eagle Point & Canada & 8,200 & 0.880 & Cameco Corporation & 2015 \\
\hline Lianshanguan & China & 1,000 & 0.340 & China National Nuclear Corporation & NA \\
\hline Qinglong district & China & 8,000 & NA & China National Nuclear Corporation & NA \\
\hline Shaoguan & China & NA & NA & China National Nuclear Corporation & NA \\
\hline Tengchong deposit & China & 6,000 & 0.050 & China National Nuclear Corporation & NA \\
\hline Xiangshan district & China & 29,000 & 0.100 & China National Nuclear Corporation & NA \\
\hline Xiazhuang district & China & 12,000 & NA & China National Nuclear Corporation & NA \\
\hline Bagjata & India & 2,106 & 0.047 & Uranium Corporation of India & NA \\
\hline Bhatin & India & 2,200 & 0.050 & Uranium Corporation of India & NA \\
\hline Jaduguda & India & 8,400 & 0.067 & Uranium Corporation of India & NA \\
\hline Narwapahar & India & 11,500 & 0.050 & Uranium Corporation of India & NA \\
\hline Turamdih/Banduhurang & India & 3,750 & 0.046 & Uranium Corporation of India & NA \\
\hline Gachin (Bandar-Abas) & Iran & 100 & 0.200 & Atomic Energy Organization of Iran & NA \\
\hline Akdala & Kazakhstan & 9,308 & 0.070 & Uranium One Inc., KazAtomProm & NA \\
\hline $\begin{array}{l}\text { Budenovskoye 1-3-4/ } \\
\text { Akbastau }\end{array}$ & Kazakhstan & 10,737 & 0.090 & Uranium One Inc., KazAtomProm & NA \\
\hline Budenovskoye 2/Karatau & Kazakhstan & 11,232 & 0.090 & KazAtomProm, Uranium One Inc. & NA \\
\hline $\begin{array}{l}\text { Centralnoye (Kanzhagan, } \\
\text { S. Muyumkum) }\end{array}$ & Kazakhstan & 25,077 & 0.070 & KazAtomProm & NA \\
\hline $\begin{array}{l}\text { Chiili (North and } \\
\text { South Karamurun) }\end{array}$ & Kazakhstan & 27,403 & 0.070 & KazAtomProm & NA \\
\hline Inkai & Kazakhstan & 51,808 & 0.070 & $\begin{array}{c}\text { Cameco Corporation, } \\
\text { KazAtomProm }\end{array}$ & 2032 \\
\hline Inkai South & Kazakhstan & 13,040 & 0.039 & Uranium One Inc., KazAtomProm & NA \\
\hline Irkol & Kazakhstan & 28,641 & 0.045 & KazAtomProm, China Guangdong NPC & NA \\
\hline Mynkuduk Central & Kazakhstan & 48,521 & 0.040 & KazAtomProm & NA \\
\hline
\end{tabular}


Table 3. Operating uranium mines and their remaining reasonably assured resources, 2010.-Continued

[tU, metric tonnes; $\mathrm{tU} / \mathrm{yr}$, metric tonnes per year; ISL, in-situ leach. In-situ resources reported, when 2009 Redbook cited information was for production or other descriptive information or where there was no other source of resource data]

\begin{tabular}{|c|c|c|c|c|}
\hline $\begin{array}{c}\text { Mine/ } \\
\text { production center }\end{array}$ & $\begin{array}{c}\text { Production or } \\
\text { nominal production } \\
\text { capacity/rate } \\
\text { (tU/yr) }\end{array}$ & $\begin{array}{l}\text { Geologic } \\
\text { type }\end{array}$ & $\begin{array}{c}\text { Type of } \\
\text { operation }\end{array}$ & Information source \\
\hline Olympic Dam & 3,820 & $\begin{array}{l}\text { Hematite } \\
\text { Breccia Complex }\end{array}$ & $\begin{array}{l}\text { Underground- } \\
\qquad \mathrm{Cu} / \mathrm{Au}\end{array}$ & McKay and Carson, 2010; NEA-IAEA, 2010 \\
\hline Ranger & 4,660 & $\begin{array}{l}\text { Unconformity- } \\
\text { Proterozoic }\end{array}$ & Open Pit & McKay and Carson, 2010; NEA-IAEA, 2010 \\
\hline Lagoa Real-Caetite District & 340 & Metasomatite & Open Pit & NEA-IAEA, 2010; Ux Consulting Company LLC, 2010 \\
\hline McArthur River & 7,200 & $\begin{array}{l}\text { Unconformity- } \\
\text { Proterozoic }\end{array}$ & Underground & $\begin{array}{l}\text { World Nuclear Association, 2011b; Ux Consulting } \\
\text { Company LLC, } 2010\end{array}$ \\
\hline McClean Lake & 3,077 & $\begin{array}{l}\text { Unconformity- } \\
\text { Proterozoic }\end{array}$ & Underground & $\begin{array}{l}\text { World Nuclear Association, 2011b; Ux Consulting } \\
\text { Company LLC, } 2010\end{array}$ \\
\hline Rabbit Lake/Eagle Point & 4,615 & $\begin{array}{l}\text { Unconformity- } \\
\text { Proterozoic }\end{array}$ & Underground & $\begin{array}{l}\text { World Nuclear Association, } 2011 \text { b; Ux Consulting } \\
\text { Company LLC, } 2010\end{array}$ \\
\hline Lianshanguan & 220 & $\begin{array}{c}\text { Granite (Benxi) } \\
\text { Granite (Qinglong) }\end{array}$ & Unknown & Dahlkamp, 2010 \\
\hline Qinglong district & 100 & NA & NA & NEA-IAEA, 2010 \\
\hline Shaoguan & 100 & Granite & Underground & NEA-IAEA, 2010 \\
\hline Tengchong deposit & NA & Sandstone & ISL & NEA-IAEA, 2010 \\
\hline Xiangshan district & 200 & Volcanic & $\begin{array}{l}\text { Underground/ } \\
\text { Mill }\end{array}$ & NEA-IAEA, 2010; Ux Consulting Company LLC, 2010 \\
\hline Xiazhuang district & NA & Granite or Vein & NA & Ux Consulting Company LLC, 2010 \\
\hline Bagjata & Part of Jaduguda & Vein & Underground & Chaki, 2010 \\
\hline Bhatin & Part of Jaduguda & Vein & Underground & NEA-IAEA 2010; Ux Consulting Company LLC, 2010 \\
\hline Jaduguda & 175 & Vein & Underground & NEA-IAEA, 2010; Ux Consulting Company LLC, 2010 \\
\hline Narwapahar & Part of Jaduguda & Vein & Underground & NEA-IAEA, 2010; Ux Consulting Company LLC, 2010 \\
\hline Turamdih/Banduhurang & 190 & Vein & Underground & NEA-IAEA, 2010; Ux Consulting Company LLC, 2010 \\
\hline Gachin (Bandar-Abas) & 21 & Surficial & Open Pit & NEA-IAEA, 2010 \\
\hline Akdala & 1,000 & Sandstone & ISL-Acid Leach & NEA-IAEA, 2010; Ux Consulting Company LLC, 2010 \\
\hline $\begin{array}{l}\text { Budenovskoye 1-3-4/ } \\
\text { Akbastau }\end{array}$ & 3,000 & Sandstone & ISL-Acid Leach & NEA-IAEA, 2010; Ux Consulting Company LLC, 2010 \\
\hline Budenovskoye 2/Karatau & 1,000 & Sandstone & ISL-Acid Leach & NEA-IAEA, 2010; Ux Consulting Company LLC, 2010 \\
\hline $\begin{array}{l}\text { Centralnoye (Kanzhagan, } \\
\text { S. Muyumkum) }\end{array}$ & 1,000 & Sandstone & ISL_-Acid Leach & NEA-IAEA, 2010; Ux Consulting Company LLC, 2010 \\
\hline $\begin{array}{l}\text { Chiili (North and } \\
\text { South Karamurun) }\end{array}$ & 1,000 & Sandstone & ISL—Acid Leach & NEA-IAEA, 2010; Ux Consulting Company LLC, 2010 \\
\hline Inkai & 2,000 & Sandstone & ISL_-Acid Leach & NEA-IAEA, 2010; Ux Consulting Company LLC, 2010 \\
\hline Inkai South & 2,000 & Sandstone & ISL_-Acid Leach & NEA-IAEA, 2010; Ux Consulting Company LLC, 2010 \\
\hline Irkol & 750 & Sandstone & ISL_-Acid Leach & NEA-IAEA, 2010; Ux Consulting Company LLC, 2010 \\
\hline Mynkuduk Central & 2,000 & Sandstone & ISL-Acid Leach & NEA-IAEA, 2010; Ux Consulting Company LLC, 2010 \\
\hline
\end{tabular}


Table 3. Operating uranium mines and their remaining reasonably assured resources, 2010._Continued

[tU, metric tonnes; $\mathrm{tU} / \mathrm{yr}$, metric tonnes per year; ISL, in-situ leach. In-situ resources reported, when 2009 Redbook cited information was for production or other descriptive information or where there was no other source of resource data]

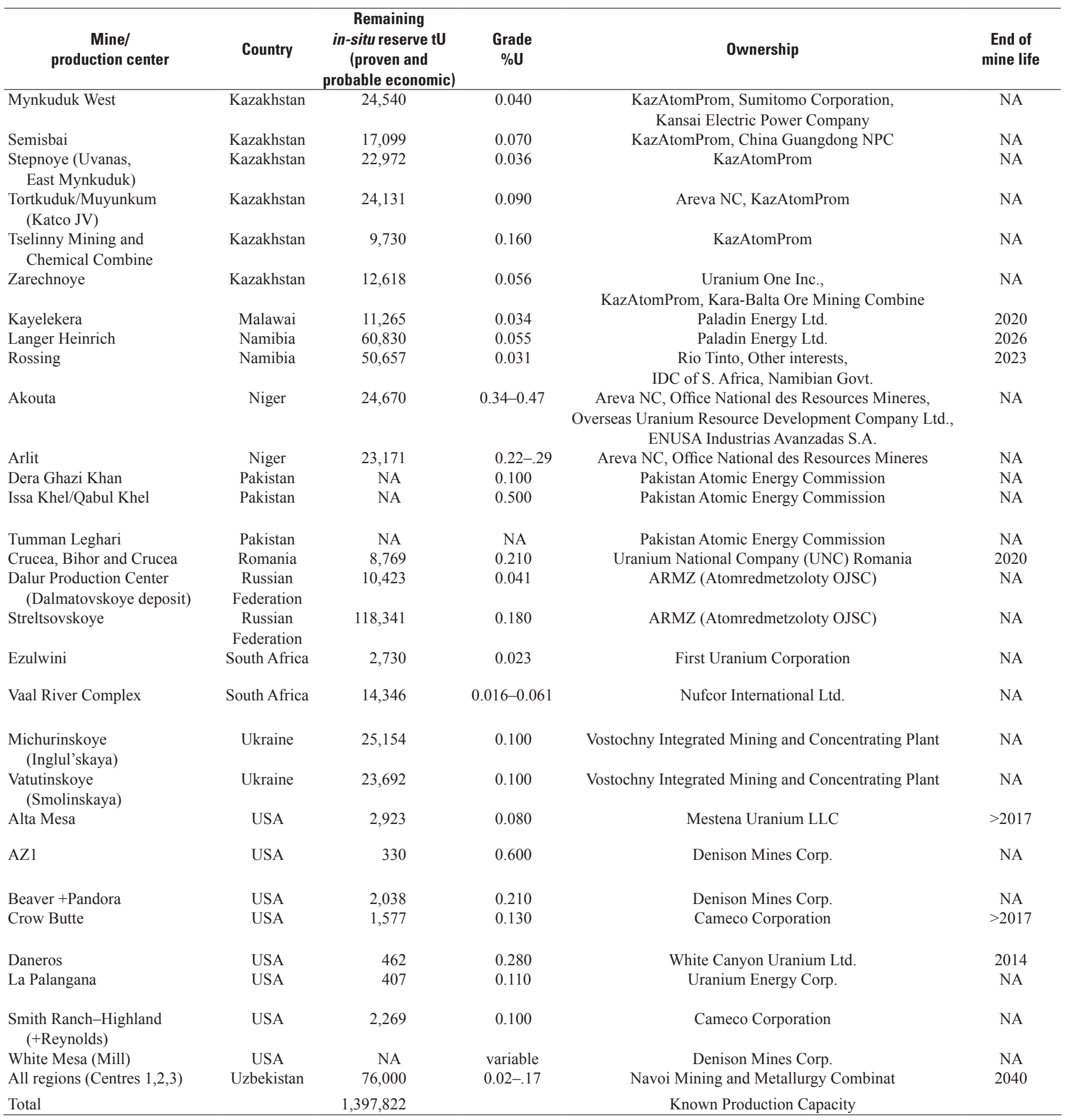


Table 3. Operating uranium mines and their remaining reasonably assured resources, 2010.-Continued

[tU, metric tonnes; $\mathrm{tU} / \mathrm{yr}$, metric tonnes per year; ISL, in-situ leach. In-situ resources reported, when 2009 Redbook cited information was for production or other descriptive information or where there was no other source of resource data]

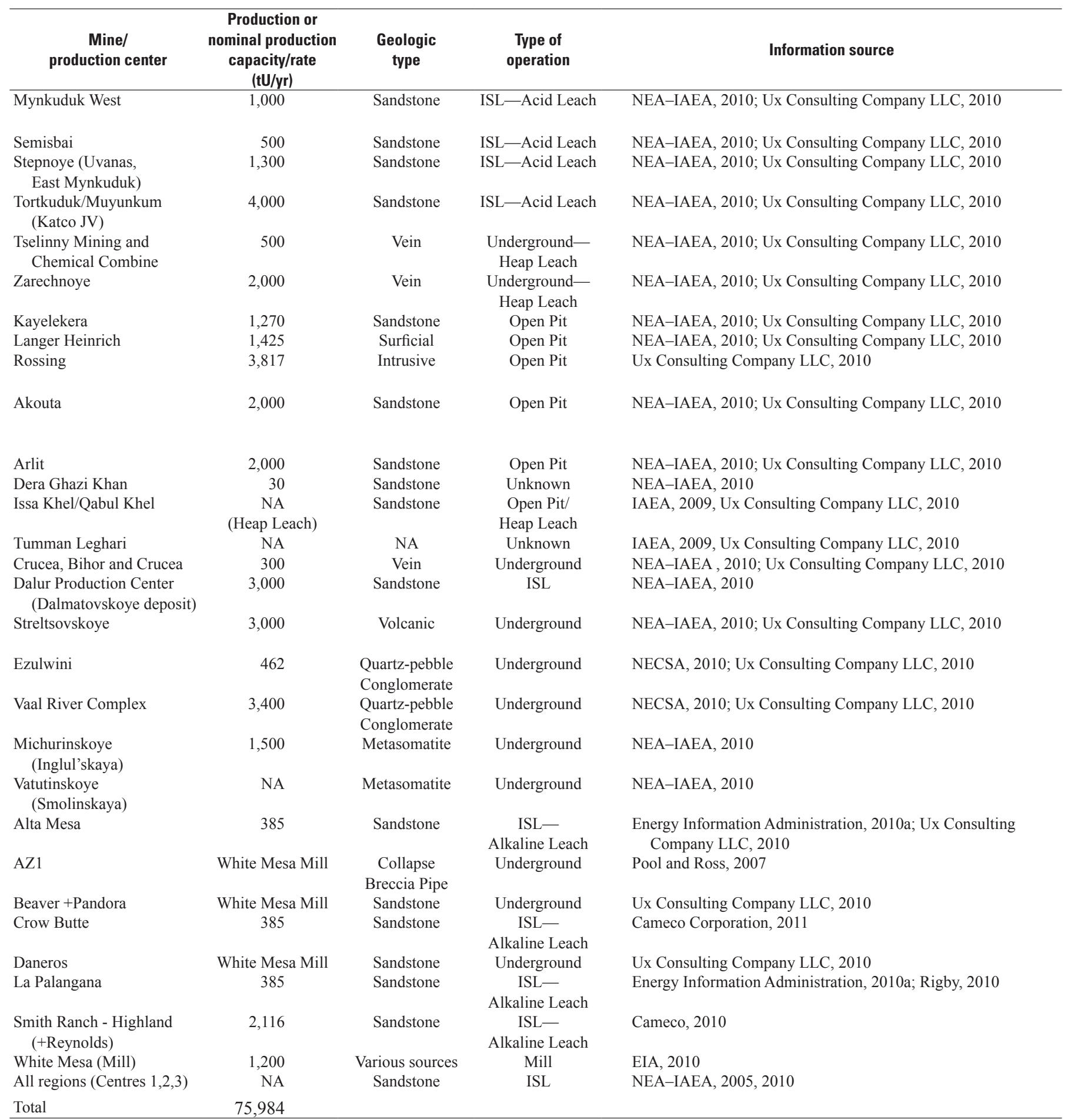

*No available information, used estimates from NEA-IAEA (2010) which probably do not account for depletion by mining.

"Updated grades not available, used information from IAEA, 2010. 
Table 4. Uranium properties that are permitted, or in feasibility or in the prefeasibility stages and their reported resources, 2010.

[UG, underground; ISL, in-situ leach; OP, open pit; R, resource only, not reserve; I, indicated resource; NA, data not available; tU/yr, metric tonnes per year. Values used because the unique character of the deposits and proposed mining method will likely not yield a reserve prior to development. In-situ resources reported, when 2009 Redbook cited information was for production or other descriptive information or where there was no other source of resource data]

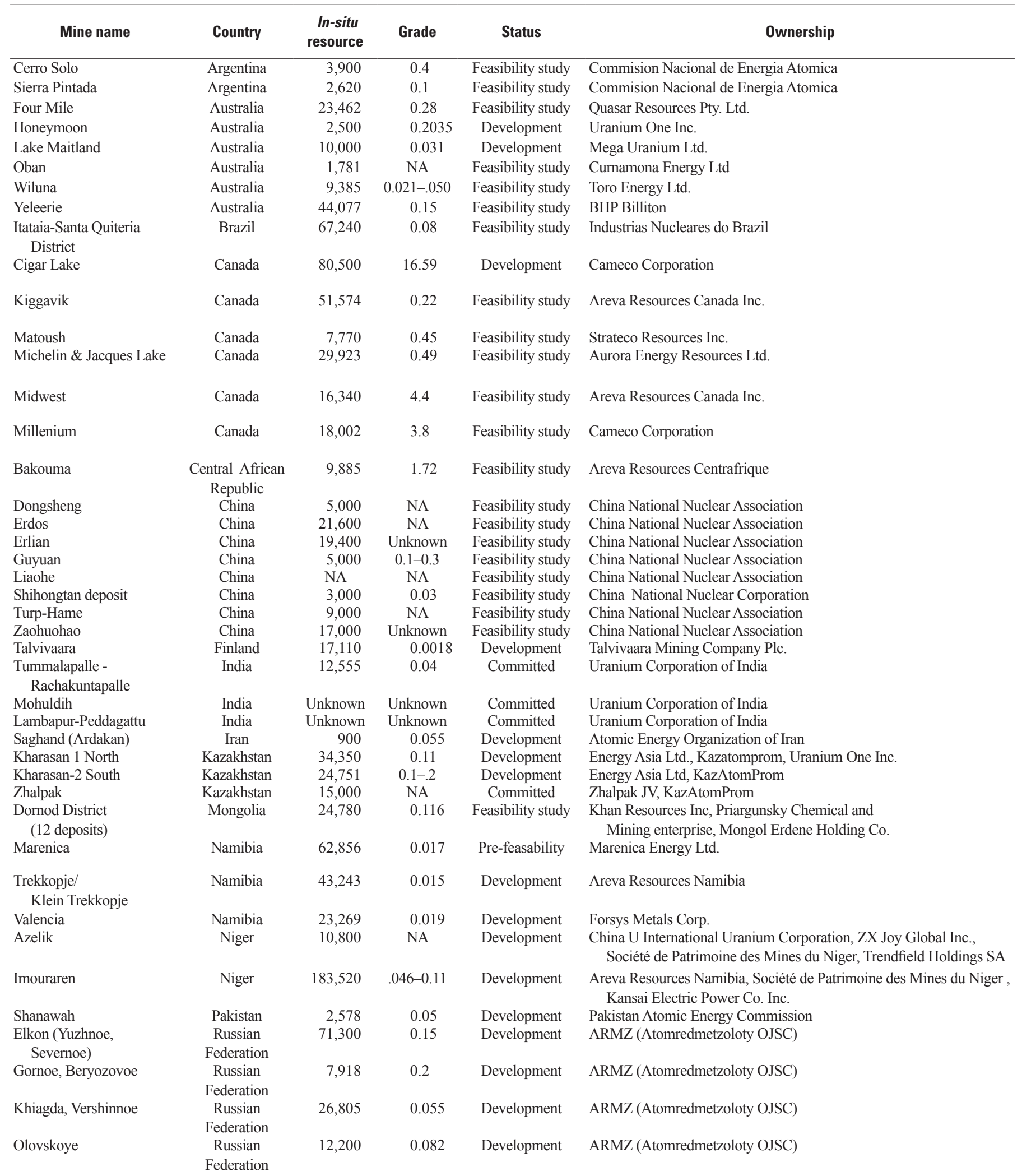


Table 4. Uranium properties that are permitted, or in feasibility or in the prefeasibility stages and their reported resources, 2010. - Continued

[UG, underground; ISL, in-situ leach; OP, open pit; R, resource only, not reserve; I, indicated resource; NA, data not available; tU/yr, metric tonnes per year. Values used because the unique character of the deposits and proposed mining method will likely not yield a reserve prior to development. In-situ resources reported, when 2009 Redbook cited information was for production or other descriptive information or where there was no other source of resource data]

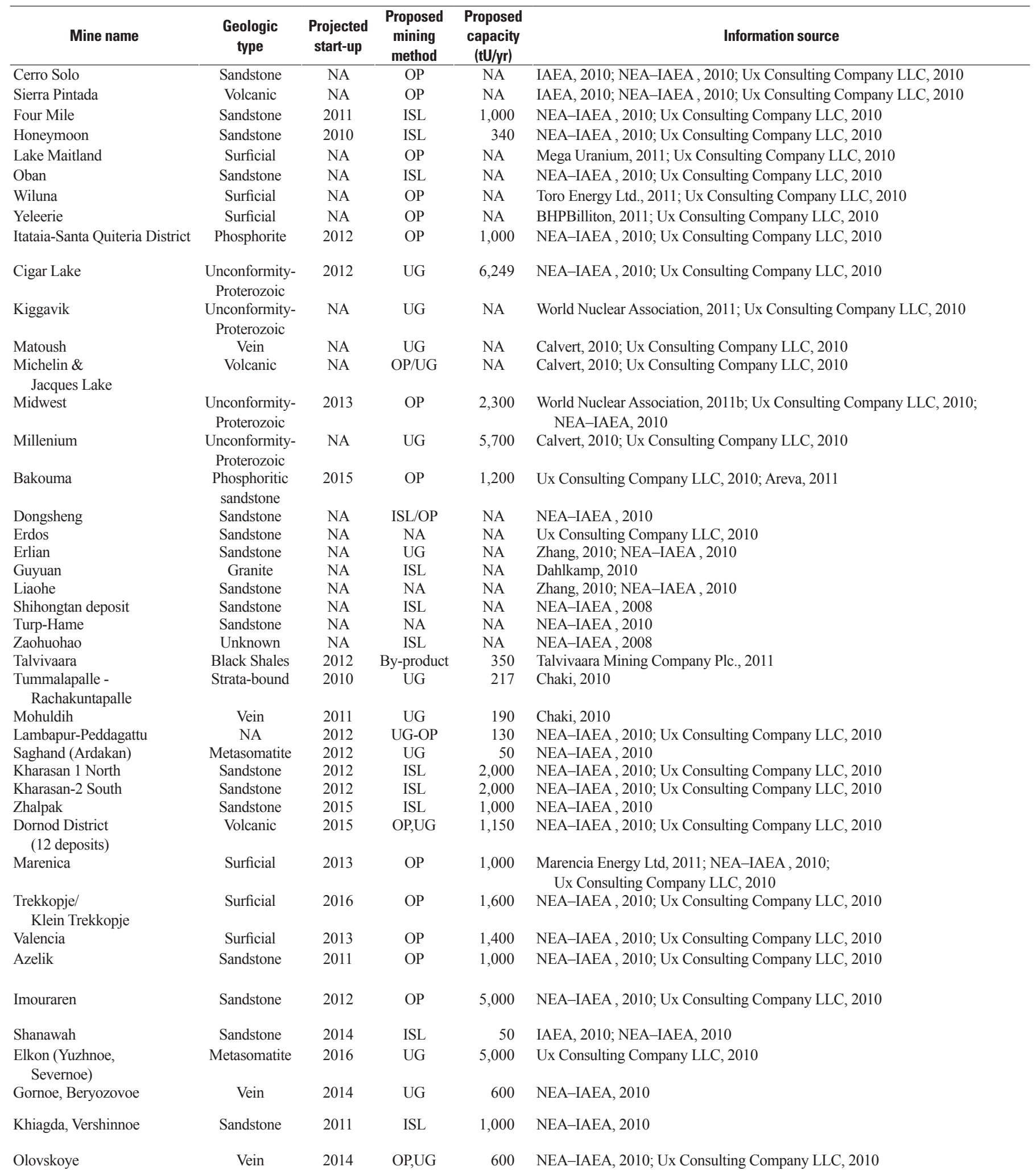


Table 4. Uranium properties that are permitted, or in feasibility or in the prefeasibility stages and their reported resources, 2010. -Continued

[UG, underground; ISL, in-situ leach; OP, open pit; R, resource only, not reserve; I, indicated resource; NA, data not available; tU/yr, metric tonnes per year. Values used because the unique character of the deposits and proposed mining method will likely not yield a reserve prior to development. In-situ resources reported, when 2009 Redbook cited information was for production or other descriptive information or where there was no other source of resource data]

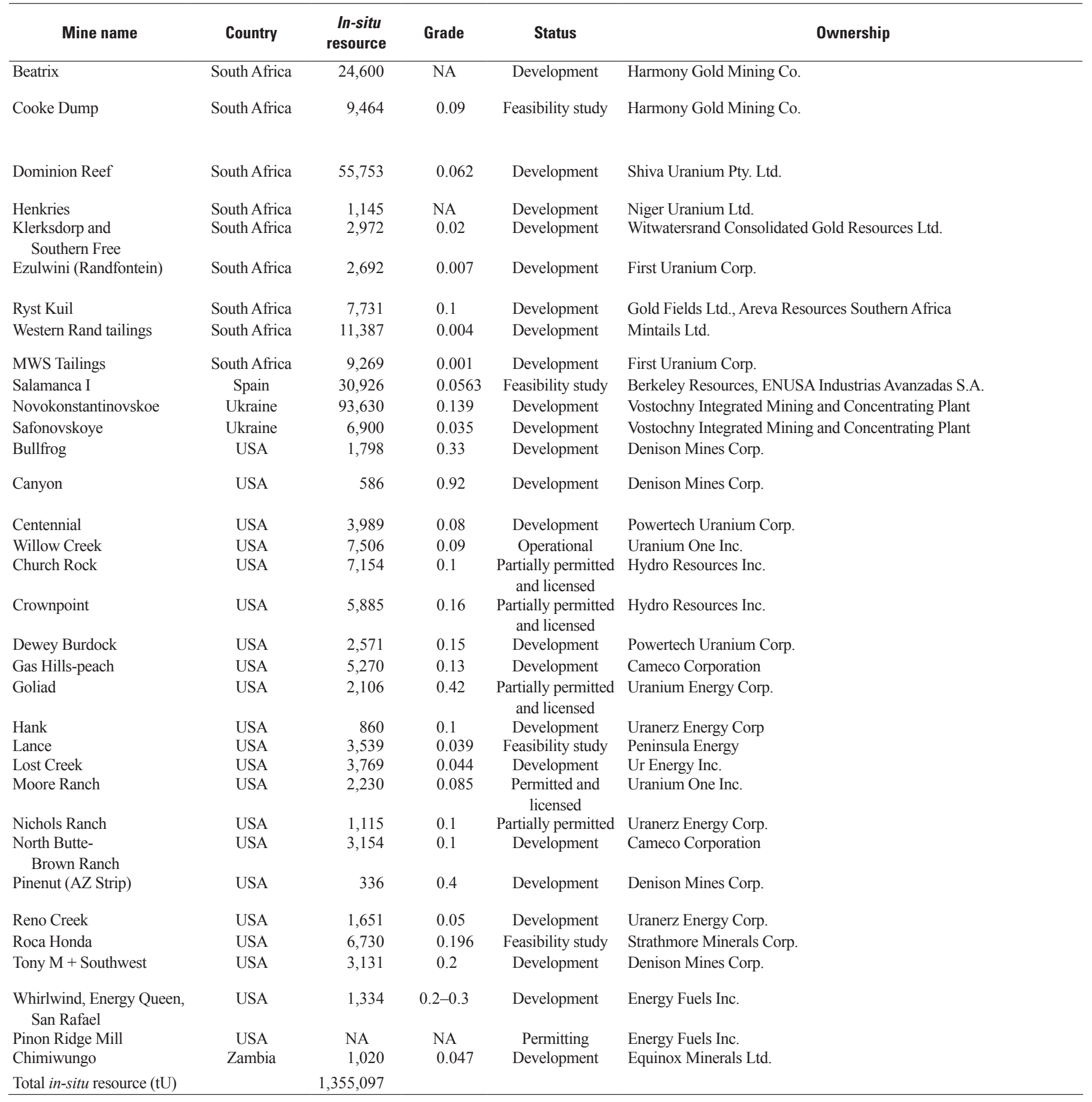


Table 4. Uranium properties that are permitted, or in feasibility or in the prefeasibility stages and their reported resources, 2010. - Continued

[UG, underground; ISL, in-situ leach; OP, open pit; R, resource only, not reserve; I, indicated resource; NA, data not available; tU/yr, metric tonnes per year. Values used because the unique character of the deposits and proposed mining method will likely not yield a reserve prior to development. In-situ resources reported, when 2009 Redbook cited information was for production or other descriptive information or where there was no other source of resource data]

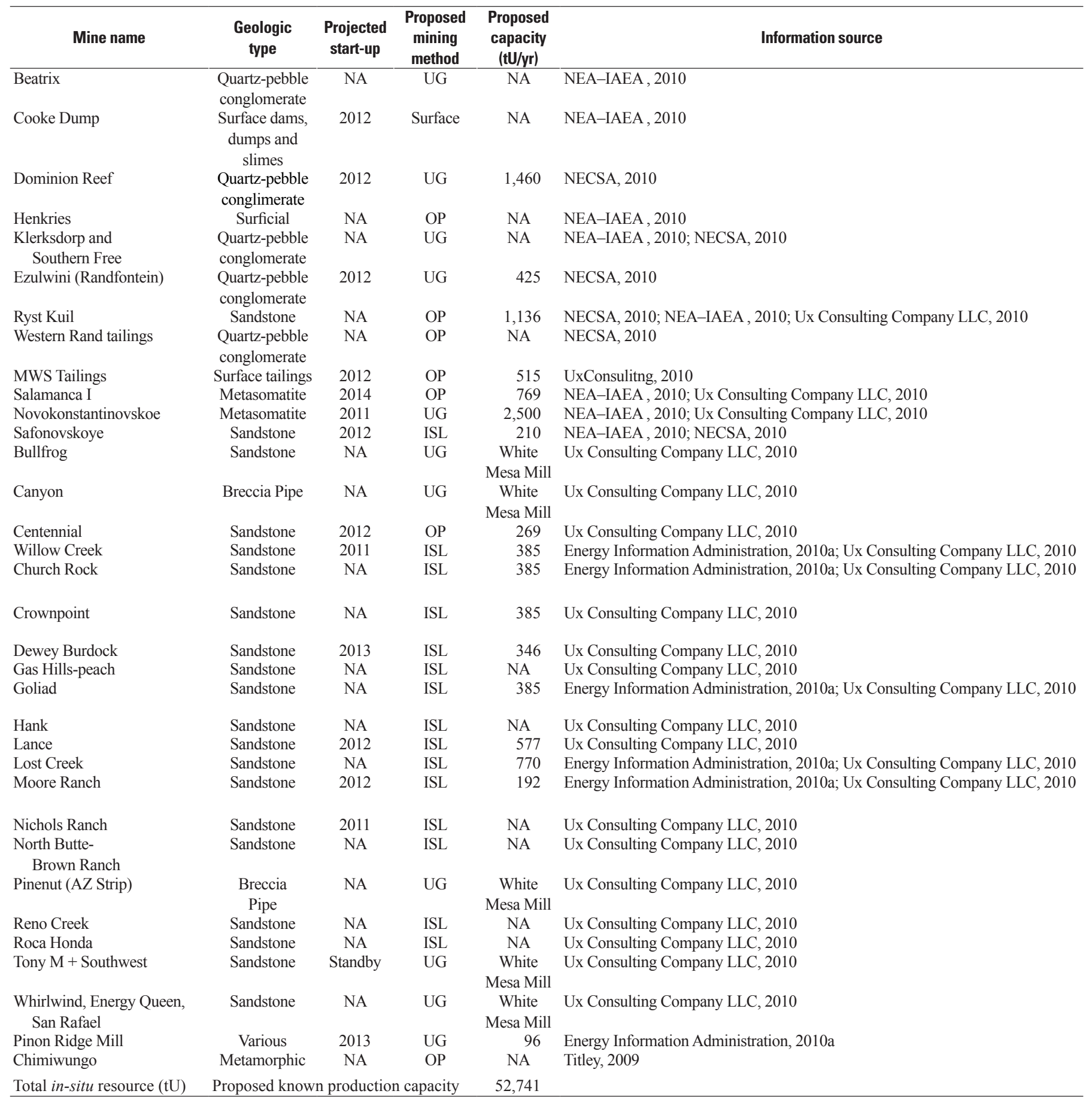

${ }^{1}$ Uses measured and indicated resource (demonstrated economic) estimates when those are available. No cost cutoffs or ranges are included since mines are in planning stages. Estimates for some mines may include inferred resources.

*No available information, used IAEA, 2010 estimates which probably do not account for depletion by mining.

\#Updated grades not available, used original IAEA, 2010 values. 
Geologic Assurance for and Economic Feasibility of Worldwide Uranium Resources, 2010

Decreasing degree of geological assurance

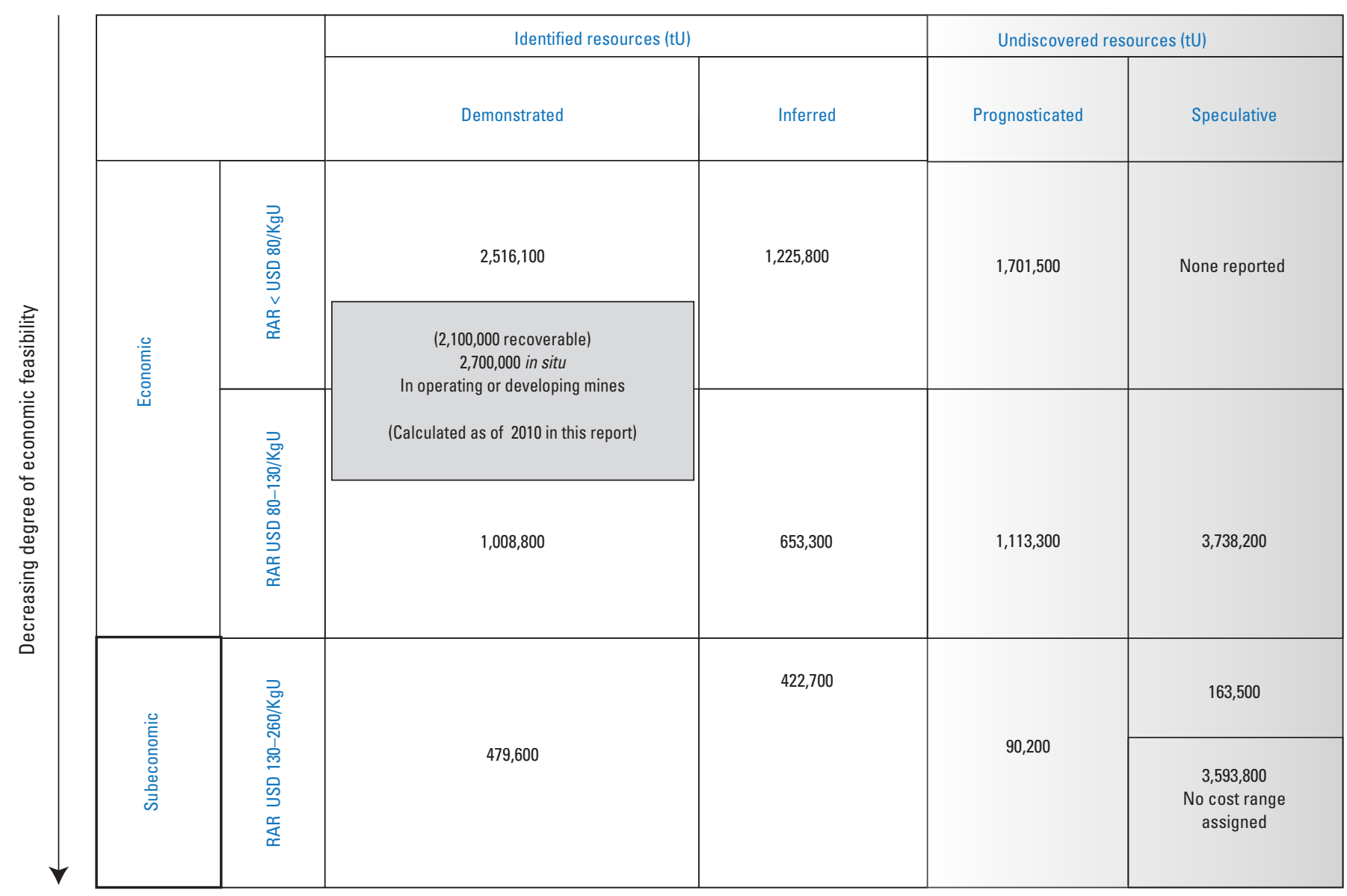

\begin{tabular}{|c|c|c|}
\hline \multirow{4}{*}{$\begin{array}{c}\text { Unconventional } \\
\text { resources }\end{array}$} & \multicolumn{2}{|c|}{ Uraniferous Phosphate: Demonstrated and Inferred Resource 7.3-7.6 million tU (NEA-IAEA, 2010) } \\
\hline & Black Shale Deposits: & 1,061,958 tU—IAEA UDEPO database (IAEA, 2010) \\
\hline & Lignite Deposits: & 224,360 tU—IAEA UDEPO database (IAEA, 2010) \\
\hline & Seawater: & Approximately 4,000,000,000 tU (NEA-IAEA, 2010) (uneconomic) \\
\hline
\end{tabular}

Secondary Sources:

Enrichment tails

Stockpiles

$1,600,000$ tU

worldwide (production depends on enrichment capacity)

LEU

(from the HEU-LEU program, expires in 2013; USEC, 2011)

Note: RAR tU is reported as recoverable uranium (milling and mining losses deducted) except for unconventional and secondary sources that are too speculative to treat as RAR. Data from the 2009 Red Book (NEA-IAEA, 2010) except where indicated.

Figure 13. Uranium Resources Mapped to Resource Category Geological assurance for, and economic feasibility of, worldwide uranium resources, by resource categories used by the Organisation for Economic Co-operation Nuclear Agency and International Atomic Energy Agency. 
Table 5. Reasonably assured resources reported in the 2009 Red Book (NEA-IAEA, 2010).

[tU, metric tonnes; kg, kilograms; USD, U.S. dollars]

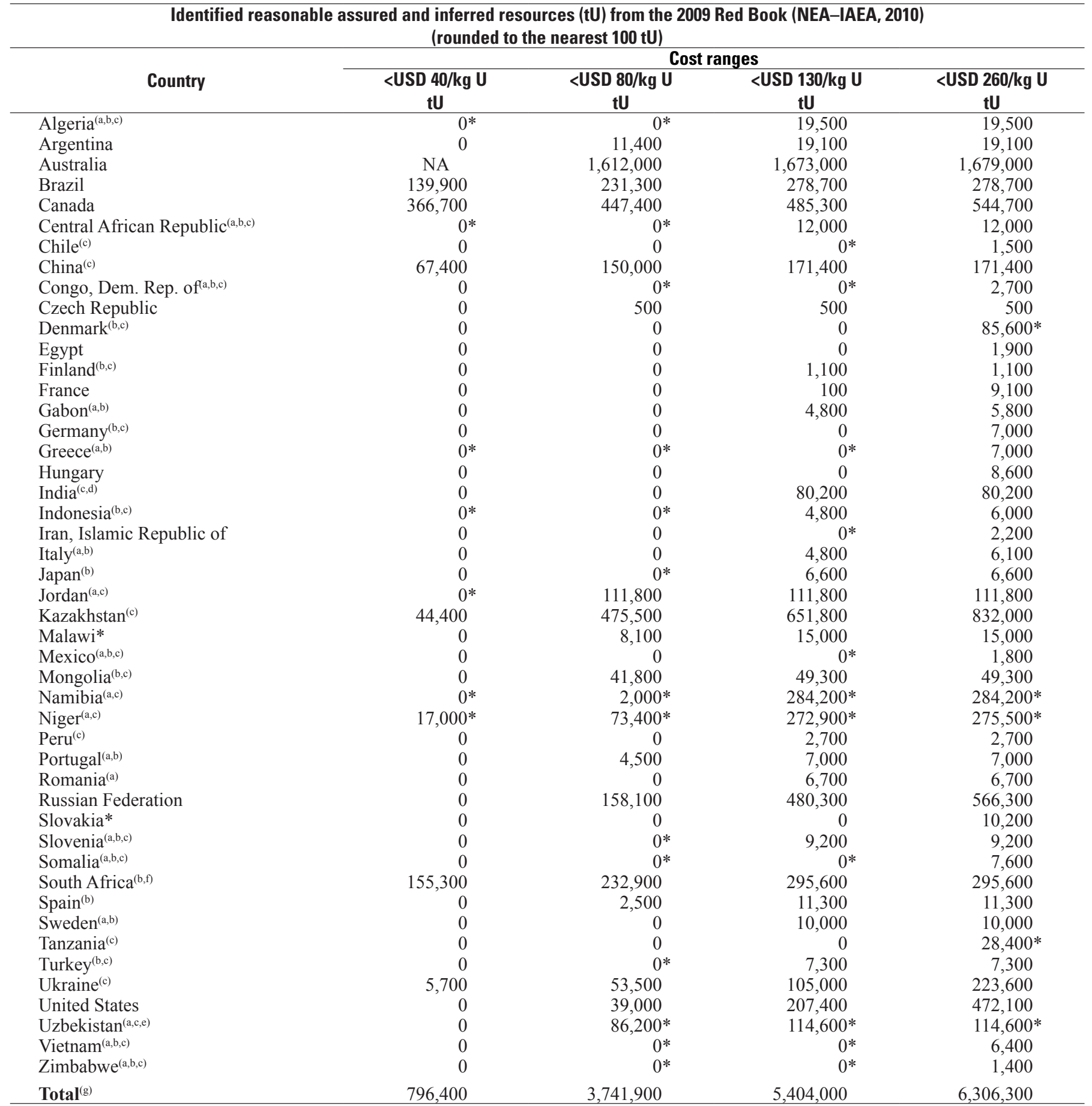

*IAEA Uranium Group Secretariat estimate.

(a) Not reported in 2009 responses, data from previous Red Book.

${ }^{(b)}$ Assessment not made within the last five years.

(c)In-situ resources were adjusted by the Secretariat to estimate recoverable resources using recovery factors provided by countries or estimated by the Secretariat according to the expected production method.

${ }^{(d)}$ Cost data are not provided, therefore resources are reported in the $<$ USD $130 / \mathrm{kgU}$ category.

${ }^{(e)}$ Data from 2007 Red Book (NEA-OECD, 2008), reduced by past production.

${ }^{(\mathrm{f})}$ Resource estimates do not account for production.

${ }^{(g)}$ Totals related to cost ranges $<$ USD $40 / \mathrm{kgU}$ and $<$ USD $80 / \mathrm{kgU}$ are higher than reported in the tables because certain countries do not report resource estimates, mainly for reasons of confidentiality. 
Table 6. Reasonably assured resources (RAR) and production capacity of operating and proposed mines by extraction technology.

[tU, metric tonnes; tU/yr, metric tonnes per year; ISL, in-situ leaching]

\begin{tabular}{lcc}
\hline & $\begin{array}{c}\text { Reasonably assured } \\
\text { in-situ resources } \\
\text { (tU) }\end{array}$ & $\begin{array}{c}\text { Nominal } \\
\text { production capacity } \\
\text { (tU/yr) }\end{array}$ \\
\hline \multicolumn{3}{c}{ Operating mines } \\
\hline ISL mines & 443,600 & 28,000 \\
Conventional mines & 954,200 & 48,000 \\
\hline ISL mines & Developing mines \\
Conventional mines & 221,700 & 11,000 \\
\hline
\end{tabular}

Resources and capacity rounded to the nearest 100 tU. Production capacity for developing mines is estimated.

\section{Largest Advanced-stage Projects and Operating Mines}

A number of mines are expected to continue to produce uranium, and several new mines with significant resources are projected to come online within the 5 years 2012-2016 (tables 3, 4). Production rates for future mines are uncertain, and the mines with the largest resources may not have the highest production rate. Expansion of the Olympic Dam mining operation in Australia, pending financing, would potentially be the largest resource and producer, increasing current production sixfold (Mckay and Carson, 2010). In August 2012 BHP Billiton announced they would be delaying the expansion of Olympic Dam indefinitely (ABC News, 2012). The world's second largest resource after Olympic Dam, the Imouraren mine in Niger, is expected to begin producing uranium in 2014, and to continue for 35 years, through 2045. Canada's McArthur River mine, with the world's third largest reserve, has plans to continue production until 2030. The fourth largest deposit, Priargunsky/ Streltsovskoye in Russia, is expected to continue as a producer. The Novokonstantinovskoe mine in Ukraine opened in 2011, bringing a large resource to the world market through a significant investment of $\$ 500$ million from Russia. Although a series of mine floods have delayed development of Cigar Lake mine, also in Canada, production is expected to begin in 2013. Uzbekistan's ISL properties are expected to continue to produce. Uzbekistan's official program has a goal of increasing State production by 50 percent by 2012, but this increase is dependent on financing of State-owned mines. The Russian Elkon deposit is reported to be targeting uranium production by 2016 . Brazil is working to bring Itatiaia-Santa Quitéria, a large unconventional uraniferous phosphate resource, to production by 2013. Namibia will continue as a major producer, with continued mining at the Rossing and the Langer Heinrich deposits. The Dominion Reef mine in South Africa is scheduled to begin to produce in the near future following a change in ownership from Uranium One to Shiva Uranium Pty. Ltd. Kazakhstan's two largest resource projects, Katco and Inkai, are expected to continue to produce; it is anticipated Inkai will be mined until at least 2032. The Areva NC (Areva) Kiggavik mine in Canada is projected to produce by 2017 or 2018, although the production timeline is uncertain because this project is in the feasibility stage. BHP Billiton appeared to be moving forward in developing the surficial Yeelirrie mine after a mining ban in Western Australia was lifted in 2008, making exploitation possible. However, in 2010 BHP Billiton announced that it would be putting the environmental permitting process on hold, delaying production, and sold the property to Cameco in 2012. Areva's Trekkopje deposit in Niger is currently suspended pending increased uranium prices after the resource estimate was reduced because chemical assays did not confirm the uranium content projected by radiometric surveys (Areva NC, 2011).

\section{Undiscovered Resources}

Undiscovered resources both prognosticated and speculative, are those that, on the basis of earlier discoveries in similar geologic settings, are expected to be found. "Prognosticated resources" have some direct evidence for their occurrence, and "speculative resources" are expected to occur, but with no direct evidence that they exist. Thirty three countries have historically reported some undiscovered resources to NEA (table 7). Potentially economic prognosticated resources (extractable for $<$ USD $130 / \mathrm{kgU}$ ) total 2.8 million tU, and economic speculative resources total 3.7 million tU (NEA-IAEA, 2010). Subeconomic undiscovered resources (prognosticated and speculative), including those ( 3.5 million $\mathrm{tU}$ ) for which no cost range has been assigned, total 7.5 million tU.

The global distribution of reported undiscovered resources in many cases reflects the intensity and scope of past and (or) current government or industry mineral exploration programs. The United States reports the largest prognosticated resource (1.2 million tU), followed by Kazakhstan $(500,000 \mathrm{tU})$ and Brazil (300,000 tU) (fig. 14). Mongolia and the United States both report 1.3 million $\mathrm{tU}$ in the speculative resource category, South Africa 1.1 million tU, Canada 700,000 tU and Brazil 500,000 tU (fig. 15). Other countries report smaller undiscovered resources. The U.S. National Uranium Resource Evaluation (NURE) program, one of the most active programs for evaluating undiscovered resources, may in part account for its large number of undiscovered resources; the program ended in 1982. Conversely, resourcerich Australia and Namibia do not calculate undiscovered resources at a national scale, and so their potential resources are unreported. 
Table 7. Undiscovered resources, in thousands of tonnes uranium metal, as reported in the "2009 Red Book" ( NEA-IAEA, 2010).

[NA, data not available; $\mathrm{kgU}$, kilograms uranium metal]

\begin{tabular}{|c|c|c|c|c|c|}
\hline \multirow{2}{*}{ Country } & \multirow{2}{*}{\multicolumn{2}{|c|}{$\begin{array}{c}\text { Prognosticated resources } \\
\text { Cost ranges }\end{array}$}} & \multirow{2}{*}{\multicolumn{3}{|c|}{$\begin{array}{c}\text { Speculative resources } \\
\text { Cost ranges }\end{array}$}} \\
\hline & & & & & \\
\hline Brazil & 300.0 & 300.0 & NA & 500.0 & 500.0 \\
\hline Canada & 50.0 & 150.0 & 700.0 & 0.0 & 700.0 \\
\hline Chile & NA & 1.5 & NA & 3.2 & 3.2 \\
\hline Czech Republic & 0.2 & 0.2 & 0.0 & 179.0 & 179.0 \\
\hline Denmark $^{(a)}$ & 0.0 & 0.0 & 50.0 & 10.0 & 60.0 \\
\hline Germany & 0.0 & 0.0 & 0.0 & 74.0 & 74.0 \\
\hline Greece $^{(a)}$ & 6.0 & 6.0 & 0.0 & 0.0 & 0.0 \\
\hline Hungary & 0.0 & 18.4 & NA & NA & NA \\
\hline India & NA & 50.9 & NA & 17.0 & 17.0 \\
\hline Kazakhstan & 280.0 & 300.0 & 500.0 & NA & 500.0 \\
\hline Mexico $^{(a)}$ & NA & 3.0 & NA & 10.0 & 10.0 \\
\hline Mongolia $^{(a)}$ & 0.0 & 0.0 & $1,390.0$ & NA & $1,390.0$ \\
\hline Niger $^{(a)}$ & 14.5 & 24.6 & NA & NA & NA \\
\hline Peru & 6.6 & 6.6 & 19.7 & 0.0 & 19.7 \\
\hline Portugal & 1.0 & 1.5 & NA & 0.0 & NA \\
\hline Romania $^{(a)}$ & NA & 3.0 & 3.0 & 0.0 & 3.0 \\
\hline Russian Federation & 276.5 & 276.5 & 714.0 & 0.0 & 714.0 \\
\hline Slovenia & 0.0 & 1.1 & NA & NA & NA \\
\hline South Africa & 34.9 & 110.3 & NA & $1,112.9$ & $1,112.9$ \\
\hline Ukraine & 4.0 & 11.3 & 120.0 & 135.0 & 255.0 \\
\hline United States $^{(\mathrm{b})}$ & 839.0 & $1,273.0$ & 858.0 & 482.0 & $1,340.0$ \\
\hline Uzbekistan $^{(a)}$ & 56.3 & 85.0 & 0.0 & 134.7 & 134.7 \\
\hline
\end{tabular}

*Undiscovered resources are reported as in-situ resources.

**Totals may not equal sum of components due to independent rounding.

${ }^{(a)}$ Not reported in 2009 reponses, data from previous Red Book.

(b) The United States does not report inferred or prognosticated resources. 


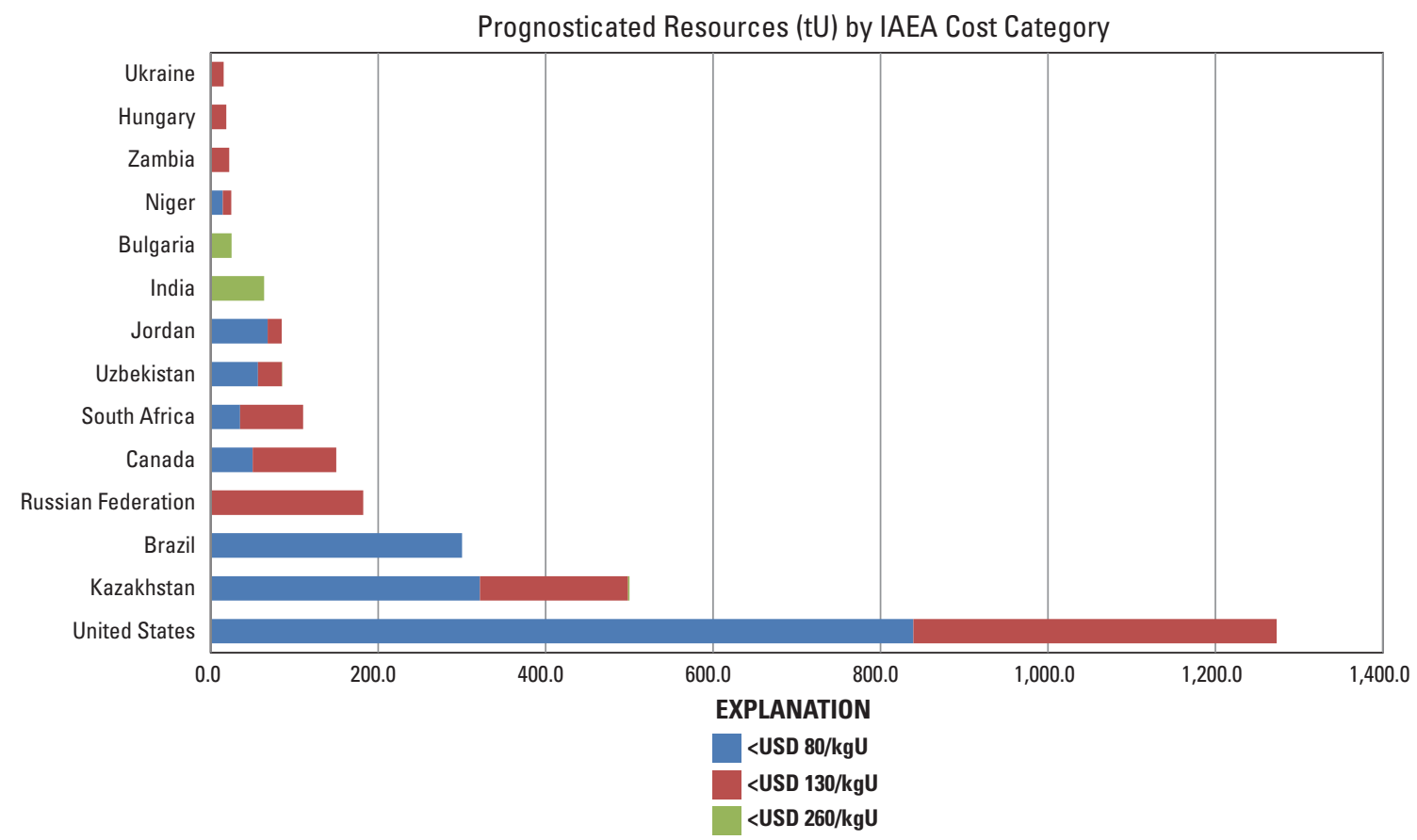

Figure 14. Prognosticated resources of countries reported as having more than 11,000 tU. From NEA-IAEA (2010).

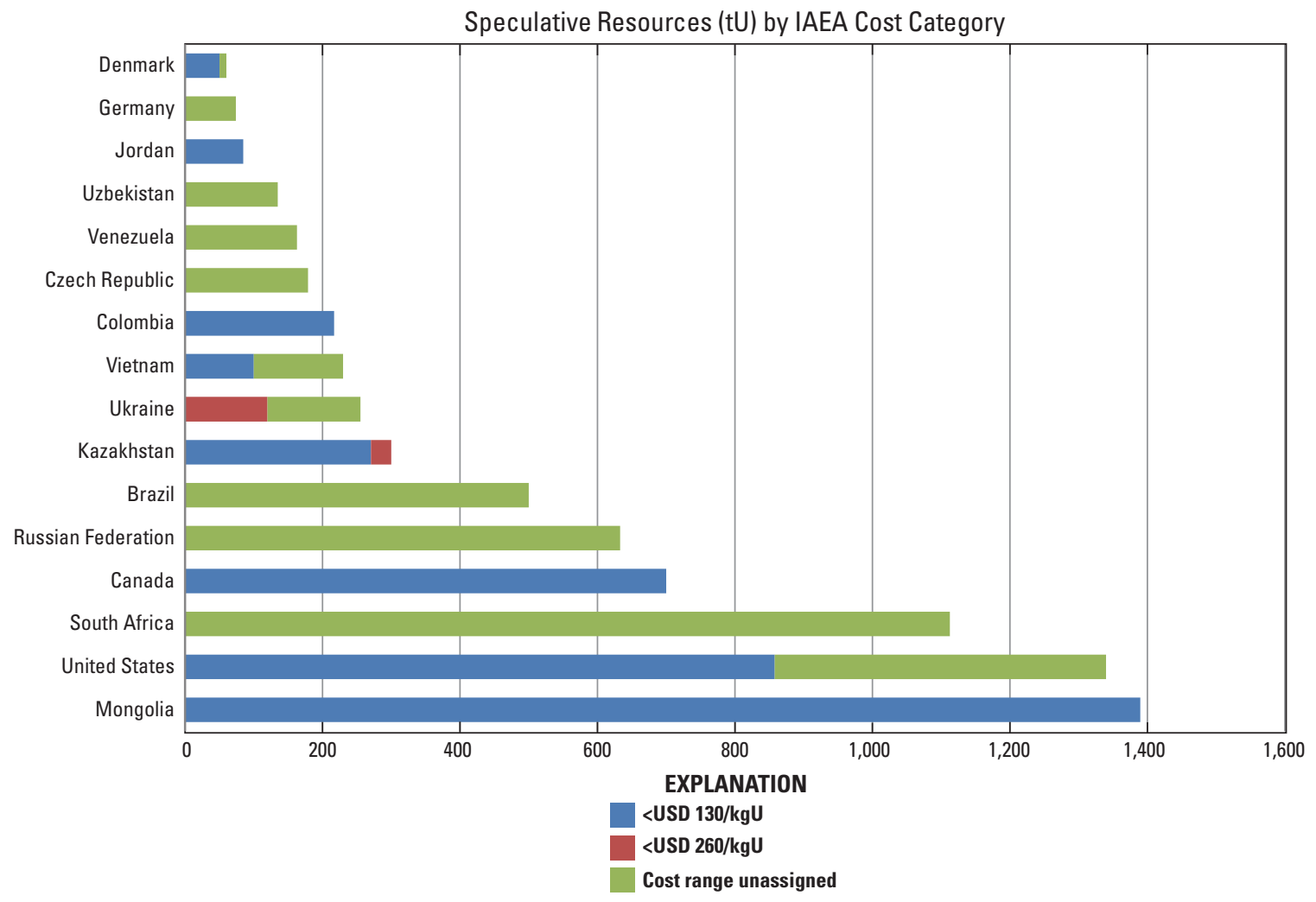

Figure 15. Speculative resources for countries reporting more than 60,000 tU. Data from NEA-IAEA (2010). 
Resources classified as undiscovered should be considered conjectural because the methodology and uncertainties of many undiscovered resource estimating techniques are poorly understood. For this reason, reliance upon undiscovered resources in developing energy policy should be done cautiously. Intensive exploration efforts will be required to move these resources into RAR categories in order to conduct prefeasibility and feasibility studies that could lead to mining.

Historically, the infusion of expenditures for exploring resources yielded a fairly predictable increase in the identification of RAR. Past periods of intense exploration, such as during the 1940s and 1970s, caused by increased demand, led to defining resources in excess of market requirements. Although increased expenditures for exploration uncovered new resources historically, such investment in the 21 st century may not yield similar finds. Many of the more easily identified deposits have been discovered and developed, whereas potential deposits are expected to be deeper and to require more innovative exploration techniques to delineate them, as well as more time, expense, and drilling.

\section{Production Capacity}

The known nominal or licensed production capacity of currently (during 2010) producing properties is 75,984 tU/yr, slightly greater than the current consumption of $68,971 \mathrm{tU} / \mathrm{yr}$. However, production in 2010 at 53,633 tU, was 70 percent of capacity. Disruptions in large mining operations are not uncommon, and the NEA reports that world production has never exceeded 89 percent of production capacity (Nuclear Energy Agency, 2006). Because mines never produce at or above production capacity for their entire mine life, when predicting future capacity, licensed capacity should be considered a maximum potential capacity.

Proposed mining capacity for developing mines is not always reported. Twenty six of the 74 developing mines reported in table 4 do not have an associated proposed production capacity that has been reported. Analysis of the proposed capacity for those mines for which information is available shows that a yearly minimum production rate of 52,741 tU has a good chance of being developed within the next 5 years.

\section{Uncertainties in Current and Future Production}

\section{Mine Floods and Accidents}

Current world uranium supply from primary sources is dominated by a few large mines. If there are technical difficulties at any of these large mines, the impact on uranium supply could be profound. At the McArthur River mine, which accounted for 15 percent of world production in 2009, a flood in 2003 halted production for 4 months delaying production of 1,300 tU. If flooding had not been quickly brought under control, the mine would have been closed for at least a year, according to Ux Consulting Company LLC (2010). The nearby Cigar Lake mine was flooded in 2006, delaying startup until at least 2013, and delaying production of an estimated $7000 \mathrm{tU} / \mathrm{yr}$. Production at Olympic Dam, the fifth largest uranium producer worldwide in 2009, was interrupted that same year by an ore haulage accident, which forced the mine to work on a limited capacity from October 2009 to July 2010, and reducing production by an estimated 1,600 tU (Ux Consulting Company LLC, 2010).

\section{The Influence of Infrastructure on Mine Development and on Definition of Resources}

Mine life for the producing mines is difficult to predict. Some operating mines, such as Rabbit Lake in Canada, may soon close if new RAR are not identified. At the other end of the spectrum, Olympic Dam was planning a major expansion that would have extended mine life to 2032, until it announced deferment of these plans in August, 2012.

The availability of local infrastructure can have a strong impact on identifying new RAR at an operating mine site. If existing infrastructure is adequate to support an operating mine, RAR are likely to grow and the life of the mine will be extended. At the Rabbit Lake mine in northern Saskatchewan, Canada, considerable infrastructure was developed to exploit the original 15,770 tU identified at this deposit in 1968. Incremental exploration followed by expansion along the mineralized trend have quadrupled the original capacity of this resource, expanding it to $68,467 \mathrm{tU}$ and extending mine life 27 years beyond the original projected closure.

If infrastructure is lacking, identified deposits will go unmined. Only one uranium mill is currently operating in the western United States, the White Mesa Mill in southeastern Utah, owned and operated by Energy Fuels. Active mines in the Uravan mineral belt of Colorado and Utah, the oldest mining area in the United States, and mines in the Arizona Strip district in Arizona must ship their ore to White Mesa for processing. Development of RAR of more than 14,000 tU on the Colorado Plateau and of RAR of 2,500 tU in the Arizona Strip is strongly influenced by whether this ore will have access to economic milling.

Exploitation of the largest uranium deposit in the world in Australia, BHP Billiton's Olympic Dam in Australia, depends on the development of extensive infrastructure, including building a desalination plant at the Indian Ocean and piping water approximately 300 kilometers (km) (186 miles (mi)) to the mine site in order to provide adequate water to expand the mine. The 2012 decision to postpone development of this resource (ABC News, 2012) illustrates how strongly resource development depends on adequate infrastructure. 


\section{Largest Corporate Entities and Holdings}

Approximately 25 companies are producing uranium worldwide. Of these companies, the top fourteen provided 91 percent of mined uranium in 2010. Major world uranium producers are Areva NC (Areva), the Cameco Corporation (Cameco), KazAtomProm , Rio Tinto, Atomredmetzoloty OJSC (ARMZ), Navoi Mining and Metallurgy Combinat (Navoi), BHP Billiton, Paladin Energy Ltd. (Paladin), and Uranium One Inc. (Uranium One) (Ux Consulting LLC, 2010; World Nuclear Association, 2011b). Distribution of uranium production among the top companies in 2010 is shown in figure 16.

Ux Consulting LLC predicts that it is likely that Areva, ARMZ (now ARMZ/Uranium One), BHP Billiton, Cameco, KazAtomProm and Rio Tinto will maintain a large market share of production to 2020. Projections show that Areva's production will remain relatively constant at about 20 percent of world supply. Cameco's share will fall slowly through 2020 to about 13 percent. KazAtomProm is expected to remain relatively flat, falling slightly to 12 percent by 2020 , and ARMZ is expected to fall significantly to 5 percent by 2020 , although their 2010 acquisition of Uranium One (which is projected to have 6 percent of the world market by 2020) will bolster production. Rio Tinto is expected to fall in share to less than 10 percent, and BHP Billiton is expected to fall to 5 percent.

Areva has the largest geologically defined resource base. Next in that category are BHP Billiton, KazAtomProm and Cameco (fig. 17). Rio Tinto is mining resources at

2010 World Production by Company

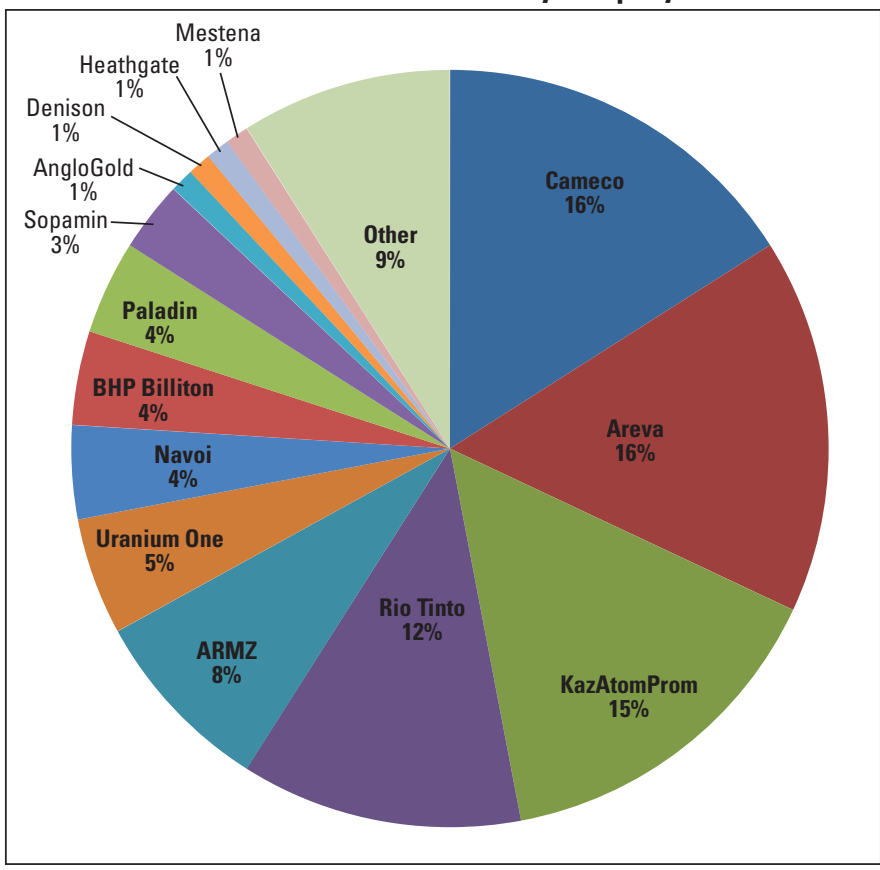

Figure 16. Uranium production by company in 2010. Data from the World Nuclear Association, (2011b).
Distribution of Uranium Resources Among the Top Nine World Uranium Producers in 2010

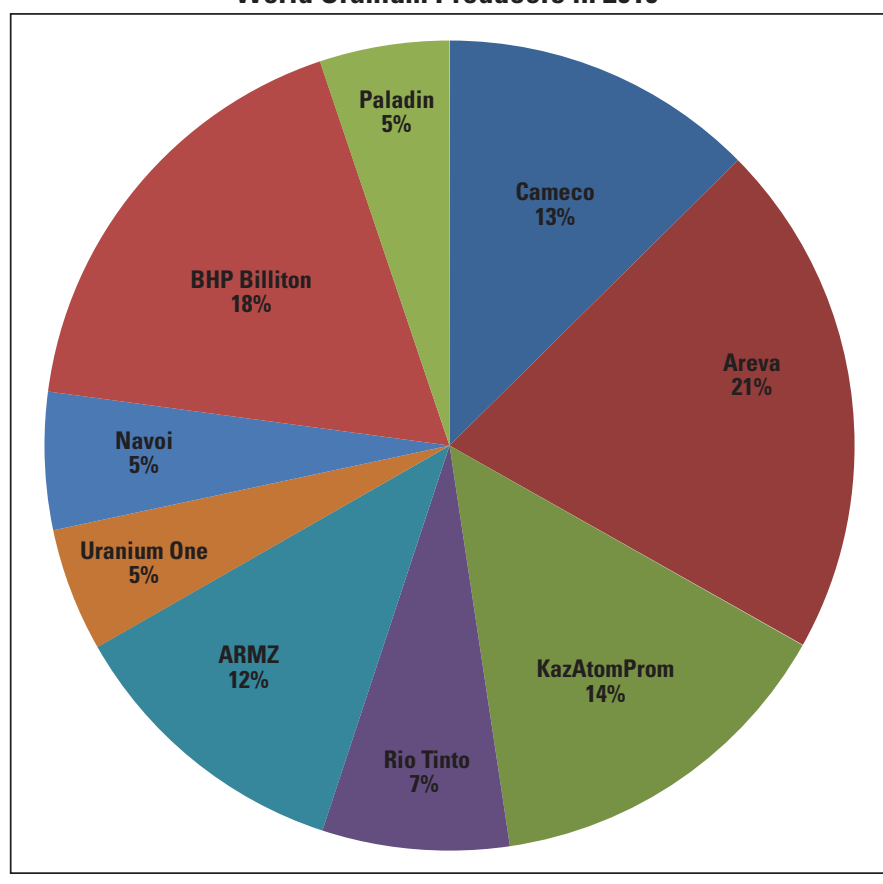

Figure 17. Distribution of resources among the top 9 world uranium producers in 2010. Data from Ux Consulting Company LLC (2010).

the most rapid pace, followed by Cameco, Uranium One, KazAtomProm, Navoi, Areva, Paladin, and ARMZ. The rapid rate at which Rio Tinto is depleting its resource is related to the ages of its two producers, Ranger and Rossing, both of which are reaching the end of their effective mine lives. The two large ISL producers in the world market, KazAtomProm and Uranium One, are depleting RAR at a relatively rapid pace due to the nature of ISL mining, which can be brought online quickly and operates for a relatively short period of time. Cameco's production relies heavily on their properties in the Athabasca Basin of Canada, where uranium can be mined rapidly due to the high-grade nature of the ore. BHP Billiton's Olympic Dam mine is being depleted at a low rate because it is a large, low-grade deposit.

\section{Long-term Demand and Supply Projections}

\section{Projected Production of Supply, by Country}

Uranium production from Kazakhstan is expected to increase in response to the aggressive marketing and development of resources by KazAtomProm, the short lead-time for development, the low cost of infrastructure required for ISL mines, and this country's large economic RAR (fig. 18, 19). 


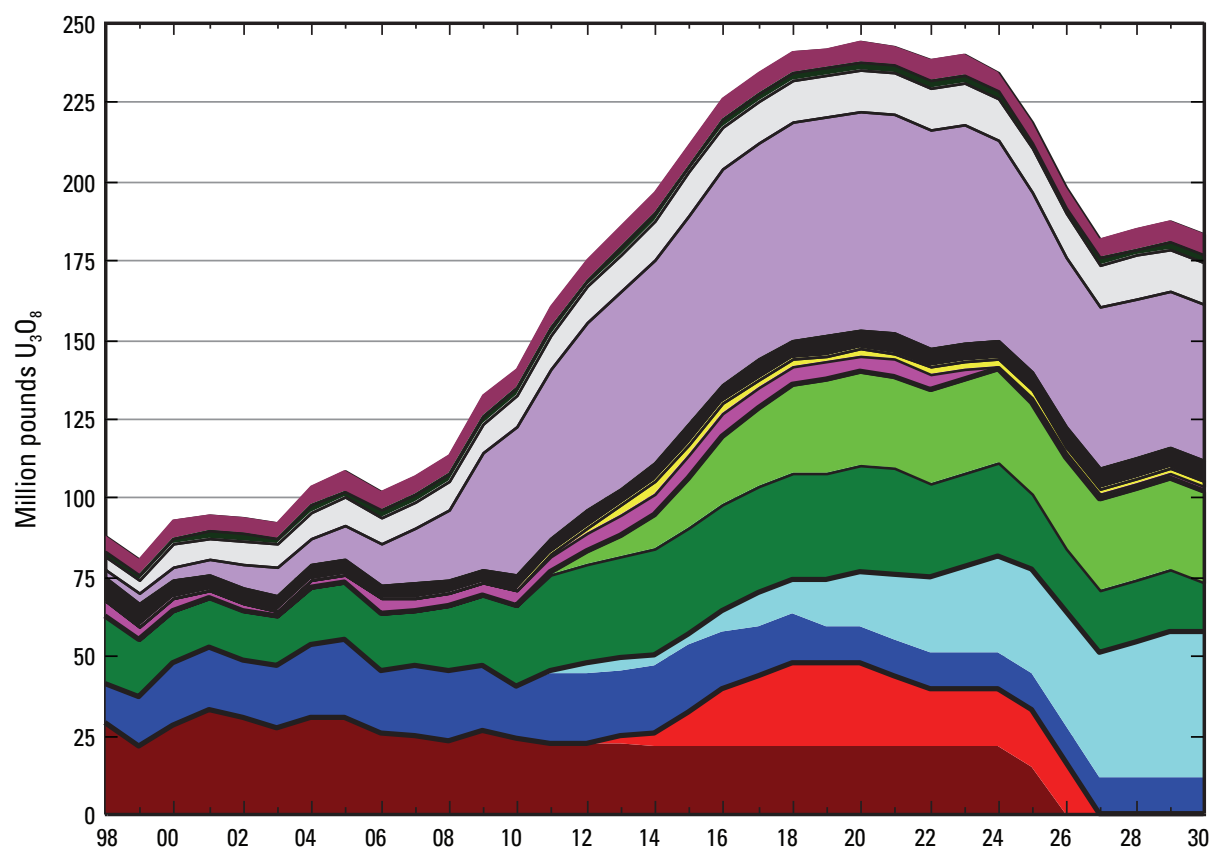

EXPLANATION

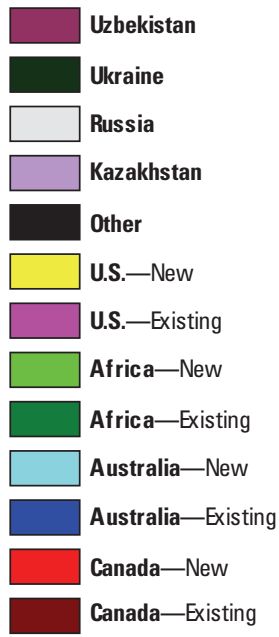

Figure 18. Existing uranium production and projected trends in production worldwide, 1998-2030. From Ux Consulting Company LLC (2010), reproduced with permission.

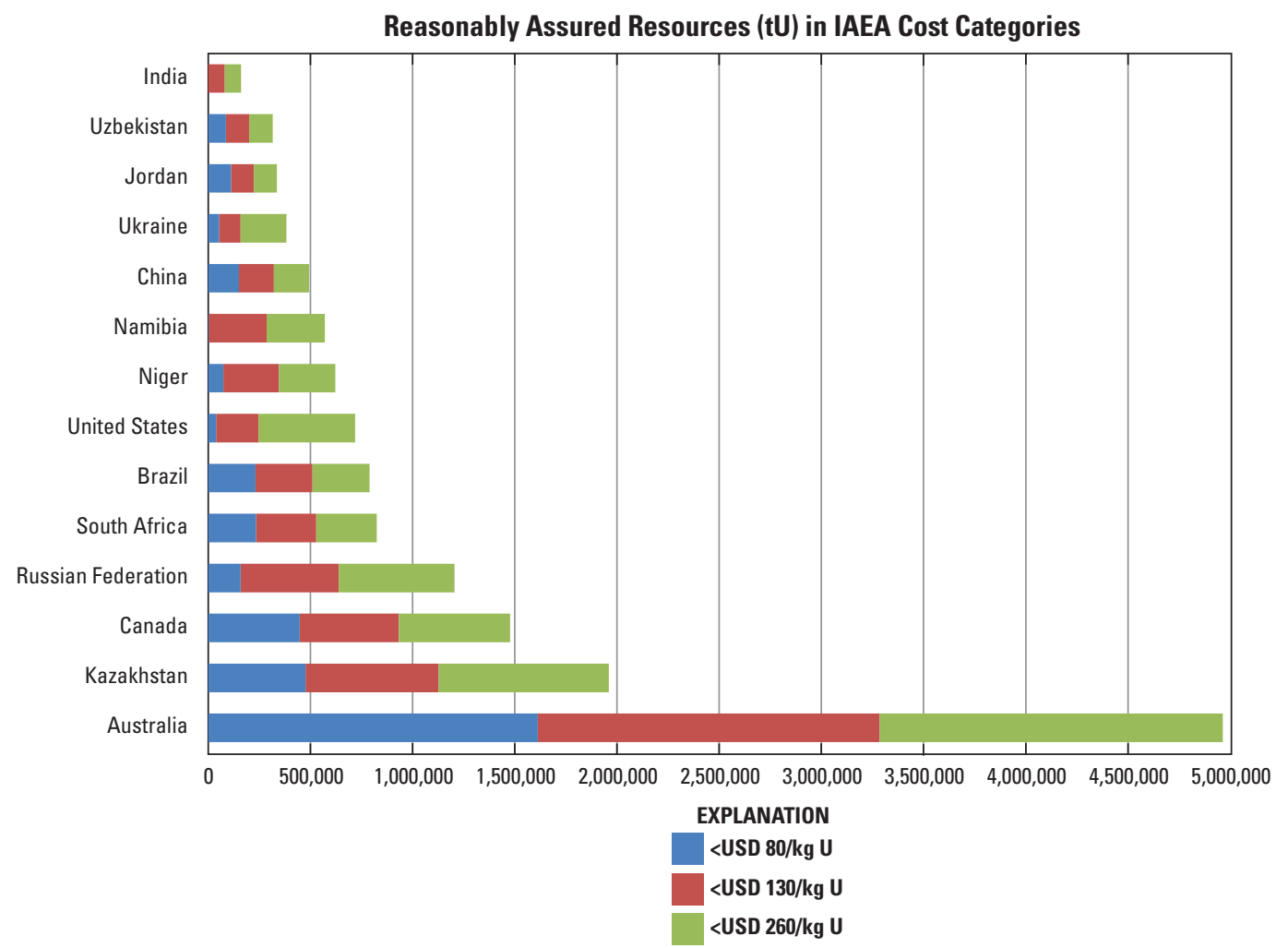

Figure 19. Distribution of reasonably assured resources (RAR) in Nuclear Energy Agency (NEA) cost categories for the most resource-rich countries. Data from NEA-IAEA (2010). 
Fourteen operating mines should continue to produce, joined by two new mines. The rate at which production increases in Kazakhstan depends, in part, on the rate at which the regional infrastructure develops and recent rapid increases may not be sustainable in the future. In Australia, existing deposits, such as Ranger, should produce significantly less uranium, but large new properties, such as Yeelerie, Olympic Dam, Ranger Deeps, and the smaller ISL properties-Four Mile and Honeymoon-may more than make up for mines that are closing, or for those whose production is expected to decrease. New deposits from Africa, in particular from Niger (Imouraren) and from Namibia (Trekkopje), could bring a great deal of production online. Namibia's production from existing mines (notably, in Langer Heinrich and in Rossing) continues. In Canada, some of the largest producing mines may be depleted (McArthur River, Rabbit Lake), and, although new planned mines (Midwest, Cigar lake) should make up for this production, their contribution to world supply is predicted to be relatively short-lived. Production from other countries, including Uzbekistan, Russia, Ukraine, and others, is expected to continue steadily into the future. Uranium production in the United States is minor, providing less than 10 percent of domestic demand, and properties now being developed are relatively small ISL mines that are fairly short lived (Ux Consulting Company LLC, 2011).
Continued growth in uranium production worldwide depends in part on sustained prices that support extraction of resources in the higher cost categories (fig. 19).

\section{Projections to 2035}

On the basis of data supplied from member countries, the NEA reports that growth in global installed nuclear capacity is projected to grow from 372 gigawatts of electricity (GWe) net in early 2009 to between 511 GWe net (low case) and 782 GWe net (high case) by the end of 2035 (NEA-IAEA, 2010). Projected uranium requirements vary considerably by region (fig. 20). Most of the projected growth is in East Asia, where increases in annual uranium requirements are forecast to range from 120 percent to 180 percent more than 2009 requirements. By contrast, annual requirements in North America are expected to range from a 25-percent decrease in the low case to a 55-percent increase in the high case. The European Union's requirements are projected to range from a 15 -percent decline to an increase of more than 25 percent by 2035 .

Projected nuclear capacity translates to increased global reactor-related uranium requirements that range from 227 million pounds $\mathrm{U}_{3} \mathrm{O}_{8}$ per year $(87,370 \mathrm{tU} / \mathrm{yr})$ to 359 million pounds $\mathrm{U}_{3} \mathrm{O}_{8}$ per year $(138,165 \mathrm{tU} / \mathrm{yr})$, assuming a tails assay

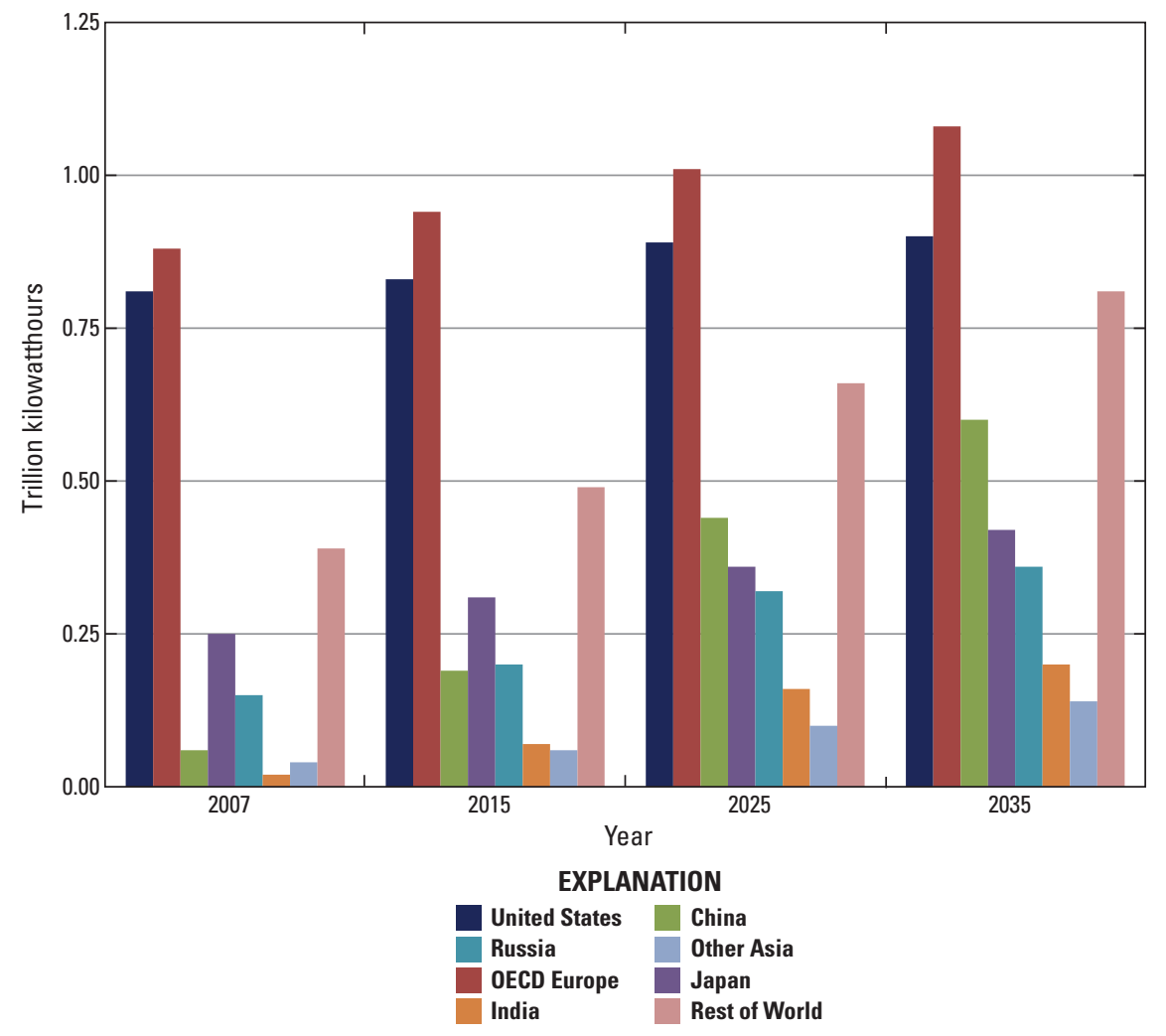

Figure 20. World net electricity generation from nuclear power, by region, 2007-2030 (Energy Information Administration, 2010b). 
of 0.30 percent, by the end of 2035 (fig. 21). This represents an increased uranium requirement of 40 percent in the low case, and 120 percent in the high case (NEA-IAEA, 2010).

Primary production of uranium, that is, actual mining of uranium, accounted for 50 to 60 percent of world requirements during 2006-2011, with secondary sources providing the remainder. Secondary sources, especially the source that will diminish after 2013 when the United States/Russian program, Megatons to Megawatts, expires, will require an increase in uranium from other sources in the near term to meet future demand (NEA-IAEA, 2010).

Sixty percent of the 3.5 million tU mineable for less than USD $130 / \mathrm{kgU}$ identified worldwide is either in production, or scheduled to come online by 2015 . If uranium prices trend higher, an additional 479,600 tU identified in the higher cost categories worldwide should become economic (fig. 13). Mining of inferred resources reported by NEA - those classified as less well constrained geologically - could add another 2.3 million tU of economic resources to world supply (NEA-IAEA, 2010). With no growth in demand, these resources would fulfill current requirements: inferred resources for an additional 27 years, and currently uneconomic resources for an additional 6 years. Coupled with demonstrated resources, NEA's reporting predicts that RAR in the identified and in the inferred categories would satisfy current demand for 70 years. However, the inferred categories are poorly understood and could be substantially different from current estimates.

NEA estimates that, as of 2009 , existing and committed uranium mine production covers global demand through 2021 in the high-case, and until 2024 in the low-case growth scenarios. Assuming that plans are successful for significant expansion of existing mines and for new production centers, high-case demand requirements will be met until 2029, and low-case requirements until after 2035 (NEA-IAEA, 2010).

The Ux Consulting Company LLC publishes projections of uranium supply determined by detailed examination of development timelines for existing mines and for processing facilities, for planned and for potential mines, and for secondary supplies. Their projections indicate that supply will increase 13 percent to 159 million pounds $\mathrm{U}_{3} \mathrm{O}_{8}(61,158 \mathrm{tU})$ by 2011 , and that the increase will range from 210 to 224 million pounds $\mathrm{U}_{3} \mathrm{O}_{8}$ (from 80,775 to $86,160 \mathrm{tU}$ ) by 2020 . In any scenario for nuclear growth, future projections based on high- and on low-growth scenarios show that secondary uranium supplies are required to fuel the world nuclear power reactor fleet (fig. 22). Projections by both NEA and the Ux Consulting Company indicate that mine development is proceeding too slowly to fully meet requirements for an expanded nuclear power reactor fleet, and imbalances in supply and demand may occur.

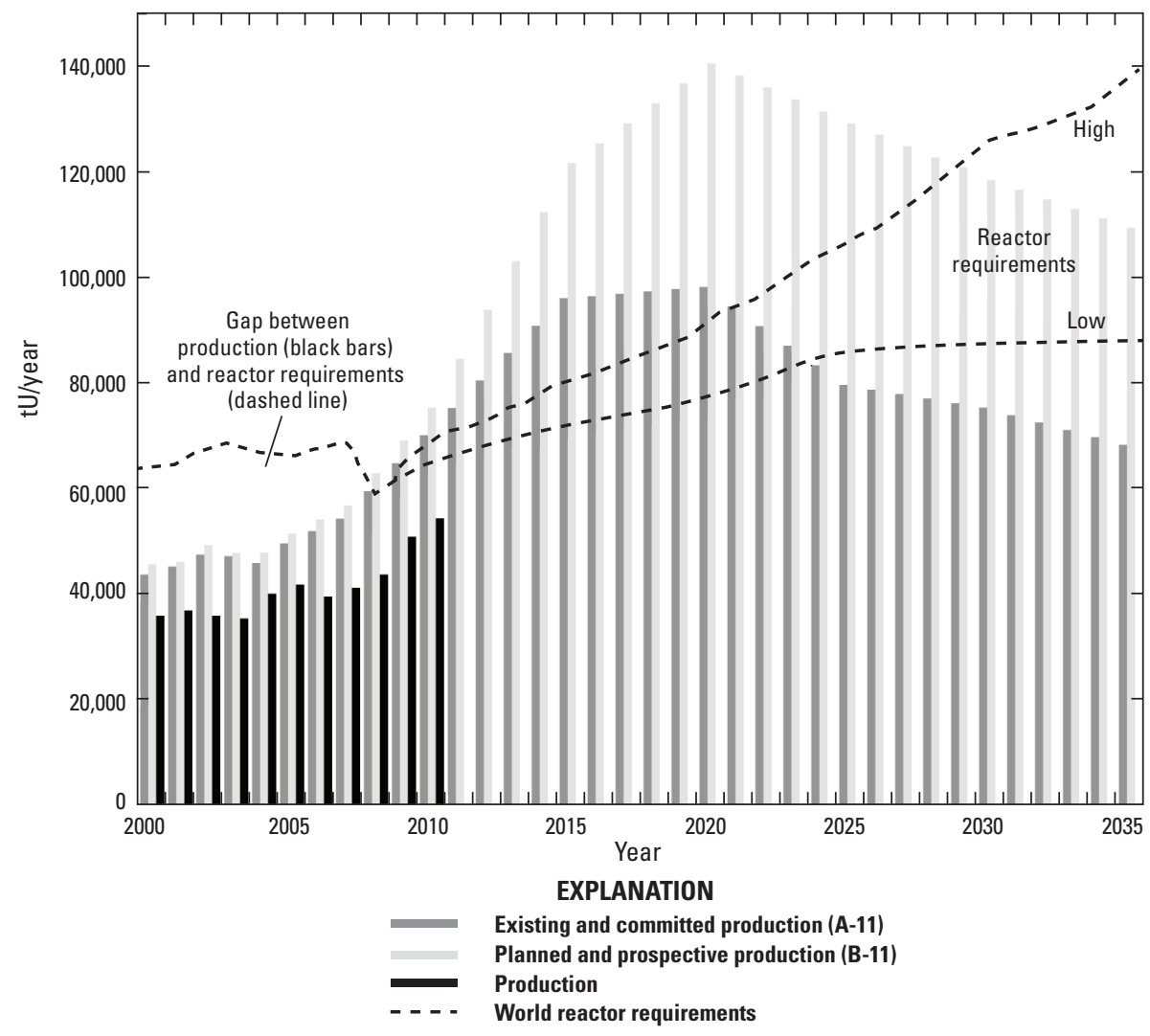

Figure 21. Scenarios for production of and requirements for uranium, 2011-2035. From NEA-IAEA (2010), reproduced with permisison. 


\section{Projections beyond 2035}

The World Nuclear Association (WNA), an international private-sector organization, is one of the few organizations that projects global demand for nuclear power to 2100 . Figure 23 illustrates the WNA upper and lower trajectories for growth of nuclear power. The WNA provides an analysis of upper and lower trajectories for each country that has a nuclear program. The lower trajectory reflects the minimum anticipated nuclear capacity of $\sim 2,050 \mathrm{GW}$, and the upper trajectory reflects a full policy commitment to nuclear power that is as much as $11,000 \mathrm{GW}$ of capacity. The zone between the upper and lower trajectories is considered the likely domain in which growth will occur, and the trajectories are considered boundaries rather than low or high cases. The WNA takes the optimistic view that uranium supply will not be an obstacle to future growth, and that the combined factors of successful exploration, new mining technologies, reprocessing of fuel, and use of Generation IV reactors, will ensure an ample supply of nuclear fuel well into the 22 nd century. WNA does concede that delays in bringing RAR into production are increasingly challenging (World Nuclear Association, 2011a).
The NEA takes a more cautious view of the timely development of nuclear fuel supplies. In the 2009 "Red Book", the NEA forecasts adequate Identified Resources (Reasonably Assured Resources plus Inferred Resources) to supply reactors for the next 100 years, if 2008 consumption rates (154 million pounds $\mathrm{U}_{3} \mathrm{O}_{8}$ per year $\left.(59,065 \mathrm{tU} / \mathrm{yr})\right)$ are projected into the future. This forecast does not take into account projected growth in capacity (NEA-IAEA, 2010). If all conventional resources are included (Identified Resources plus Speculative and Prognosticated Resources), then the supply would last 300 years, through 2410, using the 2008 consumption rate. In the 2009 "Red Book" and in related publications, the NEA emphasizes that potential problems in the supply chain do not include the resource base, but instead lie with factors that affect timely development of RAR. For example, expanding the resource through exploration and through development depends on a robust market that also provides the required capital and financing to bring mines online. Other factors that influence uranium resource development include the region's regulatory climate for mining, its established regulations and safeguards for safe mining development and operations, an adequate infrastructure, a skilled workforce, and the region's ability to retain

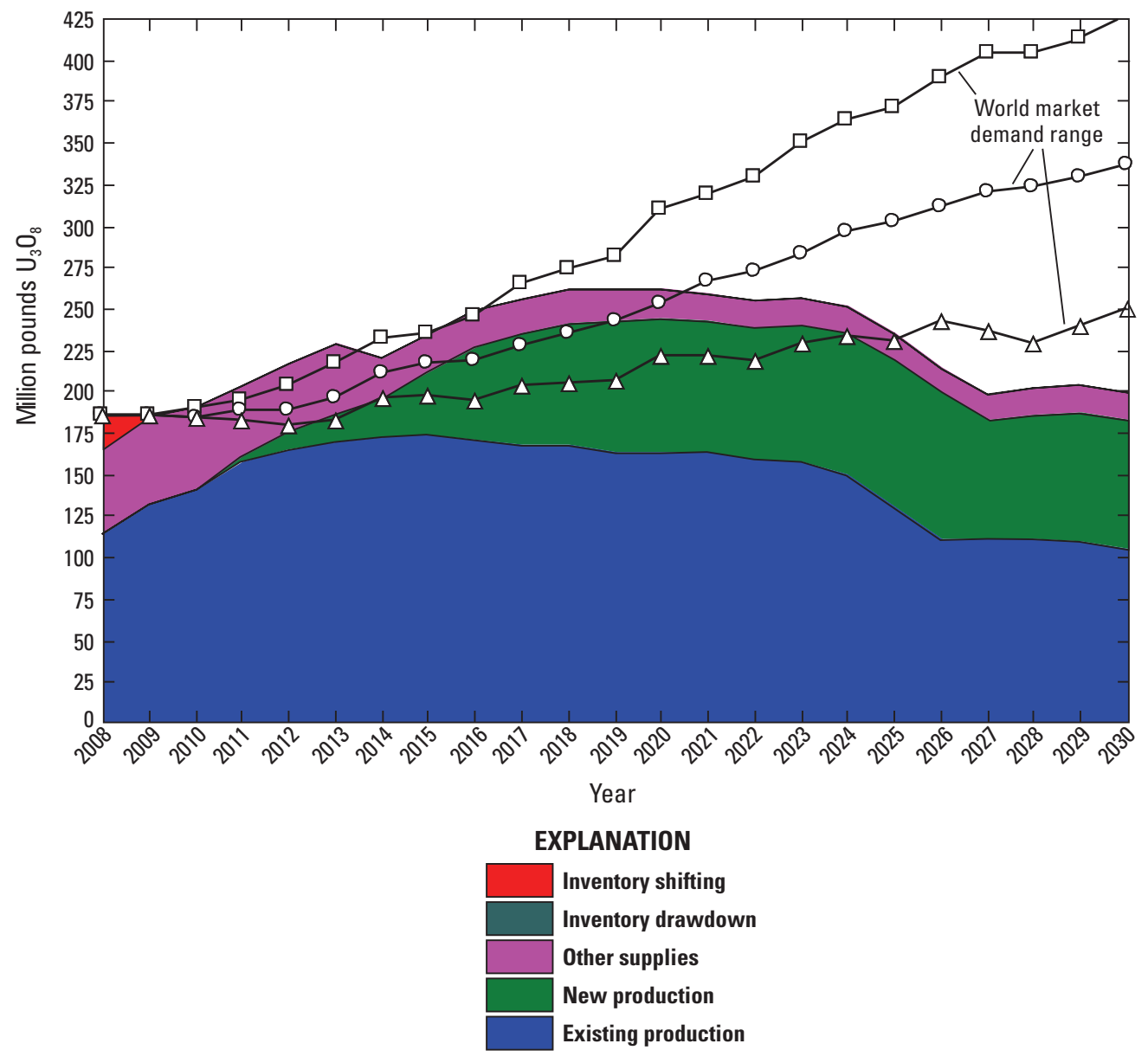

Figure 22. Actual and projected world trends in growth of market demand and increase of supply, 2008-2030. From Ux Consulting Company LLC, (2010), reproduced with permission. 


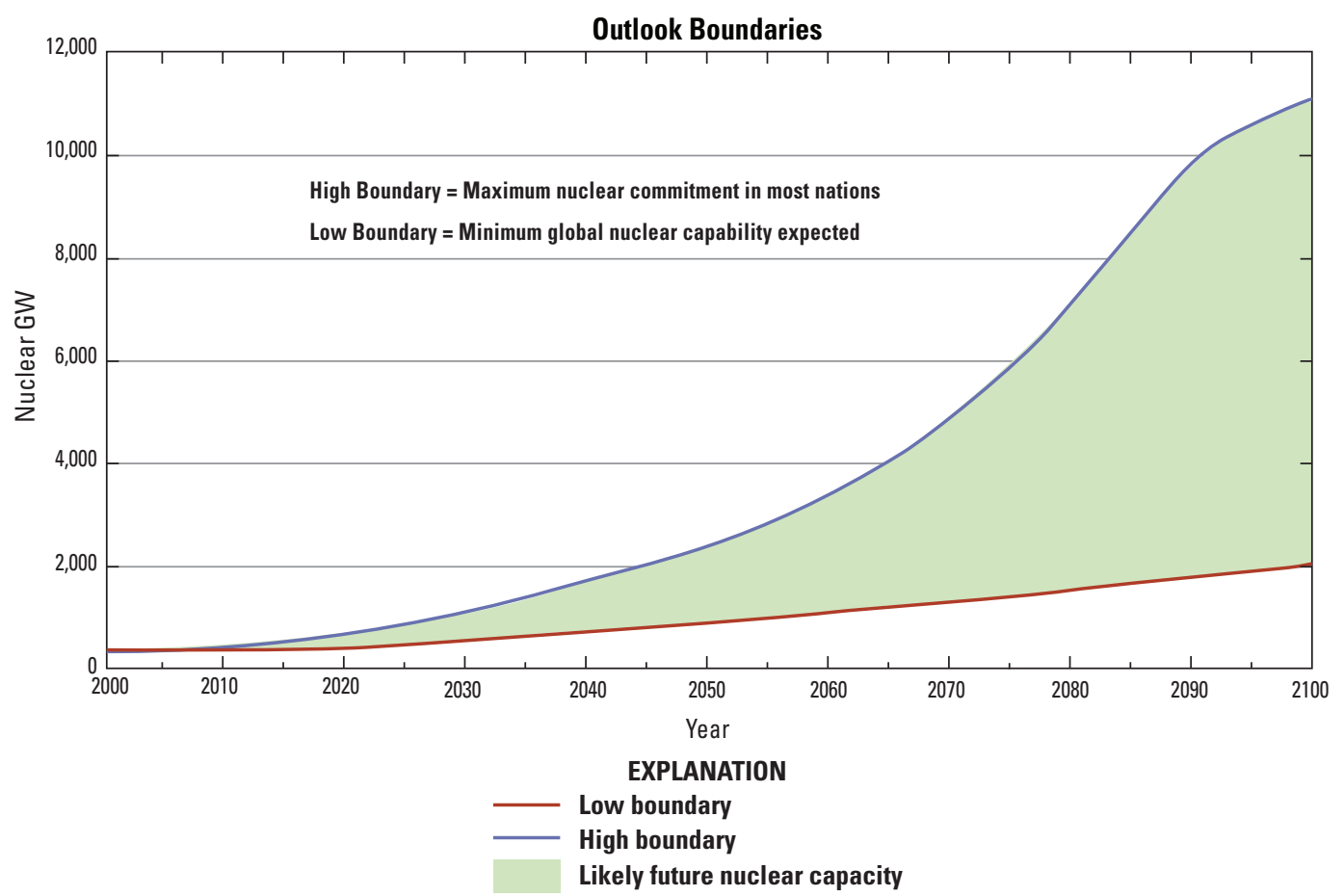

Figure 23. World Nuclear Association projections for future nuclear capacity worldwide, to 2100. From World Nuclear Association (2011b), reproduced with permission.

financiers willing to wait many years for a return on their investment. The single most important factor identified for ensuring that mines are developed in a timely fashion is the strength of the market. In uncertain financial times, a sustained and strong uranium market is far from guaranteed.

Most projections of uranium supply and demand focus on primary production from mines that extract uranium as a primary product or byproduct, and on secondary sources to fulfill demand. Although higher uranium costs may stimulate exploration and new discoveries, projections to 2100 and beyond would not be complete without evaluating the potential uranium contribution from unconventional resources such as uraniferous phosphates, black shales, and seawater. Uranium is elevated significantly above crustal abundance in both black shale and in phosphate deposits, and the economic extraction of uranium from these sources is being actively investigated. The extraction of uranium from phosphates is receiving the most attention, because it can potentially tap into a vast resource that may exceed 1.9 billion tU (IAEA, 2010). The environmental benefit of removing uranium from phosphates that are primarily mined for fertilizer makes this potential uranium source increasingly attractive. Uranium in black shales is also a large resource capable of yielding an estimated 1 billion $\mathrm{tU}$. The benefit of developing techniques for removing uranium from existing polymetallic mines has become the focus of some large uranium producers. Uranium extraction from seawater is still in the research stage, and is currently not even close to being economic, with reported production costs reaching USD 700/ $/ \mathrm{ggU}$ (NEA-IAEA, 2010).

\section{Summary}

This report addresses the question: Is there enough uranium in the worldwide resource base to meet the cumulative worldwide requirement for the decades through 2035? Much of the emphasis of the report rests therefore on the physical quantities of uranium resources, including a fairly detailed comparison of what is known about supply and what is known about likely demand. The report concludes that identified uranium resources appear to be adequate to serve needs into the 25 -year future, but that delays in developing these resources may create periodic imbalances.

Mine production may not keep pace with demand because (1) the time between the delineation of a deposit and the time when it is first mined can lag by as much as 15 years ; (2) exploration in some regions is insufficient to keep production growing at reasonable rates; (3) infrastructure inadequate to support the economic milling of the ore may limit extraction; and (or) (4) future exploratory drilling may reveal less resource than is currently estimated, especially in the categories of mines that are less geologically certain.

It is also possible, however, that the report has erred in the direction of being too conservative. Only a few of the many technological changes and substitutions that are likely to occur on the supply and the demand sides of the market have been incorporated into mining procedures. In many cases, additional resources are discovered as mining proceeds. Although this report describes a few cases where uranium mining uncovered much larger resources nearby, it would be too speculative to include this kind of growth in estimates of reserve. 
In the short term, an analysis of production centers shows that, since 1990, uranium has been under produced when compared to demand. The shortfall has been made up from stockpiles, from recycling, and from the United States/Russian HEU-LEU program (to end in 2013). Although worldwide reporting restrictions make it difficult to determine remaining uranium inventories, it appears that these stockpiles are being depleted, and that primary supply is coming online more slowly than demand is expanding.

Although resources identified in the existing and developing supply are sufficient to fuel existing reactors at current rates of consumption for at least 30 years (to 2040), capacity does not appear to be being developed at a fast enough rate to keep up with demand. Projections more than about 20 years into the future (to 2030) are problematic because whether uranium resources will be identified depends on the price of uranium, which in turn drives both exploration and development. If, however, we assume that NEA's estimates of world supply are accurate, so that higher-cost uranium deposits and those that are not geologically well constrained (inferred resources) are included in estimates of supply, then, at current rates of consumption, supply can keep pace with demand for 70 years (to 2080). This evidence-based conclusion does not take into account the future growth worldwide of nuclear power.

Predictions that show expansion of nuclear capacity as ranging from 40 to 120 percent of current capacity by 2035 will strain capacity for developing supply. NEA estimates that operating and developing mines will be capable of satisfying only 80 percent of demand for the low-growth scenarios, and 50 percent of demand for the high-growth scenarios. Recognizing this potential shortfall, some utilities are buying into primary supply at the mine site rather than relying on uranium suppliers or brokers.

Additional concerns include the possibility that the stability of future primary uranium supplies will decrease. More primary uranium will be supplied from Kazakhstan, Africa (Namibia, Niger), Australia, and Canada, with production from other countries remaining flat. Production in Australia is tied to the large Olympic Dam deposit, and Canada largely depends on the development of the Cigar Lake and the Midwest mines. The dependence of uranium supply on large individual uranium properties and countries adds uncertainty to estimates of future supply. Major producers Cameco, Areva, KazAtomProm, Rio Tinto, ARMZ/Uranium One, and BHP Billiton are expected to continue to maintain their large market share into the future.

Growth in nuclear capacity worldwide will put pressure on existing and identified supplies. Unless new large-capacity mines come online in the near future, prices are expected to rise, and this increase should at the same time stimulate additional exploration and make some unconventional resources more attractive. Long-term projections of uranium supply depend on the rate at which nuclear capacity expands.
As supplies tighten, utilization of secondary sources and of unconventional resources is likely to expand. Industry is beginning to develop some large mostly unexploited resources, including uranium in phosphates and in black shale deposits. In addition, secondary sources including uranium in enrichment tails are increasingly attractive. Exploration is expected to continue if uranium prices remain high, moving the reported 2.81 million $\mathrm{tU}$ of prognosticated, and the 7.5 million $\mathrm{tU}$ of speculative undiscovered resources into less hypothetical RAR categories. Although data are currently insufficient to allow accurate projections of the extent to which unconventional resources will contribute to the expansion of uranium supply into the future, careful monitoring of ongoing pilot projects and of expansion of capacity is warranted.

\section{Acknowledgments}

This paper benefited from reviews by and discussion with Robert Vance of the OECD Nuclear Energy Agency, and William Watson and Scott Sitzer (retired) of the DOE Energy Information Administration. The authors would also like to acknowledge Mark Hannon, who drafted the maps in appendix 1.

\section{References Cited}

ABC News, 2012, BHP shelves Olympic Dam as profit falls a third, August 22, accessed September 24, 2012 at: http:// www.abc.net.au/news/2012-08-22/bhp-billiton-profit-fallsa-third/4215638.

Areva NC, 2011, [Home page]: Areva Web site, accessed January 2011, at $h t t p: / / w w w$.areva.com.

Bakarzhiyev, Y.A., 2011, Recent developments in the field of uranium-Ukraine: Joint Nuclear Energy Agency/ International Atomic Energy Agency Group on Uranium, meeting, 47, Paris, France, November 2-4, 2011, presentation, 14 p.

Berkeley Resources Ltd., 2011, Home: Berkeley Resources Ltd. Web site, accessed January 2011, at http:// www.berkeleyresources.com.au/.

BHP Billiton, 2011, Uranium: BHP Billiton Web site, accessed January, 2011, at http://www.bhpbilliton.com/.

Bianchi, R.E., 2010, Update of raw materials activities in Argentina: Nuclear Energy Agency-International Atomic Energy Agency Group on Uranium, meeting, 45, Saskatoon, Canada, August 19-20, 2010, presentation, 29 p. 
Boytsov, A.V., 2010, Sustainable development of U production-Time challenge: Joint Nuclear Energy Agency/ International Atomic Energy Agency Group on Uranium, technical meeting, Saskatoon, Canada, 15 p.

Calvert, Tom, 2010, Recent developments-Canada: Joint Nuclear Energy Agency/ International Atomic Energy Agency Group on Uranium, meeting, 45, Saskatoon, Canada, August 19-20, 2010, presentation, Organisation for Economic Co-operation and Development Nuclear Energy Agency and International Atomic Energy Agency, 15 p.

Cameco Corporation, 2011, On the double-Keeping pace with uranium demand: Cameco Corporation 2010 annual report, 144 p. (Also available at http://www.cameco.com/ investors/financial_reporting/annual_reports/2010/.)

Chaki, Anjan, 2010, India country report: Joint Nuclear Energy Agency/ International Atomic Energy Agency Group on Uranium, meeting, 45, Saskatoon, Canada, August 19-20, 2010, presentation, 16 p.

Commonwealth of Australia, 2010, Australia's in situ recovery uranium mining best practice guide-Groundwaters, residues and radiation protection: [Australia] Department of Resources, Energy and Tourism, 23 p. (Also available at $h t t p: / / w w w . r e t . g o v . a u / r e s o u r c e s / D o c u m e n t s /$ Mining/10-4607_in\%20situ\%20uranium_31May.pdf).

Dahlkamp, F.J., 2010, Uranium deposits of the world: Berlin, Springer, v. 4, 2,400 p.

daSilva, L.F., 2010, Brazil, recent activities: Joint Nuclear Energy Agency/ International Atomic Energy Agency Group on Uranium, meeting, 45, Saskatoon, Canada, August 19-20, 2010, presentation Organisation for Economic Cooperation and Development-Nuclear Energy Agency \& International Atomic Energy Agency, 2 p.

Energy Fuels Inc., 2012, Home page: Energy Fuels Inc. Web site, accessed October, 2012 at: http://www.energyfuels.com/.

Energy Information Administration, 2009, Domestic uranium production report-Annual [2009]: U.S. Energy Information Administration, accessed January 2011 at http://www.eia.gov/cneaf/nuclear/dupr/dupr.html.

Energy Information Administration, 2010a, Domestic uranium production report-Quarterly, 4th quarter 2010: U.S. Energy Information Administration, accessed March 2011, at $h t t p: / / w w w . e i a . g o v / c n e a f / n u c l e a r / d u p r / q u p d . h t m l$.

Energy Information Administration, 2010b, International energy outlook 2010 with projections to 2035: U.S. Energy Information Administration Report no. EIA-0554, 195 p.
Energy Information Administration, 2010c, International energy statistics: U.S. Energy Information Administration database, accessed March 2011 at http://205.254.135.7/ cfapps/ipdbproject/iedindex3.cfm.

Energy Information Administration, 2010d, Uranium marketing annual report [2009]: U.S. Energy Information Administration, accessed April, 2010 at $h t t p: / / w w w . e i a . g o v / c n e a f /$ nuclear/umar/umar.html.

Energy Information Administration, 2011, Domestic uranium production report 2010: U.S. Energy Information Administration, 14 p., accessed May 2011 at $h t t p: / / 205.254 .135 .7 /$ uranium/production/annual/.

Greenland Minerals and Energy Ltd., 2011, [Home page]: Greenland Minerals and Energy Ltd. Web site, accessed January 2011, at http://www.ggg.gl/.

Hisatani, Koichi, 2010, Current status of nuclear industry and technology in Japan: Joint Nuclear Energy Agency/ International Atomic Energy Agency Group on Uranium, meeting, 45, Saskatoon, Canada, August 19-20, 2010, presentation, $7 \mathrm{p}$.

IAEA (International Atomic Energy Agency), 2009, World distribution of uranium deposits (UDEPO) with uranium deposit classification: Vienna, Austria, International Atomic Energy Agency IAEA-TECDOC-1629, $117 \mathrm{p}$.

IAEA (International Atomic Energy Agency), 2010, World distribution of uranium deposits (UDEPO): International Atomic Energy Agency database, accessed January-April, 2011, at http://infcis.iaea.org/.

Itamba, Helena, 2011, Developments in the field of uranium Namibia: Joint Nuclear Energy Agency/International Atomic Energy Agency Group on Uranium, meeting, 45, Saskatoon, Canada, August 19-20, 2010, presentation, 14 p.

Jones, Bryn, and Davidson, James, 2009, PhosEnergy—New age extraction of uranium from phosphoric acid, in International Atomic Energy Agency Uranium from unconventional resources technical meeting, August 2009, Vienna, Austria, International Atomic Energy Agency, 33 p.

Khan Resources Inc., 2011, Latest news: Khan Resources Inc. Web site, accessed April 2011, at http://www.khanresources.com/.

Marenica Energy Limited, 2011, Marenica Energy Limited is an Australian Stock Exchange listed company with its major focus being the discovery and development of uranium deposits: Marencia Energy Limited, accessed April 2011, at http://www.marenicaenergy.com.au/.

Mawson Resources Limited, 2008, Tåsjö uranium project: Mawson Resources Limited, accessed February 2011, at http://www.mawsonresources.com/s/Tasjo.asp 
McKay, Aden, and Carson, Leesa, 2010, Recent developments in Australia's uranium mining industry: Joint Nuclear Energy Agency/International Atomic Energy Agency Group on Uranium, meeting, 45, Saskatoon, Canada, August 19-20, 2010, presentation, 28 p.

Mega Uranium Mining Company, 2011, Uranium resources: Mega Uranium Mining Company, accessed February 2011, at http://www.megauranium.com/uranium_resources/.

MIT Energy Initiative, 2011, The future of the nuclear fuel cycle: Massachusetts Institute of Technology, 237 p. (Also available at http://web.mit.edu/mitei/research/studies/ nuclear-fuel-cycle.shtml.)

NEA-IAEA (Organization for Economic Co-operation and Development Nuclear Energy Agency and International Atomic Energy Agency), 2000, Uranium 1999-Resources, production and demand: Organization for Economic Cooperation and Development Publishing, $340 \mathrm{p}$.

NEA-IAEA (Organization for Economic Co-operation and Development Nuclear Energy Agency and International Atomic Energy Agency), 2006, Uranium 2005-Resources, production and demand: Organization for Economic Cooperation and Development Publishing, 388 p.

NEA-IAEA (Organization for Economic Co-operation and Development Nuclear Energy Agency and International Atomic Energy Agency), 2008, Uranium 2007-Resources, production and demand: Organization for Economic Cooperation and Development Publishing, $420 \mathrm{p}$.

NEA-IAEA (Organization for Economic Co-operation and Development Nuclear Energy Agency and International Atomic Energy Agency), 2010, Uranium 2009-Resources, production and demand, Organization for Economic Cooperation and Development Publishing, $456 \mathrm{p}$.

NECSA (South African Nuclear Energy Corporation), 2010, Uranium in South Africa-An industry update: Joint Nuclear Energy Agency/ International Atomic Energy Agency Uranium Group, meeting, 45, Saskatoon, Canada, August 19-20, 2010, presentation, 12 p.

Ngoupana, Paul-Marin, Felix, Bate, and Barker, Anthony, 2011, Areva suspends CAR uranium mine project: Thompson Reuters, November 3, accessed June 22, 2012, at http://af.reuters.com/article/commoditiesNews/ idAFL5E7M34T920111103.

Nuclear Energy Agency (NEA), 2006, Forty years of uranium resources, production and demand in perspective: Organization for Economic Co-operation and Development Publishing, $276 \mathrm{p}$.
Nuclear Energy Agency (NEA), 2008, Nuclear energy outlook 2008: Organization for Economic Cooperation and Development Publishing, $460 \mathrm{p}$.

Paladin Energy, Ltd., 2011, Paladin Energy Ltd.-The new energy on the market: Paladin Energy, Ltd. Web site, accessed June 22, 2012, at http://www.paladinenergy.com.au/.

Pool, T.C., and Ross, D.A., 2007, Technical report on the Arizona strip uranium project, Arizona, U.S.A.: Scott Wilson Roscoe Postle Associates Inc. technical report NI 43-101, prepared for Denison Mines Corporation, 116 p., accessed June 22, 2012, at http://www.denisonmines.com/content/ pdf/43-101_arizona_strip.pdf.

Puritch, Eugene, Hayden, Alfred, Partsch, Alexander, Harron, G.A., and Brown, F.H., 2010, Preliminary economic assessment on the Viken MMS project, Sweden: P \& E Mining Consultants Inc., EHA Engineering Ltd., and G.A. Harron \& Associates Inc. technical report NI 43-101 and 43-101F, prepared for Continental Precious Minerals Inc., 122 p., accessed June 22, 2012, at http://www.czqminerals.com/ assets/pdf/viken_pea_report_oct_2010.pdf.

Rigby, Neal, Muller, S.C., Hollenbeck, Patrick, Stryhas, Bart, Daviess, Frank, and Kurrus, Andy, 2010, Technical report on resources - Uranium Energy Corp. Palangana ISR uranium project, deposits PA-1, PA-2 and adjacent exploration areas, Duval County, Texas: SRK Consulting Engineers and Scientists technical report NI 43-101, prepared for Uranium Energy Corp., 106 p., accessed June 22, 2012, at http://www.uraniumenergy.com/_resources/reports/ Palangana_NI_43-101_Technical_Report_199600_010_ KG_012-opt.pdf.

Spiering, E.D., Hillard, P.D., and Inman, J.R., 2009, Exploration and discovery of blind breccia pipes-The potential significance to the uranium endowment of the Arizona strip district, northern Arizona: U2009 Global Uranium Symposium, Keystone, Colorado, May 9-13, 2009, abstracts, p. 17.

Talvivaara Mining Company Plc., 2011, Mineral resources: Talvivarra Mining Company Plc. Web site, accessed June 22, 2012, at http://www.talvivaara.com/operations/ Mineral_resources.

Titley, Malcolm, 2009, The Mutanga project-Located in Southern Province, Republic of Zambia: GSA Global (UK) Ltd. technical report NI 43-101, prepared for Denison Mines Corp., 225 p., accessed June 12, 2012, at http://www.denisonmines.com/content/pdf/ ni43_101_mutanga_uranium_19mar09.pdf.

Toro Energy Ltd., 2011, Projects: Toro Energy Limited Web site, accessed June 12, 2012, at http://www.toroenergy.com.au/ projects.html. 
TradeTech, 2011, TradeTech-Specialists in nuclear fuel markets - Consulting and supply/demand analysis: Tradetech Web site, accessed [date], at http://www.uranium.info/.

U.S. Enrichment Corporation Inc., 2011, Megatons to Megawatts: USEC Inc. Web site, accessed February 2011, at http://www.usec.com/megatonstomegawatts.htm.

Ux Consulting Company LLC, The, 2010, Uranium suppliers annual: The Ux Consulting Company, LLC special report, $500 \mathrm{p}$.

Ux Consulting Company LLC, The, 2011, The industry's leading source of consulting, data services \& publications on the global nuclear fuel cycle markets: The Ux Consulting Company, LLC Web site, accessed January, 2011, at http://www.uxc.com/ index.aspx.

Vance, Robert, 2005, What can forty years of red books tell us?: Organization for Economic Co-operation and Development Publishing, $19 \mathrm{p}$.

Vettraino, Fortunato, 2010, Brief update on the nuclear energy programme in Italy and related uranium supply features: Joint Nuclear Energy Agency/International Atomic Energy Agency Group on Uranium, meeting, 45, Saskatoon, Canada, August 19-20, 2010, presentation, Organisation for Economic Co-operation and Development Nuclear Energy Agency and International Atomic Energy Agency 6 p.
Vettraino, Fortunato, 2011, Updates to the nuclear energy programme in Italy and related uranium outlook: Joint Nuclear Energy Agency/International Atomic Energy Agency Group on Uranium, meeting, 47, Issy Les Moulineaux-Paris, France, November 2-4, 2011, presentation, $7 \mathrm{p}$.

World Nuclear Association, 2009, Projected uranium requirements to 2030: World Nuclear Association Web site, accessed January 2011, at http://www.world-nuclear.org/.

World Nuclear Association, 2011a, The global nuclear fuel market; Supply and demand, 2011 to 2030: World Nuclear Association, $197 \mathrm{p}$.

World Nuclear Association, 2011b, [Home page]: World Nuclear Association Web site, accessed January 2011, at $h t t p: / / w w w . w o r l d$-nuclear.org/.

World Nuclear News, 2007, New study on uranium from phosphates: World Nuclear News, July 31, accessed March, 2011, at http://www.world-nuclear-news.org/ newsarticle.aspx?id $=13796 \&$ LangType $=2057$.

Zhang, Decun, 2010, Uranium resources, production and requirements in China: Joint Nuclear Energy Agency/International Atomic Energy Agency Group on Uranium, meeting, 45, Saskatoon, Canada, August 19-20, 2010, presentation, $8 \mathrm{p}$. 



\section{Appendix 1. Analysis of Operating Mines and Advanced-Stage Uranium Properties, by Country}

This appendix describes uranium RAR and production in the most important countries that contain uranium resources. In addition to uranium that is actively being produced or is in potential near-future production, the country narratives discuss projects that are likely to take longer to develop than those studied for this report. Possible impediments to or potential increases in uranium production are discussed for each major uranium-producing country worldwide.

\section{Argentina}

Argentina reports $10,400 \mathrm{tU}$ mineable in the top two cost categories ( $<$ USD 130/kgU and $<$ USD 260/kgU), and it reports 7,000 tU mineable at less than USD $80 / \mathrm{kgU}$. Argentina mined uranium for use in its domestic reactors until the late 1990s when it suspended domestic mining because less expensive uranium available on the world market became more attractive. In 2006, national policy tasked the

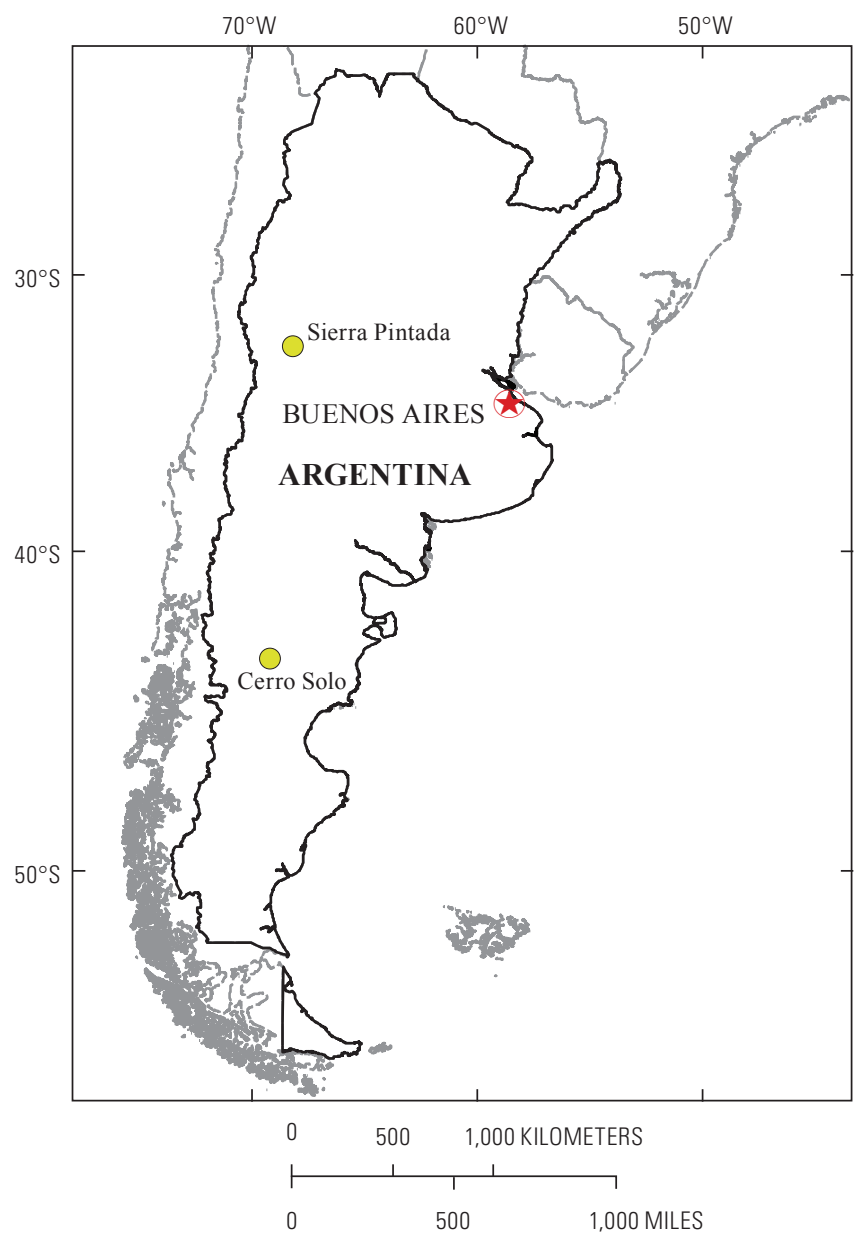

Figure 1-1. Location of uranium mines in Argentina, 2010. From Bianchi (2010).
Comision Nacional de Energia Atomica (CNEA) to restart local production, and government exploration expenditures have increased dramatically (Bianchi, 2010; NEA-IAEA, 2010). Two mines - the Sierra Pintada deposit (2,620 tU), part of the San Rafael Mining and Milling complex, and Cerro Solo (3,900 tU) - are on standby while CNEA evaluates the feasibility of restarting the mining of these deposits (IAEA, 2009; Bianchi, 2010; Ux Consulting Company LLC, 2010) (fig. 1-1). Argentina has also begun a program to assess the country's potential undiscovered resource.

\section{Australia}

The three operating uranium mines in Australia include two of the most prolific world producers during 2009. The large underground Olympic Dam (Roxby Downs) mine, operated by BHP Billiton, produced 2,981 tU, and the openpit Ranger mine operated by Rio Tinto produced 4,423 tU. Heathgate Resources Pty. Ltd (Heathgate) owns and operates the Beverly ISL mine (South Australia), which produced 559 tU (McKay and Carson, 2010) (fig. 1-2).

Olympic Dam is a polymetallic Iron Oxide Copper Gold deposit currently mined primarily for gold and copper, with uranium production (capacity 3,820 tU/yr) incidental to these commodities. The total RAR (295,000 tU) ranks Olympic Dam as the world's largest uranium deposit, holding 34 percent of the world's total identified uranium resource (Mckay and Carson, 2010). Although uranium's economic contribution to the mine's economic viability is significant, its low grade

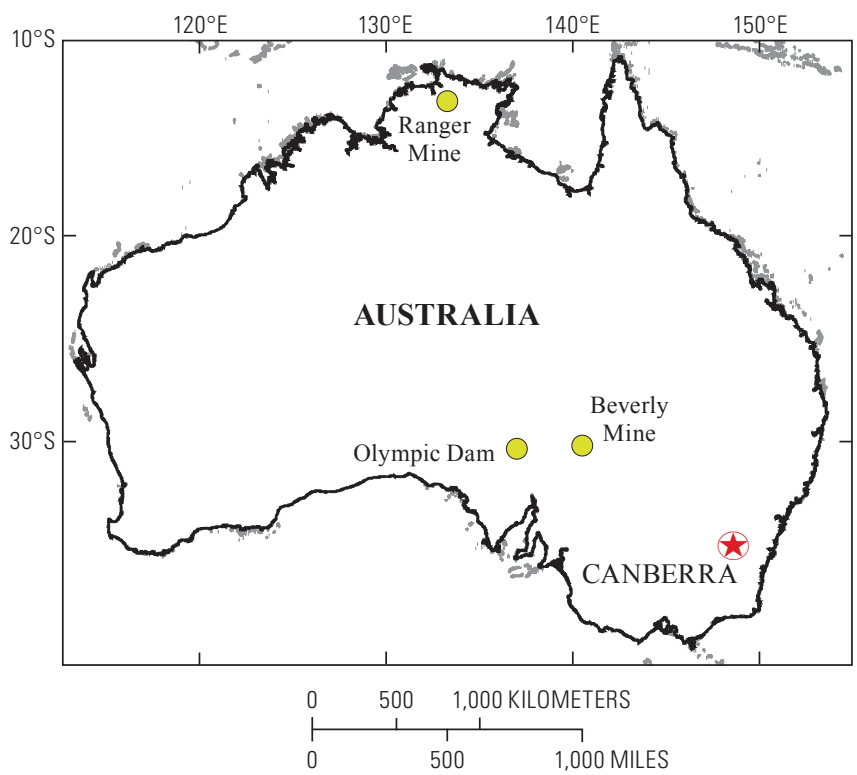

Figure 1-2. Location of operating mines producing uranium in Australia. From Mckay and Carson (2010). 
( 0.023 percent $U$ ) would, at current prices, probably preclude production of uranium alone from this mine. Olympic Dam is, however, the world's fourth largest remaining copper deposit, and the fifth largest gold deposit. The future price of copper and gold will therefore more probably influence uranium production from Olympic Dam. Technical issues have interrupted production of uranium at Olympic Dam in the past. Most recently, production was cut 75 percent during October 2009 through March 2010 because a hoist that transported ore to the surface failed.

A proposed expansion project that will increase the uranium production capacity at Olympic Dam to $16,100 \mathrm{tU}$ is in the permitting process (IAEA, 2009). A feasibility study is complete, and a draft Environmental Impact Statement has received public comment and is in review by the government. This expansion includes the construction of a large openpit mine estimated to eventually be $6 \mathrm{~km}$ by $5 \mathrm{~km}$ and more than 1,200 meters deep, southeast of the current underground mine. The cost of this expansion will range from 30 to 50 billion U.S. dollars. One of the greatest technical challenges for the project is securing adequate water to run the proposed operation. BHP Billiton's preferred solution is to desalinate ocean water at Point Lowly in the Upper Spencer Gulf and pipe the water $320 \mathrm{~km}(200 \mathrm{mi})$ to the mine. While this paper was in review, BHP Billiton announced it would suspend expansion of this pit, pushing production of this uranium to an undetermined time in the future (ABC News, 2012). This supply was projected to have become available in about 2020, and provided significant primary supply to the world market. The impact of the loss or delay of this source on forward supply projections for uranium has not been fully evaluated.

The Ranger openpit mine (28,832 tU reserve) appeared to be reaching the end of its mine life in 2007 when it reported RAR sufficient to continue mining until 2014 (NEA-IAEA, 2008). Additional drilling has since identified $34,000 \mathrm{tU}$ of high-grade RAR below the current openpit operation in this unconformity-type deposit (Mckay and Carson, 2010). A decline is being constructed to explore this new resource. In addition, a heap-leach facility is proposed for extracting a resource of 16,100 tU from low-grade RAR on stockpiles and from those remaining in the mine. The Ranger mine has experienced periodic delays in production for several weeks at a time during the rainy season when ore and treatment plants become inaccessible and facilities for impounding tailings have filled with water. Ranger operates within the Kakadu National Park, a United Nations Educational, Scientific and Cultural Organization World Heritage site. The operations are currently licensed through 2021, and any extension of operations beyond that time period would require new legislation. Production from Ranger has declined since at least 2007, and declines are likely to continue as the operation targets lowergrade ore through its use of surface heap-leaching and from resources lying deeper underground.
Jabiluka, a large unexploited 123,389 tU reserve, abuts the northern edge of the Ranger lease (IAEA, 2010). This property has been dormant since 2005, when its owner, Rio Tinto, reached an agreement with the Mirarr traditional aboriginal people that would require aboriginal approval prior to development. An exploration tunnel was backfilled with waste rock and unprocessed material, and the property was placed on standby. Development of Jabiluka will depend on the ability to overcome significant permitting impediments.

Another area of active mining and ongoing permitting and development are sandstone uranium deposits in the Fromme Embayment in South Australia. The Beverly ISL uranium mine (12,192 tU), owned and operated by Heathgate Resources Pty. Ltd. (Heathgate), is located in the Fromme Embayment, as are the following developing properties: Honeymoon (2,500 $\mathrm{tU})$, owned by Uranium One, Oban (1,781 tU inferred), owned by Curnamona Energy Ltd., and Four Mile (23,462 tU ), owned by Quasar Resources Pty. Ltd., and newly discovered Pepegoona (900 tU), also owned and operated by Heathgate (Mckay and Carson, 2010; Ux Consulting Company LLC, 2010). Protests against ISL mining as a procedure for recovering ores in Australia prompted the Australian government to investigate the impacts of leach mining (Commonwealth of Australia, 2010). The aquifer being mined is highly saline, and the area is remote from cities and farms so impacts on human health, on stock, or on agriculture from mining of uranium from this aquifer were determined to be minimal. Permitting and mining has proceeded fairly rapidly, and it is likely that uranium will continue to be produced from this region in response to ongoing exploration and development.

In Western Australia, BHP Billiton is conducting a feasibility study of its Yeelirrie deposit (44,077 tU inferred). This is a calcrete uranium deposit located 4 to $8 \mathrm{~m}$ below the surface that will be developed by surface operations in a progressive fashion with ongoing reclamation and remediation. Processing details have not yet been reported. This deposit is projected as producing between 2,000 and 2,500 tU per year over a mine life of 20 to 40 years. Two other calcrete uranium deposits in Western Australia are in the prefeasibility stage: the Wiluna project $(9,385 \mathrm{tU})$ being explored by Toro Energy Ltd. and the Lake Maitland resource (10,000 tU), owned by Redport Ltd. (Mckay and Carson, 2010).

\section{Brazil}

Brazil's single operating uranium mine, the Lagoa Real-Caetite mine, a metasomatite deposit, produced $347 \mathrm{tU}$ in 2009 from a remaining reserve of 12,700 tU (fig. 1-3; NEA-IAEA, 2010; Ux Consulting Company LLC, 2010)). An expansion is underway that will double production capacity by 2012 . However, production is expected to fall significantly in the near future, due to licensing delays at a tailings dam (daSilva, 2010). 


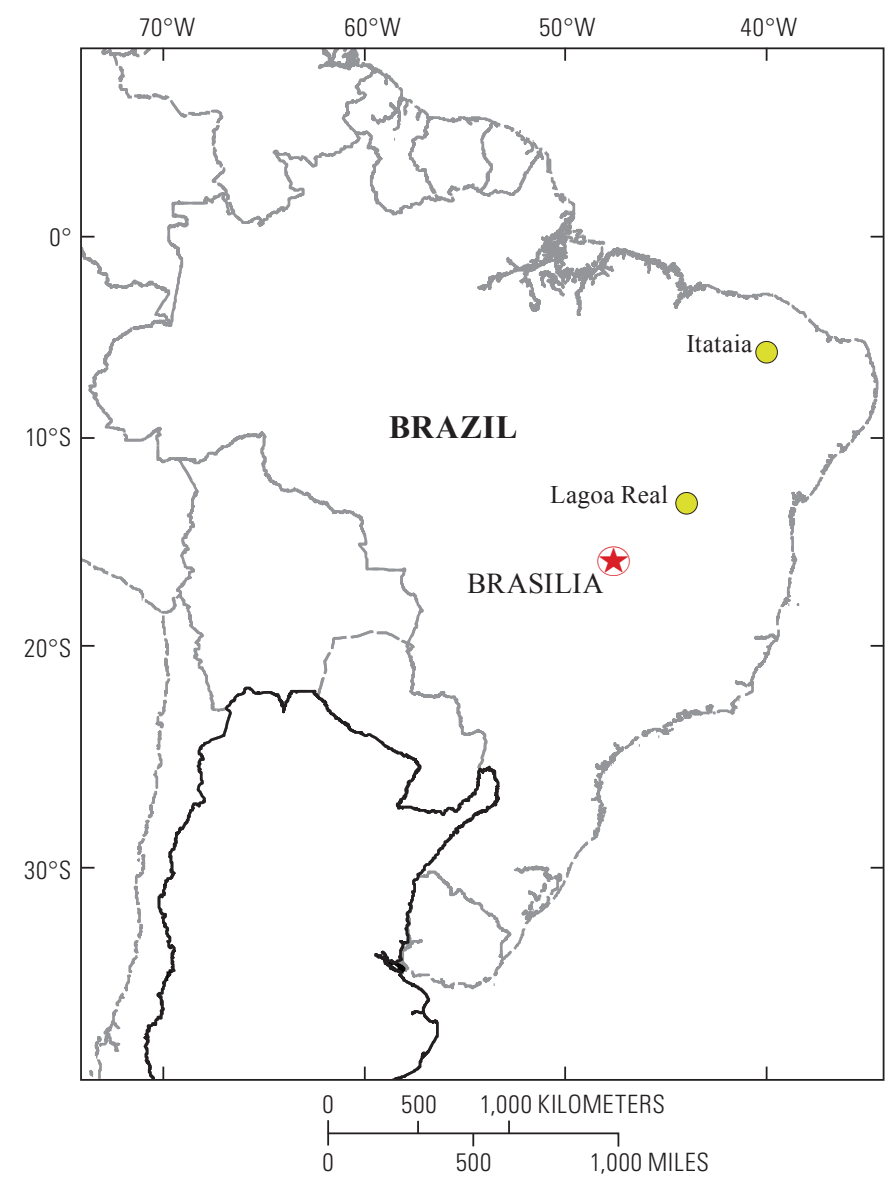

Figure 1-3. Active and developing uranium mines in Brazil. From Dahlkamp (2010).

A pilot plant to produce uranium from the Santa Quitéria/ Itataia phosphate deposit is being designed, constructed, and to be operational by 2012, with a capacity of $1,000 \mathrm{tU} / \mathrm{yr}$. This resource is a substantial 67,240 tU (Ux Consulting Company LLC, 2010). As with all phosphate-uranium deposits, economic development depends on using an appropriate extraction technology, but none has been identified to date. Little exploration is being carried out in Brazil, although favorable geologic conditions exist (Dahlkamp, 2010). All uranium deposits in Brazil are controlled by the government owned Industrias Nucleares do Brazil.

\section{Canada}

Canada's three operating uranium mines produced $10,174 \mathrm{tU}$ in 2009, providing 20 percent of the world's mined uranium (World Nuclear Association, 2011b). Production was from the rich unconformity-related uranium deposits in the Athabasca Basin of northern Saskatchewan. In 2009, the McArthur River mine produced $7400 \mathrm{tU}$, with a large remaining resource of 128,900 tU; McClean Lake produced 1,410 tU, with a small remaining resource of 1,031 tU; and Rabbit Lake produced $1,400 \mathrm{tU}$, also with a relatively small remaining resource of 8,200 tU (fig. 1-4: (Ux Consulting Company LLC, 2010; World Nuclear Association, 2011b).

Deposits in the Athabasca basin that are in the development or feasibility stages include (1) Cameco's Cigar Lake mine, containing a significant reserve of $80,500 \mathrm{tU}$ that is expected to produce in 2012 at an annual capacity of 6,294 tU; and (2) Areva's Midwest deposit, containing RAR of 16,340 tU with a planned capacity of 2,300 tU/yr (Calvert, 2010; Ux Consulting Company LLC, 2010). Cigar Lake, containing 80,500 tU in RAR was expected to be a significant uranium supplier by 2009 , but a series of technical challenges that resulted in mine flooding and a total mine shutdown have delayed production until at least 2012. Water inflow is a significant problem in this wet northern environment, and the construction of freeze walls to control this water flow in active underground mines continues to be a technical and economic challenge. Midwest was originally planned as an underground mine, with startup in 2011, but an openpit option with no planned startup date is now reported (Calvert, 2010). Other advanced-stage projects in the Athabasca basin include Areva's Kiggavik (51,574 tU) and Cameco's Millennium $(18,002 \mathrm{tU})$ deposits. Outside the Athabasca basin, Strateco Resources Inc. is exploring the 7,770-tU Matoush deposit in Quebec by surface drilling and construction of an underground exploration ramp scheduled for 2012. Aurora Energy Resources Inc., a subsidiary of Paladin, is working to develop two deposits in Labrador: the Jacques Lake $(4,000 \mathrm{tU})$ and the Michelin $(25,923 \mathrm{tU})$ deposits.

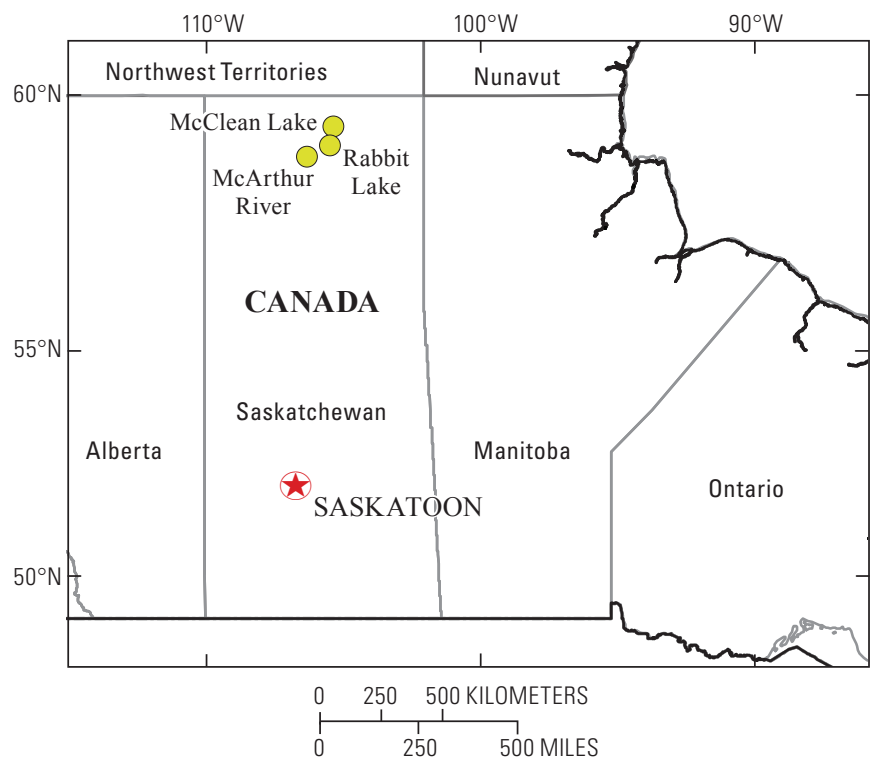

Figure 1-4. Active uranium mines in Canada. From WNA (2011). 


\section{Central African Republic}

In 2010, a feasibility study of Areva's Bakouma deposit containing 9,885 tU was being conducted, with tentative plans to develop the mine by 2015 (fig. 1-5). In late 2011, however, Areva suspended the project for two years, stating that the mine was unprofitable at present uranium prices (Ngoupana and others, 2011). The Central African Republic retains a 10-percent interest in Bakouma (Areva NC, 2011).

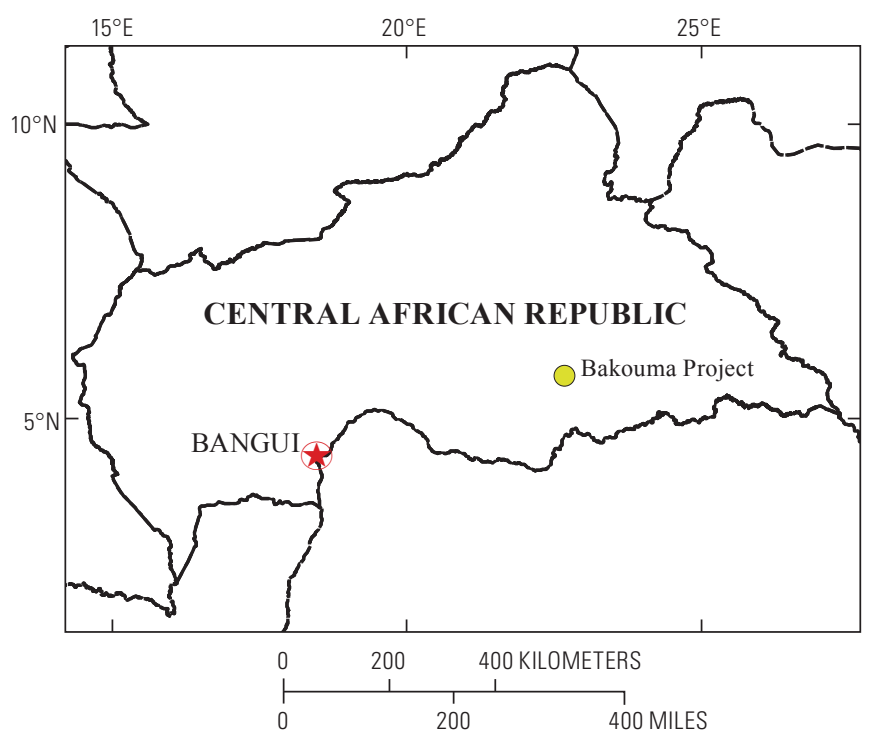

Figure 1-5. Location of the Bakouma deposit, Central African Republic. From Areva NC (2011).

\section{China}

All uranium mines in China are owned and operated by the China National Nuclear Corporation (CNNC). CNNC is a state-owned enterprise with hundreds of subsidiaries, and it fully controls the nation's nuclear fuel cycle of mining, conversion, enrichment, and fabrication. The "Red Books" for 2005, 2007, and 2009 (NEA-IAEA, 2006, 2008, 2010, Dahlkamp (2010) and Zhang, 2010 are this report's sources for resource and production data. Because of the limited reporting from China, there is some confusion about resource and development time lines.

Six production centers are reported for China: Fuzhou (Jiangxi Province), Chongyi (Giangxi Province), Yining (Xinjiang Province), Lantian (Shaanxi Province), Benxi/ Quinglong (Liaoning Province), and Shaoguan (Guandong Province) (fig. 1-6, table 1-1) (NEA-IAEA, 2010). Mines associated with the production centers are reported for the Yining ISL facility (Dep. 512); Lantian (Lantian deposit), Benxi (Benxi deposit), and Quinglong (Quinglong District). Uranium began to be produced from the Quinglong deposit in Liaoning Province through underground mining and surface heap-leaching in 2007. Although the production capacity is listed as $100 \mathrm{tU} / \mathrm{yr}$, Quinglong has not achieved full capacity because of lower than expected yields from heap-leaching. Production capacity and RAR are listed in table 3.

Mines reported as operating but with no associated production center include Xiangshan, Jiangxi Province; Xiazhuang, Guangdong Province ; Yili, Xinjiang province; Tengchong, Yunnan Province; Lianshanguan, Liaoning Province; Ziyauan, Guangxi Region; and Tengchong, Yunnan Province. Because Tengchong is listed as an ISL mine, production does not require a mill, and so no production center is associated with it (table 1-1).

Combining information reported in the 2009 "Red Book," in Dahlkamp (2010), and in the Uranium Suppliers Annual (Ux Consulting Company LLC, 2010), this report proposes the following associations of mine and mill, as based on the proximity of a production district where mines are listed as

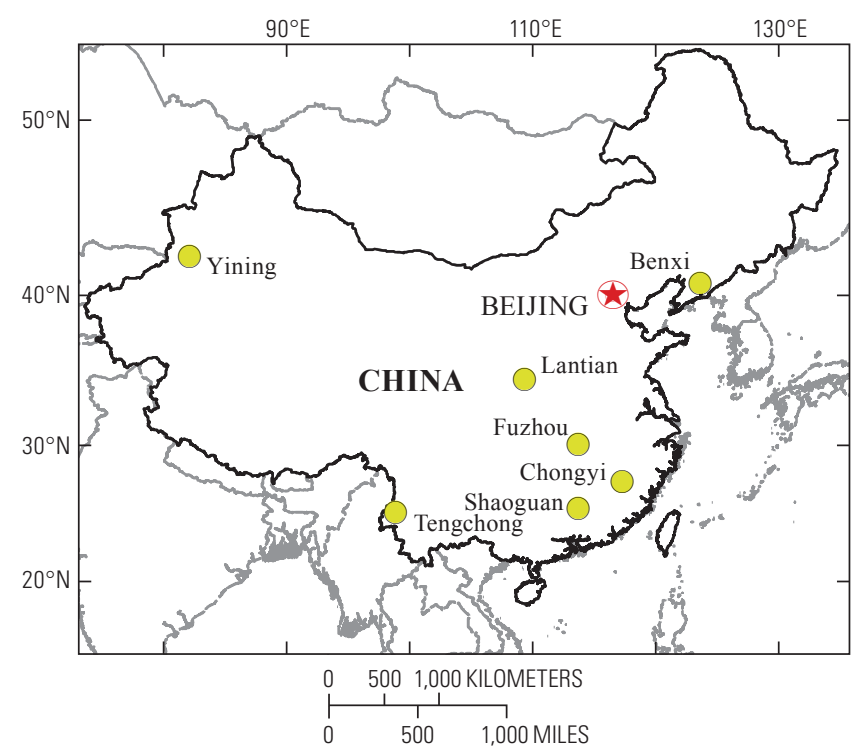

Figure 1-6. Major uranium production centers in China. From Dahlkamp (2010).

Table 1-1 Chinese uranium mines and associated production centers inferred for these mines.

\begin{tabular}{|c|c|c|}
\hline \multicolumn{3}{|c|}{ Operating Uranium Mines and Production Centers in China } \\
\hline $\begin{array}{l}\text { Production } \\
\text { center }\end{array}$ & $\begin{array}{c}\text { Reported } \\
\text { associated mine }\end{array}$ & $\begin{array}{c}\text { Inferred } \\
\text { associated mine }\end{array}$ \\
\hline Fuzhou & & Xiangshan \\
\hline Chongyi & & \\
\hline Yining & Dep.512 & Yili \\
\hline Lantian & Lantian & \\
\hline Benxi/Benxi & Benxi & Lianshanguan \\
\hline Benxi/Qinglong & Qinglong & \\
\hline Shaoguan & & Xiazhuang \\
\hline \multicolumn{3}{|c|}{ Operating mines with no associated production center } \\
\hline $\begin{array}{l}\text { Tengchong } \\
\text { Zivauan }\end{array}$ & (ISL-No milling $\mathrm{r}$ & ed for production) \\
\hline
\end{tabular}


operating: (1) the Fuzhou mill, which may be processing ore from deposits in the Xiangshan district; (2) the Yining mill, which may be processing ore from the Yili district; (3) the Shaooguan, milling ore from the Xiazhuang deposit; and (4) the Benxi, milling ore from the Lianshanguan deposit. This leaves the Ziyuan deposit for which no production center can be surmised.

Several deposits in China are described as being in some stage of feasibility. The 3,000-tU Sihongtan deposit near the Yining production area is an ISL deposit undergoing pilot testing. The 5,000-tU Dongsheng deposit in Inner Mongolia was determined not to be amenable to ISL mining, but feasibility studies of mining this resource using underground methods are being conducted. Feasibility studies are also reported at the 19,400-tU Erlian, the 17,000-tU Zaohuohao, and the 21,600-tU Erdos deposits in Inner Mongolia. The 5,000-tU Guyuan deposit in Hebei Province is in pilot testing or in construction. The Liaohe deposit of unknown size is also in the feasibility stage, according to the 2009 "Red Book". The 9,000-tU Turp-Hame deposit, possibly in the Turpan-Hami Basin that also hosts the Sihongtan deposit, is listed as an ISL project in the planning stages. The Shihongtan deposit in the Inrpan-Hami Basin in Xingiang Autonomour region is listed as in the feasibility stage in the IAEA Uranium Deposits database (IAEA, 2010), although the 2009 "Red Book" did not report this resource.

The 2009 "Red Book" reported that China has $171,400 \mathrm{tU}$ in RAR from 13 deposits. Some of these deposits were described separately as operating mines, some as a depleted deposit, and some as being dormant; the status of several others is unknown. An additional "statistical" 1.2 to 1.7 million tonnes of "potential uranium resources are predicted" (NEA-IAEA, 2010). The status of many of these deposits is unknown; one is listed in the IAEA uranium deposits database as depleted (IAEA, 2010). Tables 2 and 3 list deposits believed to be operating or to be in some stage of feasibility. As a geologically diverse region, China might be expected to have a larger uranium resource than has been reported to date. The low numbers reported here for these resources may reflect lack of exploration, incomplete reporting, or the absence of a uranium-rich province within the country.

In addition to domestic resources, $\mathrm{CNNC}$ has an interest in RAR from the Azelik deposit in Niger; from the Gurvanbulag deposit in Mongolia; and from the Zhalpak, Irkol, and Semisbai deposits in Kazakhstan. The production and RAR for these deposits are described in this appendix under their respective countries.

\section{Czech Republic}

The Czech Republic has two operating uranium mines: the Straz mine in the Straz pod Ralskem district in northern Czech Republic, and the Rozna mine, part of the Rozna-Olsi

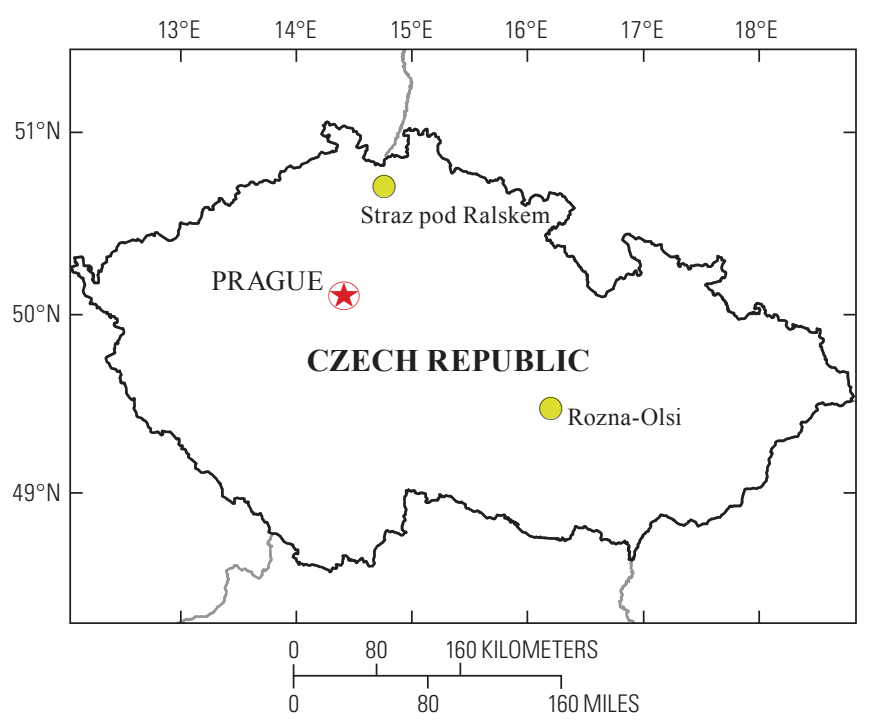

Figure 1-7. Uranium production centers in the Czech Republic. From OECD/NEA-IAEA (2010).

uranium field (fig. 1-7). Remaining RAR at Rozna are $680 \mathrm{tU}$, and at Straz they are 1,320 tU (NEA-IAEA, 2010). All uranium-related activities, including mining and environmental restoration, are carried out by the DIAMO state enterprise (DIAMO s.p.).

At Rozna, production using underground methods during 2009 was projected to be $255 \mathrm{tU}$. Mining is expected to continue through 2012 and beyond if it remains profitable. Production at Straz is a byproduct of remediation of this former ISL facility. In 2009, Straz produced $38 \mathrm{tU}$ (100,000 pounds. $\mathrm{U}_{3} \mathrm{O}_{8}$ ) and production is decreasing as environmental cleanup at the mine site continues while uranium concentrations in leachate solutions decrease. At Straz more than 4.5 million tonnes of sulfuric, nitric, hydrochloric, and hydrofluoric acid were used to mine this deposit during the 30 -year period 1967-1996. Cross-contamination between aquifers allowed mining solutions to migrate into the drinking-water aquifer that the local community relied on. In 2009, the Czech Ministry of Economics proposed that mining be resumed at Straz either by underground or ISL techniques.

Government policy set in 1980 in the Czech Republic was to eventually close all of the nation's uranium mines, and for this reason no new mines are anticipated to open in the near future. However, uranium resources are believed to exist in several regions. Of the 23 identified Czech Republic deposits, 20 have been mined, Rozna is currently being mined, and the remaining two identified deposits, Osecna-Kotel and Brzkov, remain unexploited. In 2008 , the Australian mining company, Uran Ltd. (Uran), applied for a lease to initiate exploration around the 7,500-tU Brzkov deposit in the central Czech Republic, but the Environment Ministry did not grant the license. Uran also attempted to recover uranium from surface-dump rock at the Pribram mine, but whether this venture was successful is unknown. 


\section{Denmark (Greenland)}

The multielement Kvanefjeld deposit (Greenland Minerals and Energy Ltd.) contains an identified 85,614 tU, as well as rare-earth elements and zinc in mineable quantities (fig. 1-8: (NEA-IAEA, 2010). Several other exploration targets and prospective terrane exist throughout the country. Currently, Denmark has banned uranium exploration and exploitation in Greenland. Although a feasibility study has been performed on the Kvanefjeld deposit, the in-place ban on mining prevents this report from including Kvanefjeld among world uranium resources.

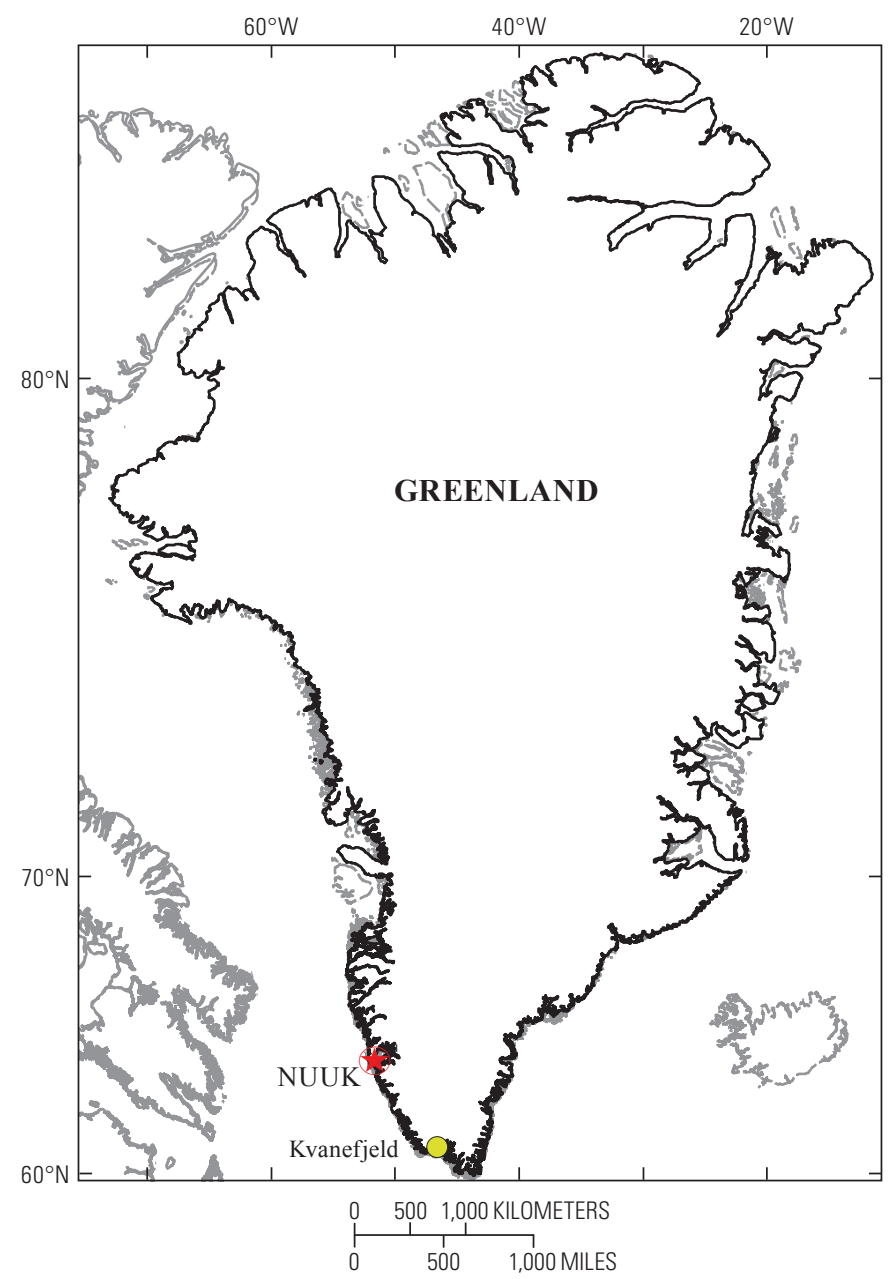

Figure 1-8. Location and geology of the Kvanefjeld deposit, Greenland. From Greenland Minerals and Energy Ltd. (2011).

\section{Finland}

Although there is considerable exploration for uranium in Finland, there is no current production. The Talvivaara polymetallic black shale deposit, in the Kainuu Province of eastern Finland is mined for nickel and zinc that contain trace uranium (0.001 to 0.004 percent U) (fig. 1-9). The mine operator, Talvivaara Mining Company $\mathrm{Plc}$, is constructing a uranium extraction circuit at the mine that is expected to be complete in 2012. Cameco has signed an agreement to help finance production and to buy this uranium, which is estimated to be produced at a rate of $350 \mathrm{tU} / \mathrm{yr}$.

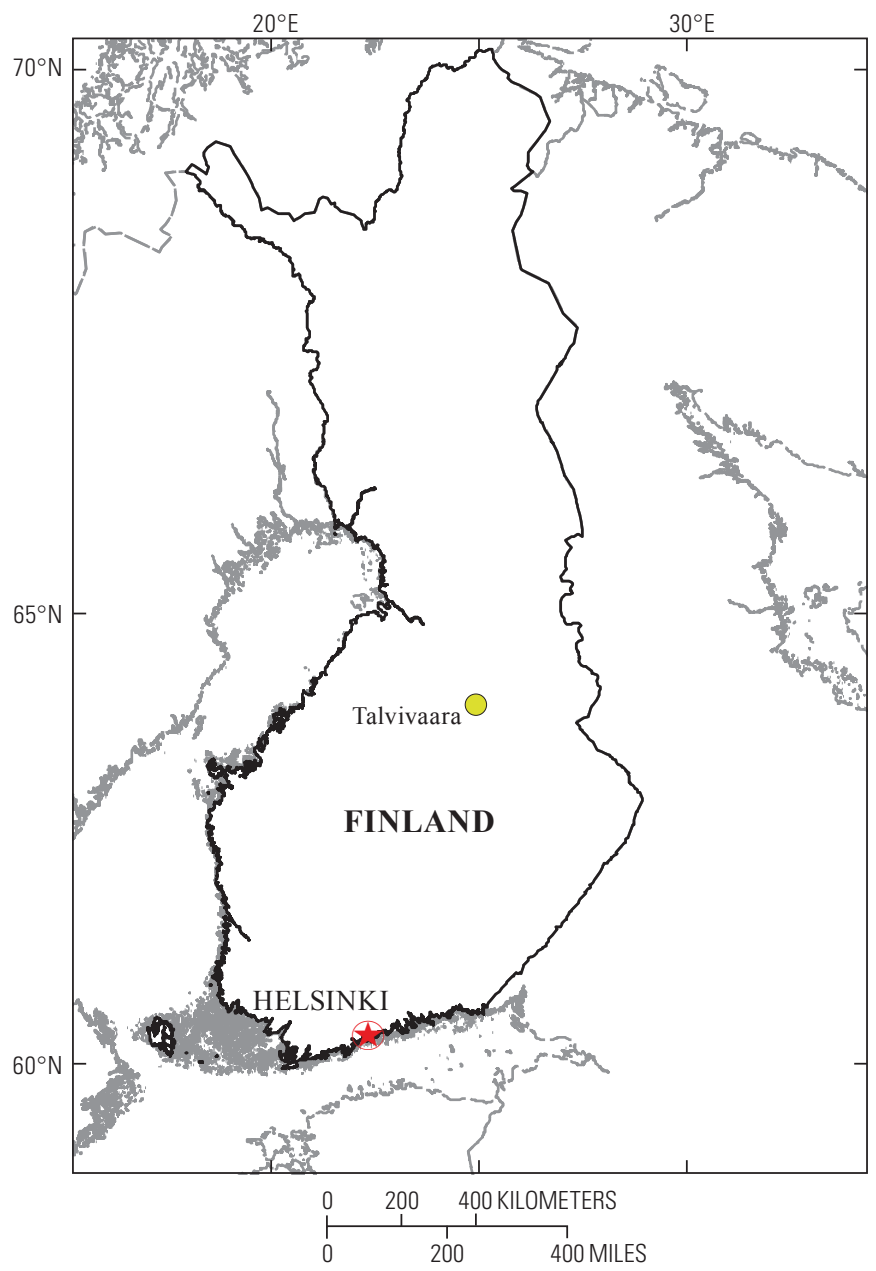

Figure 1-9. Location of the Talvivaara uranium deposit in Finland. From Talvivaara Mining Company Plc., (2011). 


\section{India}

All uranium mines and production are owned and controlled by Uranium Corporation of India, the India State mining company. Six operating mines are reported: Narwapahar (11,500 tU); Jaduguda (8,400 tU); Turamdih and Banduhurang (3,750 tU); Bagjata (2,106 tU); and Bhatin (2,200 tU) mines (Chaki, 2010; IAEA, 2010) (fig. 1-10). Since India does not regularly report RAR remaining in these mines, the available resource figures probably do not account for depletion by mining and should be considered high. Three mines are in development: the Mohuldih (unknown resource), LambapurPeddagattu (unknown resource) and the Tummalapalle (12,555 tU) deposits. The RAR estimated to be remaining in operating and developing mines in India total 40,511 tU. The 2009 "Red Book" reports a slightly larger number $(55,200 \mathrm{tU})$ for the country, but it does not allocate quantities to individual mines. Other mine development reported for India is still in the planning stages, and is not included in this summary. Uranium has been recovered from the Rakha and Mosaboni mines as a product of copper mining, but it is not currently being produced from these mines (Ux Consulting Company LLC, 2010).

Because India has historically been unable to import uranium, the Uranium Corporation of India has explored and continues to aggressively explore prospective terrane in order to provide fuel to its 19 operating powerplants. India is also actively exploring the viability of thorium-fueled rather than uranium-fueled reactors because the country has a significant thorium resource. It does not seem likely that India will supply uranium to the world market in the immediate future.

\section{Iran}

Exploration and development in Iran is performed by the government agency, Atomic Energy Organization of Iran, which reports one existing and one committed production center (NEA-IAEA, 2010). Production capacity is $21 \mathrm{tU}$ from a 100-tU reserve at the Gachin mine, although since at least 2007 this reserve has been reported with no measurable reduction from having been mined (fig. 1-11). The small size and low grade of Gachin ore would probably make this deposit subeconomic without Iran's strong desire for a domestic source for uranium. Development of an underground (90 percent) and openpit (10 percent) mine to exploit the $900-\mathrm{tU}$ Saghand deposit is underway, with production at a rate of $50 \mathrm{tU}$ per year planned to commence in 2012. The 2009 "Red Book" reports a strong exploration program, utilizing modern techniques and targeting several different geologic provinces and deposit types. It is not anticipated than Iran will contribute uranium to the world market in the near future because mined uranium will be used domestically.

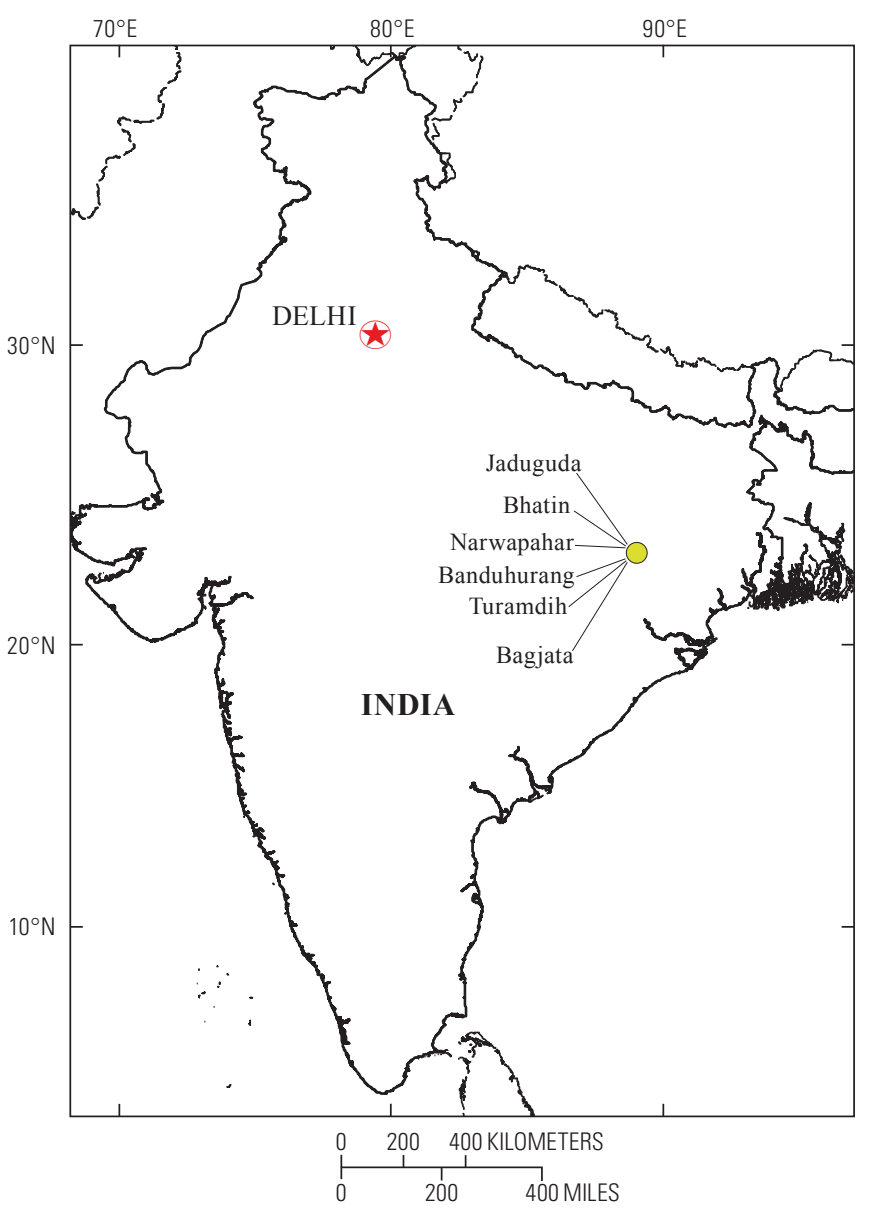

Figure 1-10. Location of current production centers and prospective areas of India. From Chaki (2010).

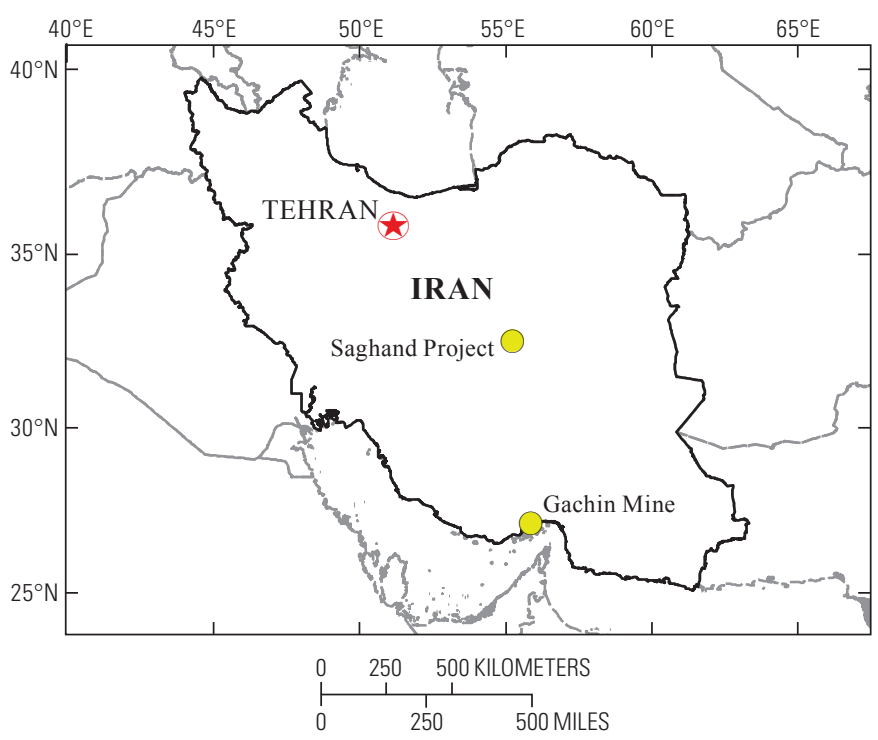

Figure 1-11. Location of the Gachin mine and the Saghand uranium deposit, Iran. From Dahlkamp (2010). 


\section{Jordan}

Jordan does not currently produce uranium, and has no deposits that can be classified as imminent producers. However, a number of uranium companies, including France's Areva and Australia's Rio Tinto, are actively exploring in this country. As well, the Jordan Atomic Energy Commission's commercial arm Jordan Energy Resources Inc. (JERI) is conducting regional exploration to encourage commercial development of uranium deposits in the country. A total resource of between 59,360 and 165,470 tU is identified in phosphate deposits in Jordan. In addition, surficial deposits ranging from 50,000 to 70,000 tU in are currently being explored in central Jordan south of Amman by JERI (NEA-IAEA, 2008; IAEA, 2010; Ux Consulting Company LLC, 2010).

\section{Kazakhstan}

The national mining company, KazAtomProm, is responsible for all uranium mining activities in Kazakhstan, the world's largest uranium producer. KazAtomProm has formed joint-venture partnerships with the following mining companies to develop properties: Areva, Cameco, Uranium One, Sumitomo Corporation, Energy Asia Ltd., and CNNC.

Fifteen operating mines and two pilot projects were reported for Kazakhstan in 2010 (tables 3, 4). The mines are located in three mining districts: (1) the two pilot projects in Kokshetau Region (Tselinny, and Semisbai); (2) the 12 mines in the Chu-Sarysu district (Akdala, Centralnoye, Chiili, Stepnoye, Inkai, S. Inkai, Muyunkum/Tortkuduk, Zarechnoye, Central Mynkuduk, W. Cynkuduk, Budenovskoye 2, and Budenovskoye 1,3,4); and (3) the three mines in the Syr-Darya district (Kharasan 1, Kharasan 2, Irkol) (NEA-IAEA, 2010) (fig. 1-12). ISL mining using an aggressive sulfuric acid lixiviant is the most common mining method in the primarily sandstone-hosted roll-front deposits. Production costs are low, permitting and restoration hurdles are not high, and the country is aggressively promoting the development of deposits, the result being that uranium production is expanding rapidly. With a large national resource of 459,677 tU, Kazakhstan is expected to continue as a top producer for the immediate future.

\section{Malawi}

Malawi reports one operating uranium mine, the Kayelekera deposit that is being mined using openpit methods by Paladin (fig. 1-13). Paladin is producing 1,270 tU/yr from the 11,265-tU deposit, which it expects to deplete by 2020 (Paladin Energy Ltd., 2011).

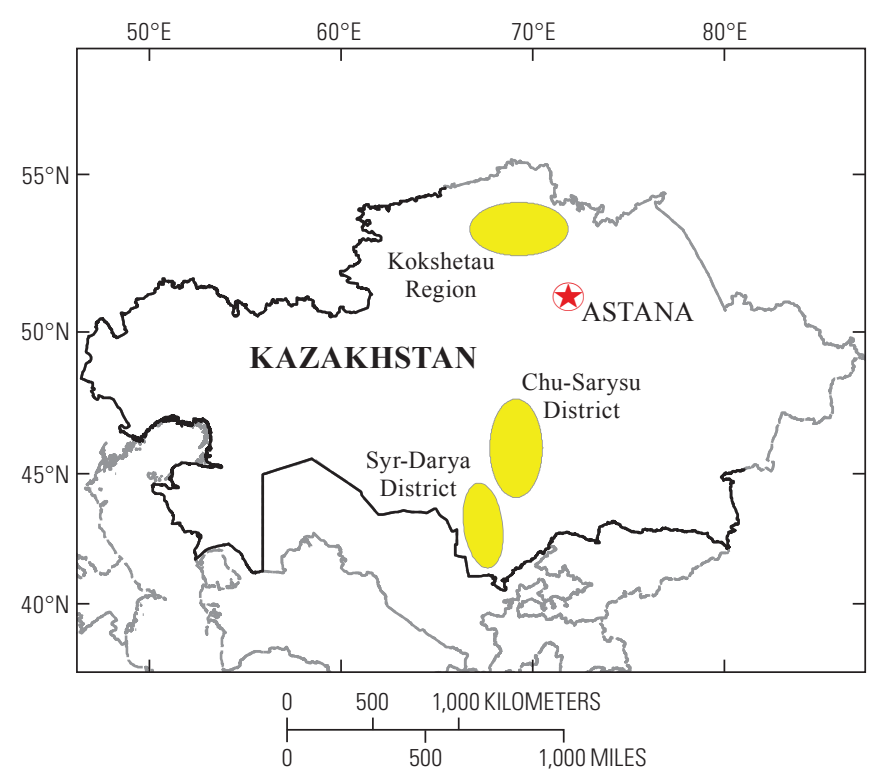

Figure 1-12. Location of major uranium mining districts and operating mines of Kazakhstan. From Dahlkamp (2010).

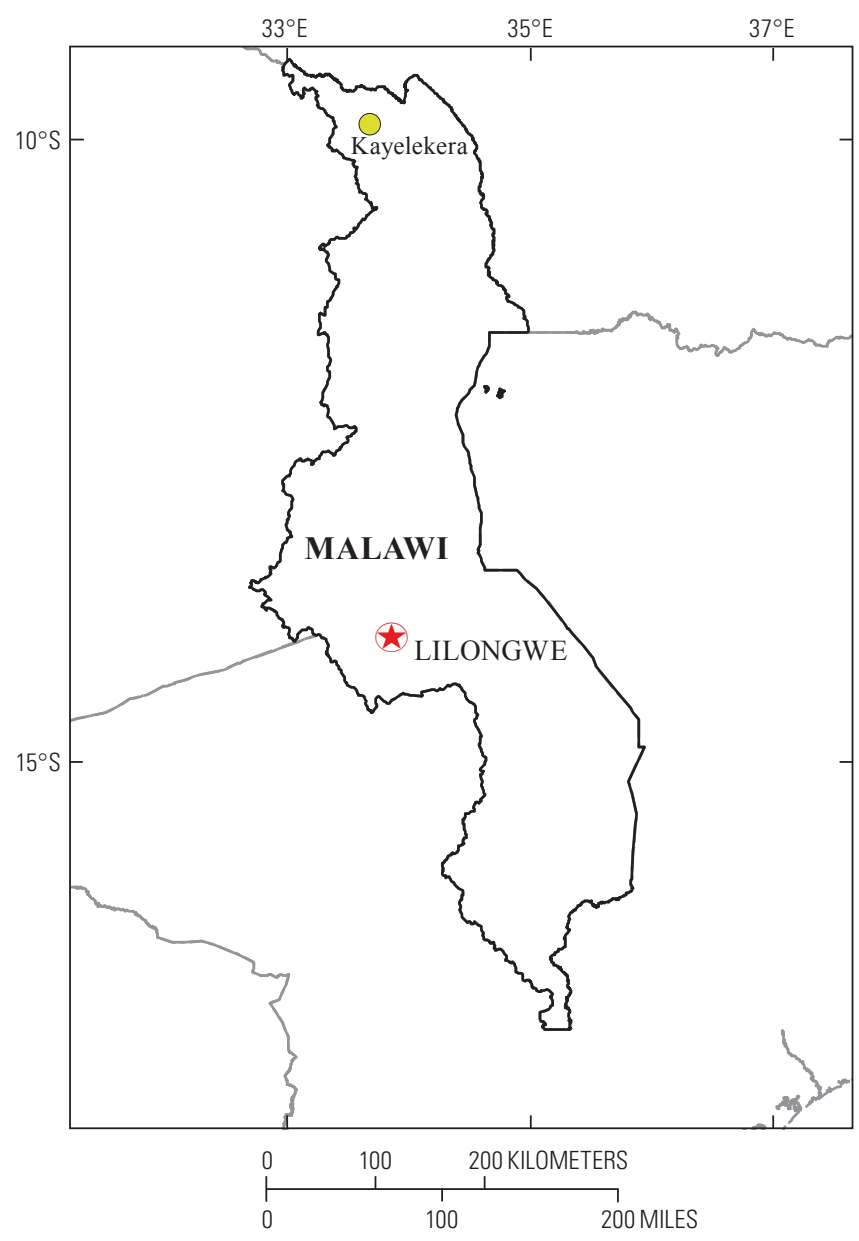

Figure 1-13. Location of the Kayelekera Mine in Malawi. From Paladin Energy, Ltd. (2011). 


\section{Mongolia}

One advanced-staged project is reported for Mongolia, the Dornod deposit containing 24,780 tU, which is expected to be mined by Khan Resources Inc. at a rate of 1,159 tU/yr during the 10 years beginning about 2015 (fig. 1-14) (NEA-IAEA, 2010). The deposit was partly mined by the Russian Federations' Priargunsky Mining and Chemical Enterprise during 1988-1995, when infrastructure, including a rail line over which ore was shipped $500 \mathrm{~km}$ to Krasnokamensk in Siberia, was developed at the mine site. The Nuclear Agency of Mongolia delayed development of the Dornod deposit by invalidating Khan's mining license in 2009 (Khan Resources Inc., 2011). Litigation ensued, and has not been fully resolved. Uranium may be produced from Mongolia from this deposit in the near future if title issues for Dornod are successfully resolved so that Khan can begin raising sufficient financing for the project.

Four mining companies are involved in uranium exploration throughout Mongolia: Cameco, East Asia Minerals Corp., Areva, and Solomon Resources Ltd. No other projects are far enough advanced to anticipate production in the near future.

\section{Namibia}

Following the passage of the Minerals Act of 1992 that established uranium as a strategic mineral, the government of Namibia began working to develop mining guidelines for studying the cumulative societal and environmental impacts of mining in the west-central Erongo region, the major uranium province of Namibia. Overwhelmed with applications while working to develop a national policy for uranium mining, Namibia in 2007 called a moratorium on granting new exploration licenses.

Two mines are producing uranium in Namibia; Rio Tinto's Rossing Mine (50,657 tU resource) with a production capacity of 3,817 tU/yr; and Paladin's Langer Heinrich mine, with a production capacity of $1,425 \mathrm{tU} / \mathrm{yr}$ from a $60,830 \mathrm{tU}$ reserve (fig. 1-15) (NEA-IAEA, 2010; Ux Consulting Company LLC, 2010). Rossing has been in operation since 1976, and has a lifeof-mine operating plan that details production through 2023 . If mine-site exploration results are encouraging, mine life may be extended. Rossing is testing enhanced heap-leach techniques that may increase production. At Langer Heinrich, Paladin is capitalizing on recent increases in RAR and is planning a plant expansion that would increase production to 3,500 tU/yr.

Areva is developing the Trekkopje deposit, with tentative plans to begin production from a 42,243-tU reserve at an initial rate of 1,600 tU/yr by 2013, eventually ramping up to $3,500 \mathrm{tU} / \mathrm{yr}$. A mine license was granted in 2008, and pilot testing is underway. The mine life of Trekkopje is expected to be 12 years, until 2023. Also close to production is the 23,269-tU Valencia deposit, which Forsys Metals Corp. is developing with plans to produce $1,000 \mathrm{tU} / \mathrm{yr}$ by 2013 . The

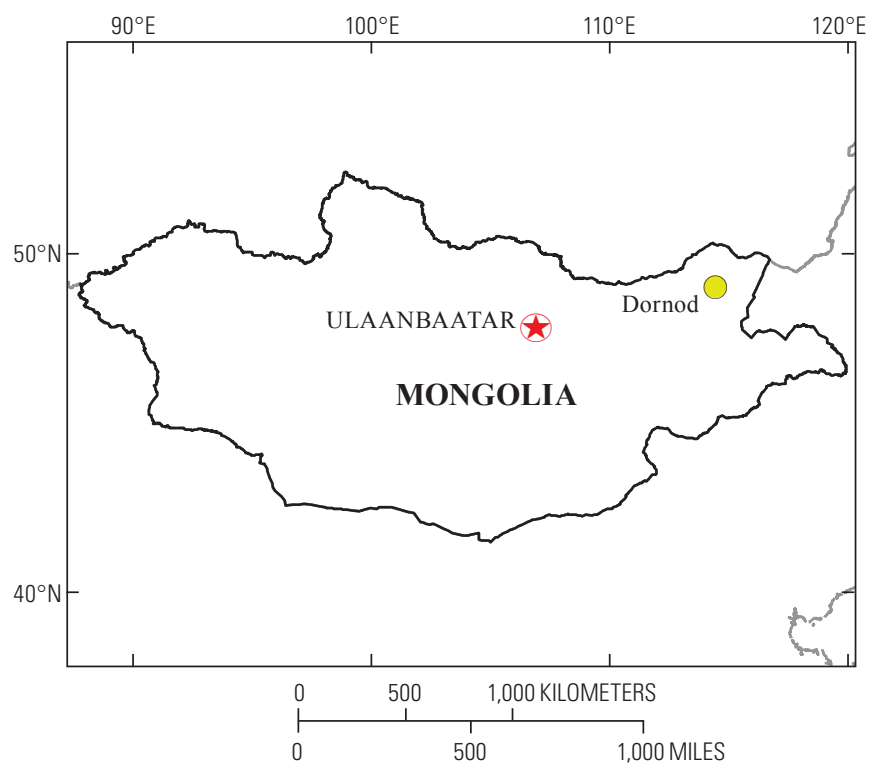

Figure 1-14. Location of the Dornod Uranium Project, Mongolia. From Khan Resources Inc. (2011).

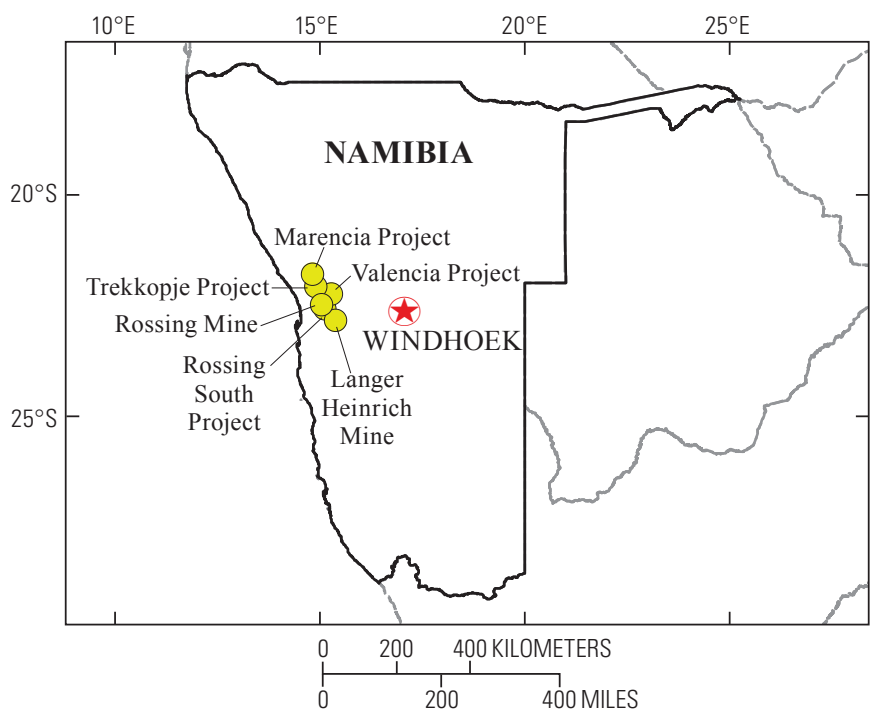

Figure 1-15. Approximate location of operating uranium mines and advanced-stage projects in Namibia. From OECD/NEA-IAEA (2010) and from Marencia Energy Limited (2011).

Marencia uranium deposit $(62,856 \mathrm{tU})$ is being developed to produce at a rate of 1,000 tU/yr by Marencia Energy Ltd. by 2014, with financing through China's Hanlong Energy Ltd. (Ux Consulting Company LLC, 2010). The Rossing South deposit, currently owned by Extract Resources Inc. and part of the larger Husab deposit, contains an estimated 98,846 tU. The Husab deposit is a significant future producer, but was not included in this analysis because it is still in the exploration stage (Ux Consulting Company LLC, 2010). Other projects in Namibia are progressing but are still many years away from production (Itamba, 2011). 


\section{Niger}

Two producing centers, both operated by Areva, are reported for Niger. The 24,670-tU Akouta mine with a production capacity of 2,000 tU/yr, and the 23,171-tU Arlit mine with a production capacity of 2,000 tU/yr (fig. 1-16: (NEA-IAEA, 2010; Ux Consulting Company LLC, 2010).

The Imouraren and Azelik advanced-stage projects are projected to start up by 2013. Areva Company's Imouraren mine has a reserve of $183,520 \mathrm{tU}$, the second largest reserve in the world, and its production capacity is proposed as ranging from 2,000 to 7,000 tU/yr (table 3) (NEA-IAEA, 2010; Ux Consulting Company LLC, 2010). The Imouraren mine is expected to produce uranium for 35 years, through 2048. The Azelik deposit, with 10,800 tU, is jointly being developed to its proposed capacity of $1000 \mathrm{tU} / \mathrm{yr}$ by the Nigerian government and a private Nigerian group, Trendfield Holdings SA (NEA-IAEA, 2010; Ux Consulting Company LLC, 2010). Other mining companies are actively exploring tenements in Niger, but none has reported reaching the feasibility or development stage.

\section{Pakistan}

The Pakistan Atomic Energy Commission (PAEC) controls all uranium mining within the country. Pakistan is nearing the end of a 5-year (2006-2011) exploration program designed to identify domestic uranium supplies nationwide. No recent country reports are available for Pakistan, so estimates of national RAR are based on the IAEA world distribution of uranium deposits database (UDEPO) and on Ux Consulting Company's Uranium Suppliers Annual (IAEA, 2010; Ux Consulting Company LLC, 2010).

Three mines are reported to be operating in Pakistan: the Quabul Khel/Issa Khel, the Tumman Leghari, and the Dera Ghazi Khan mines (fig. 1-17). The Tumman Leghari mine could not be located, but is reported to be in the South Punjab Province. RAR for these deposits are unknown. There is some confusion in the literature about the location of the Quabul Khel and Issa Khel mine/production center (Dahlkamp, 2010; Ux Consulting Company LLC, 2010). It is likely mining is being carried out at Quabul Khel, with the ore being processed at Issa Khel, so the location of both are show on figure 1-17. The cumulative nominal production capacity of Pakistani mines is estimated to be $84 \mathrm{tU}$. One deposit, the Shanawah ISL mine, is in development and is expected to be producing at a rate of $50 \mathrm{tU}$ by 2014 from a resource of 2,578 tU (IAEA, 2010). PAEC claims to have located one thousand favorable uranium areas in the country.

\section{Romania}

The Romanian government's Uranium National Company (UNC) owns and manages exploration, mining, and production of uranium resources. Uranium production in Romania has

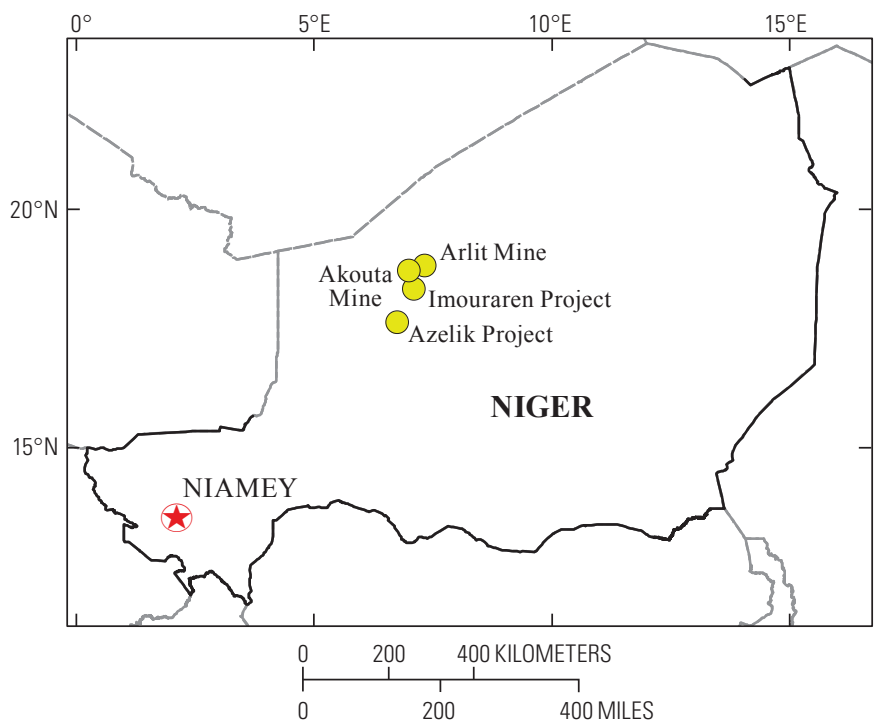

Figure 1-16. Location of uranium mines and advanced stage projects in Niger. From OECD/NEA-IAEA (2010) and Areva NC (2011).

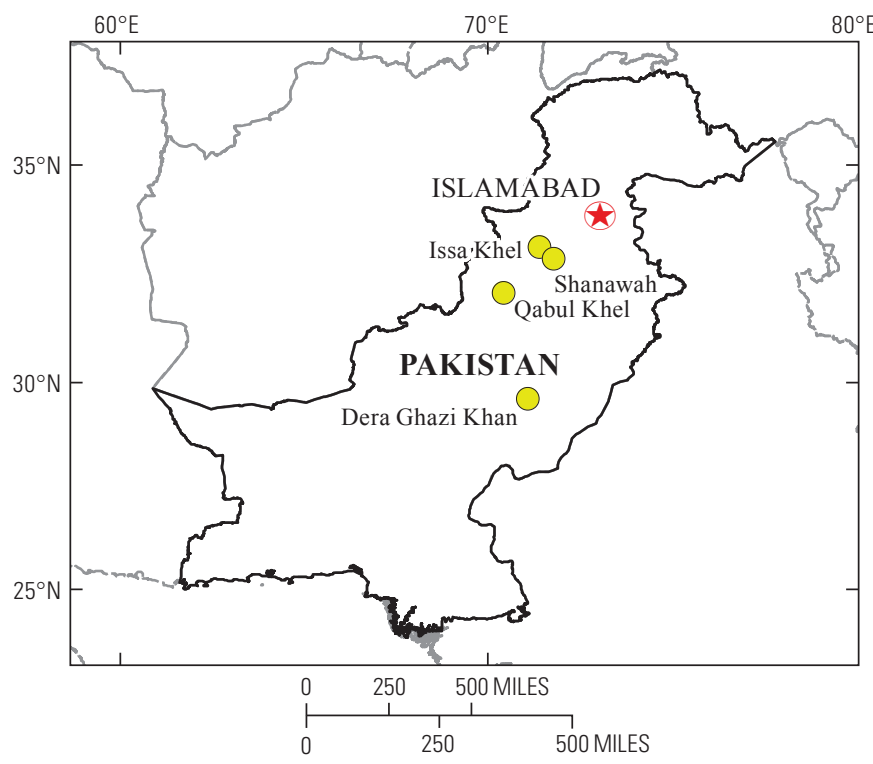

Figure 1-17. Location of uranium mines, production centers and advanced properties in Pakistan. From Dahlkamp (2010).

decreased significantly during the past decade, due to depleted resources and closing of unprofitable production facilities. The "Energy Strategy of Romania," a report on domestic reserves spanning the years 2007-2020, states that RAR are sufficient to supply domestic nuclear energy requirements for the 10 years through 2020 (Ux Consulting Company LLC, 2010). In 2010, the Romanian government provided UNC with subsidies for production of $45 \mathrm{tU}$ (Ux Consulting Company LLC, 2010).

Romania's last submission to the NEA "Red Book" was in 2002. In 2009, the IAEA Secretariat estimated Romania's reasonably assured resources (RAR) at 3,100 tU, and its inferred resources at 3,600 tU (NEA-IAEA, 2010). Other 
estimates report a total reserve of 8,769 for mines in the Banat Region, Bihor (Apuseni Mountains), and Crucea (Eastern Carpathians) regions (fig. 1-18) (Ux Consulting Company LLC, 2010). Past and present production of $38 \mathrm{tU} / \mathrm{yr}$ is expected to continue through 2019 (Ux Consulting Company LLC, 2010). Reports in 2009 indicate that production is coming from the Crucea Mine in the Eastern Carpathians (NEA-IAEA, 2000).

\section{Russia}

The Russian Federation is among the top five nations producing uranium, with a total cumulative production of $139,735 \mathrm{tU}$ as of 2008. Russia reported RAR of over $181,000 \mathrm{tU}$, a total that could potentially double after feasibility studies are completed for inferred resources that exceed 300,000 tU (NEA-IAEA, 2010). Most of Russia's uranium is produced from the Priargunsky mining complex, the world's largest uranium-producing center, which has produced a total of $130,000 \mathrm{tU}$ as of 2008 (fig. 1-19) (NEA-IAEA, 2010).

Six Russian uranium deposits are significant. (1) The Streltsovsk district Mining and Chemical Works (PCMCW), (also referred to as "the Priargunsky works") has volcanic caldera deposits where mining is ongoing and for which NEA reports RAR of 102,600 tU, and IR of 26,930 tU, and for which Ux Consulting Company LLC (UXC) reports 118,341 tU. (2) The Dalur production center (Dolmatovskoye ISL mine) is producing uranium; the 2009 "Red Book" reports RAR of 10,970 tU. (3) The Khiagda deposit, which is amenable to ISL mining, has RAR reported as $26,805 \mathrm{tU}$ and has not yet been mined. (4) Vein deposits of the Gornoe deposit have RAR reported as 7,918 tU, and with production anticipated by 2014. (5) Vein deposits of the Olovskaya deposit are reported as $12,200 \mathrm{tU}$, with production anticipated by 2014. (6) The metasomatic Elkon district contains large inferred resources (319,00 tU), with RAR reported as 71,300 tU, with production anticipated by 2015. (NEA-IAEA, 2010; Ux Consulting Company LLC, 2010). Both the Streltsovsk (PCMCW) and Dalur mines are producing uranium, with production anticipated from Olovskaya and Gornoe by 2014, and from Elkon by 2015 (NEA-IAEA, 2010).

The Russian government plans to continue to expand uranium resources, production, and all other steps in the fuel fabrication process to meet the growing needs not only of the Russian nuclear industry but of the global fuel market. In primary supply, their goal is to increase uranium production capacity from 3,521 tU in 2008 (NEA-IAEA, 2010) to 12,000 tU by 2026 (Ux Consulting Company LLC, 2010).

\section{South Africa}

The South African government plans to increase domestic nuclear power generation and to become self-sufficient in all steps of the nuclear fuel cycle (NECSA, 2010). The

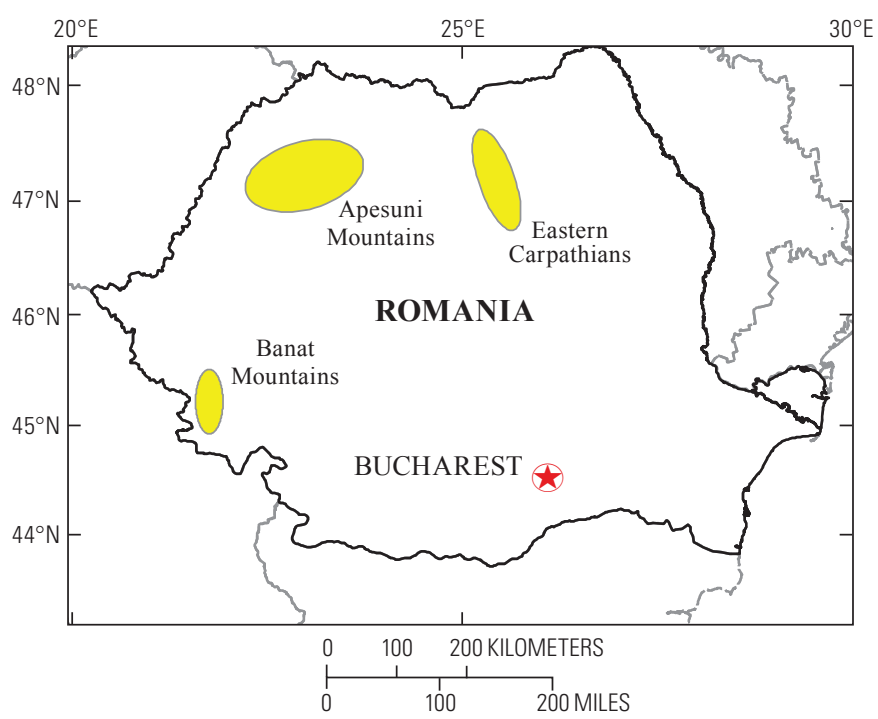

Figure 1-18. Major uranium mining regions of Romania.

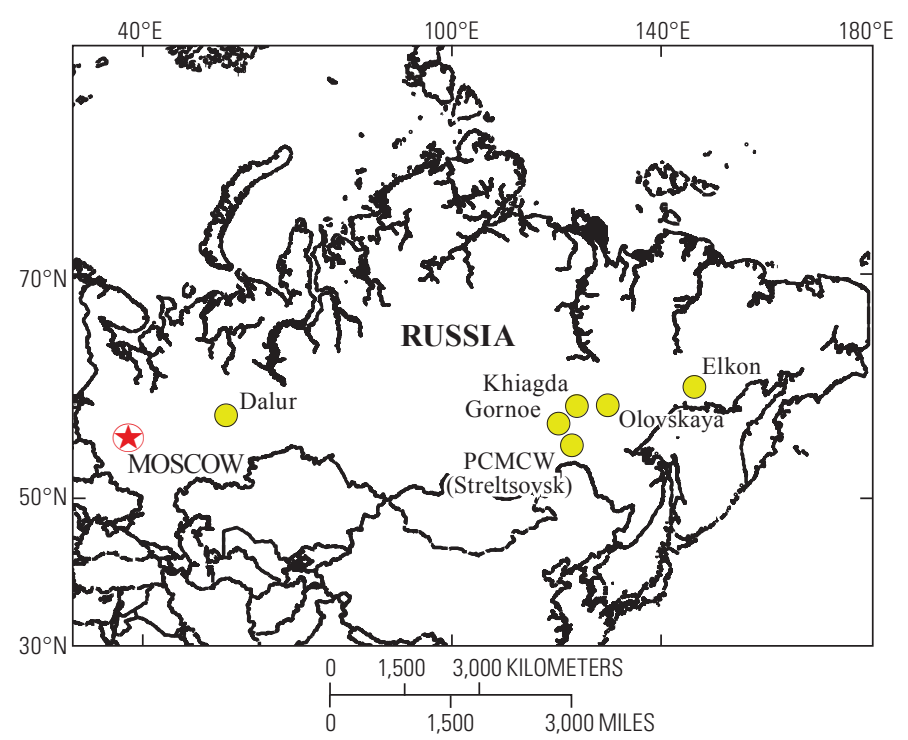

Figure 1-19. Location of major Russian uranium mining and processing districts. From OECD/NEA-IAEA (2010).

government reports an increase in the uranium resource base through renewed brownfield exploration efforts during the five years 2006-2011, and production capacity is expected to double by 2013 (NECSA, 2010).

In South Africa, uranium has been primarily a byproduct of gold mining. Since production began in 1951, most uranium was from underground mines within quartz-pebble conglomerates in the Archean Witwatersrand Basin in the northwest region of the country. Potential for uranium producers expanded quickly in 2007, when brownfield exploration, stimulated by the "uranium beneficiation" program of the South African Government, increased the number of operating and planned uranium-producing mines. 
The two main producers of uranium, the Vaal River and Ezulwini mines, are located within the Witwatersrand Basin, and their combined RAR are reported to contain 17,076 tU (fig. 1-20) (Ux Consulting Company LLC, 2010). The Ezulwini underground mine, about $40 \mathrm{~km}$ southwest of Johannesburg, is owned and operated by the First Uranium Corporation, which estimates more than 4,600 tU in proven and probable reserves, and in measured and indicated resources from underground deposits and from mine-waste tailings (NEA-IAEA, 2010). This report uses a more conservative estimate of measured and indicated resources for Ezulwini: 2,730 tU (Ux Consulting Company LLC, 2010). Production is anticipated to be $500 \mathrm{tU} / \mathrm{yr}$ by 2012 (NECSA, 2010), the increase in production being attributed to expanding underground development at the Ezulwini mine and also to expanding plant capacity of the Mine Waste Solutions (MWS ) tailings recovery facility. The Ezulwini mine is expected to produce through 2030, and the MWS operation is expected to begin producing in 2012, continuing through 2026 (Ux Consulting Company LLC, 2010).

The second main producing mine, the Vaal River mine complex near Klerksdorp, is owned by AngloGold Ashanti Ltd. (fig. 1-20). At Vaal River, three mines are producing uranium as a byproduct to gold production: the Great Noligwa, the Kopanang, and the Moab Khotsong mines. They report RAR of 14,346 tU (NECSA, 2010; Ux Consulting Company LLC, 2010). Anglogold Ashanti Ltd. is the largest producer

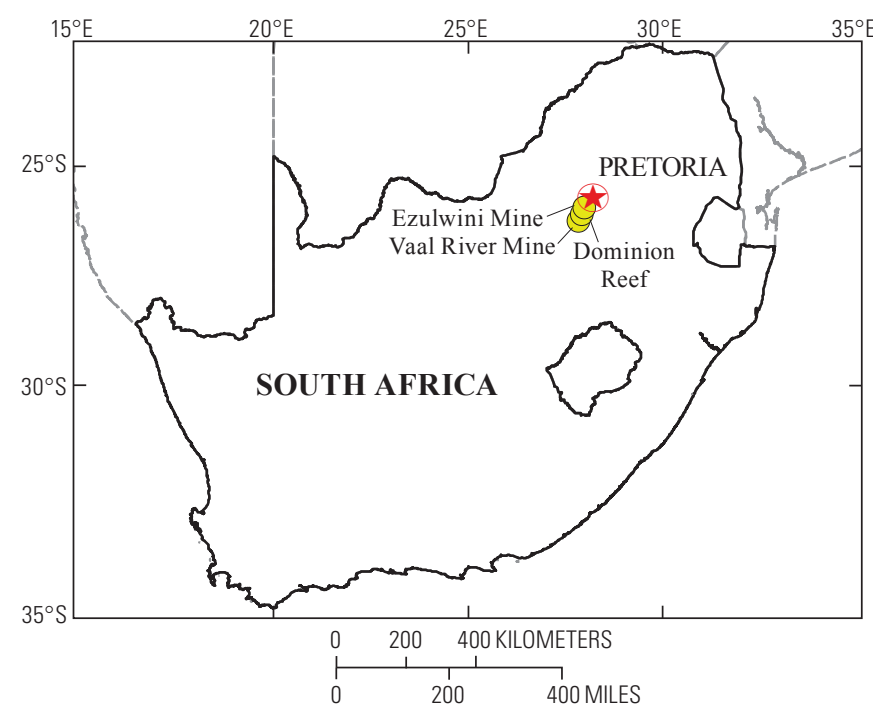

Figure 1-20. Locations of the two operating mines (Ezulwini and Vaal River) and of one mine on standby (Dominion) in South Africa. From OECD/NEA-IAEA (2010). of both gold and uranium-byproduct in the country, reporting RAR of 70,500 tU (IAEA, 2010). The company is expanding the reserve base through exploring extensions of known ore bodies, and it is doubling capacity of its uranium plant by refurbishing and rehabilitating existing facilities. Production exceeded $600 \mathrm{tU}$ in 2009 and is expected to reach more than $1,200 \mathrm{tU}$ by 2012 , leveling out at $1,100 \mathrm{tU}$ in 2014 , and maintaining this level through 2025.

The Dominion Reef deposit is currently on standby. This property was acquired by Shiva Uranium Pty. LLC in 2010 , with plans to rehabilitate the production plant and to resume mining in 2012. Reserve estimates total 55,753 tU, at an average grade of 0.062 percent, with expected production of $425 \mathrm{tU} / \mathrm{yr}$ for 2012. Plans are to increase production to between 850 and $1,460 \mathrm{tU}$ a year by 2013 , and to maintain this level through 2025 (NECSA, 2010). After Shiva's purchase of Dominion, however, significant progress toward production has not been reported for this mine.

Two mines will potentially come online in 2012 and 2017: the Cooke and the Ryst Kuil deposits. Using conventional underground mining methods and processing of tailings, the Rand Uranium Company is developing the Cooke property, which is outside Johannesburg in the Randfontein region within the Elsburg and VCR Reef deposits. The company was formed in 2008 to expand historic gold-producing mines into large-scale uranium and gold operations, capitalizing on surface resources contained within the Cook Tailings Dam. During the three years 2012-2015, the company is focusing on developing a uranium processing plant, expanding underground mining, and recovering uranium from tailings. Production of this Cooke resource of 9,464 tU is scheduled to commence in 2012 at a rate of $425 \mathrm{tU} / \mathrm{yr}$. Underground mine life is expected to last at least 10 years through 2022, and the tailings feed to last for 17 years, to 2030 .

The Ryst Kuil sandstone deposit (Areva joint venture with AngloGold Ashanti Ltd.) in the Karoo region has historic RAR of 7,731 tU (Ux Consulting Company LLC, 2010). Current exploration is underway, with the goals of updating estimates of reserves and of resources, starting commercial production in 2017-2018 at a rate of 1,136 tU/yr, and producing molybdenum as a significant byproduct (NEA-IAEA, 2010; Ux Consulting Company LLC, 2010).

Other less certain plans for developing South African uranium resource prospects involve properties owned by Mintails Ltd., Witwatersrand Consolidated Gold Resources Ltd., Niger Uranium SA, and Harmony Gold Mining Company Ltd., with reported measured and indicated resources totaling 35,196 tU (table 3). 


\section{Spain}

Spain reports 2,500 tU in the cost category of $<\mathrm{USD} 80 \mathrm{~kg} / \mathrm{U}$, and it reports $2,400 \mathrm{tU}$ in the cost category of $<$ USD 130/kgU (NEA-IAEA, 2010). A past producer, there is currently no uranium production from Spain. Berkeley Resources Ltd. (Berkeley) is actively exploring in the country in the Salamanca and Caceres areas (fig. 1-21). Berkeley also holds mineral tenements in the Calaf region where uranium is found in lignite seams. In 2009 Berkeley reached a collaborative agreement, along with ENUSA Industrias Avanzadas SA with Spain's Council of Ministers to complete a feasibility study at the Salamanca I deposit (NEA-IAEA, 2010) Salamanca I is anticipated to produce $769 \mathrm{tU} / \mathrm{yr}$ from a 30,926-tU deposit, beginning in 2014 (Ux Consulting Company LLC, 2010).

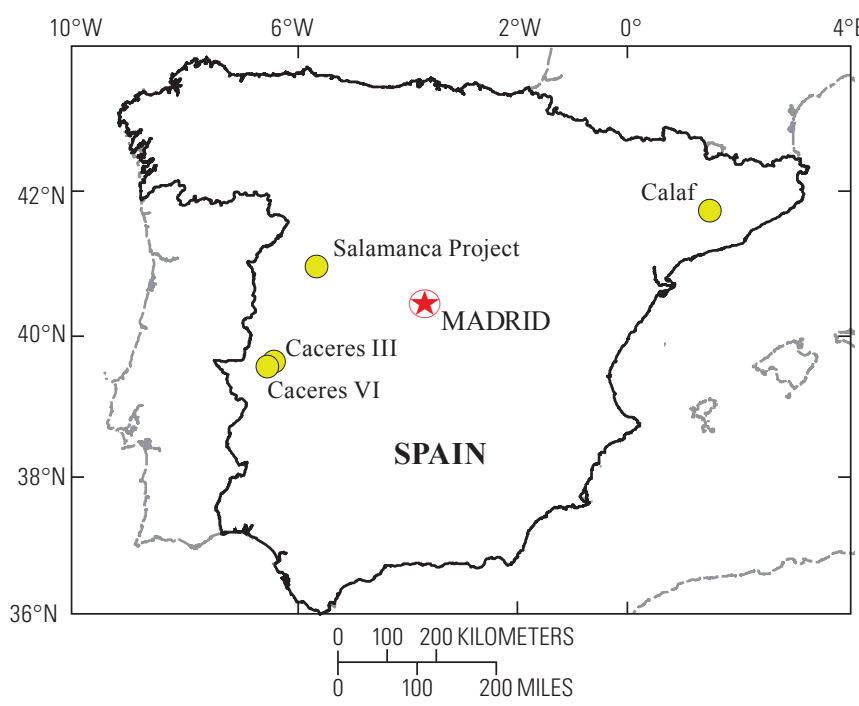

Figure 1-21. Location of active uranium exploration projects in Spain. From Berkeley Resources Ltd. (2011).

\section{Ukraine}

The Ukraine government is in the process of increasing domestic nuclear capacity and uranium production, with plans for doubling 2010 domestic production by 2013 . Although domestic uranium production supplied 30 percent of Ukraine's nuclear energy requirements in 2008, increased domestic uranium production is expected to supply 100 percent of the country's nuclear energy requirements by 2012 (NEA-IAEA, 2010). All aspects of the uranium and nuclear industry are state-owned and controlled, operating under the Vostochny Integrated Mining and Concentrating Plant (VostGOK).

In 2008, Ukraine reported $161,601 \mathrm{tU}$ in the RAR category. To date (2011), most of Ukraine's uranium $(>100,000 \mathrm{tU})$ has been extracted from metasomatite deposits within the Kirovograd block of the Ukrainian Shield, using conventional underground mining methods and underground block leaching techniques. Remaining RAR deposits are estimated at about $142,000 \mathrm{tU}$, at grades of $0.1-0.2$ percent U (NEA-IAEA, 2010; Ux Consulting Company LLC, 2010). The remaining RAR $-6,900 \mathrm{tU}$ in sandstone deposits within the sedimentary cover of the Ukrainian Shield, at grades of 0.01-0.06 percent U-are amenable to ISL mining.

Production centers include (1) the Hydrometallurgical Plant (HMP) in Zheltiye Vody plant, which has been operating since 1958 and currently produces $1000 \mathrm{tU} / \mathrm{yr}$ from the Michurinskoye, Central and Vatutinskoye deposits through the processes of acid leach, solvent extraction, and ion exchange (NEA-IAEA, 2010); (2) the new processing facility Novokonstantinovskoye HMP in the Kirovograd District, which is expected to reach a capacity of 2,500 tU year by 2015 (NEA-IAEA, 2010); and (3) the Safonovskoye ISL plant in the Kazanofsky District, with planned production of $150 \mathrm{tU} / \mathrm{yr}$ in 2012 (Ux Consulting Company LLC, 2010) (fig. 1-22).

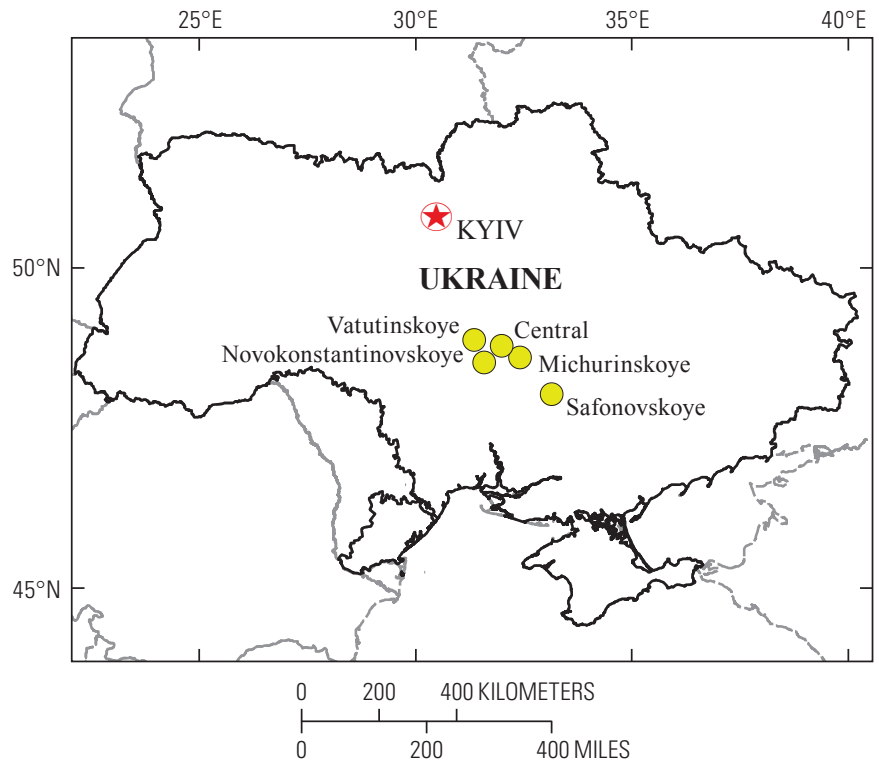

Figure 1-22. Uranium production centers in Ukraine. From Bakarzhiyev, (2011). 


\section{United States}

The following description of U.S. uranium resources includes only the publicly available estimates of resources associated with operating or with developing mines; it does not include United States RAR that are included in other estimates by the EIA uranium reserve, because the EIA considers this information to be proprietary and therefore protected.

Mines in the United States produced 3.7 million pounds. $\mathrm{U}_{3} \mathrm{O}_{8}(1,577 \mathrm{tU})$ in 2009 and 4.2 million pounds $\mathrm{U}_{3} \mathrm{O}_{8}(1,615 \mathrm{tU})$ in 2010 (Energy Information Administration, 2011). During the fourth quarter of 2011, five ISL operations, with a combined reserve of $14,737 \mathrm{tU}$, were in production: the Alta Mesa and the La Palangana mines in Texas, the Crow Butte operation in Nebraska, and the Smith Ranch-Highland mine, and the Willow Creek mine in Wyoming. Several small conventional mines on the Colorado Plateau operated intermittently during this time, with all ore processed at the Denison Mines Corp. (Denison) White Mesa Mill in Blanding, Utah (purchased by Energy Fuels Inc. in 2012).

In-situ leaching operations produce most of the uranium concentrate in the United States, and most developing mines in the country use this process. Currently operating
ISL plants report more than 7,000 tU of demonstrated economic resources, and more than $61,000 \mathrm{tU}$ are associated with developing ISL operations. Uranium-bearing sedimentary deposits amenable to ISL are in abundance in the Gulf Coast Province in Texas, in Wyoming basins, in the Crawford Basin of Nebraska (Black Hills-Northern Great Plains Province), and in the Grants district of New Mexico (fig. 1-23).

The United States has significant uranium deposits in areas where geologic factors require mining of uranium ore by conventional underground or openpit mining techniques, such as the high-grade breccia pipes of the Arizona Strip and the uranium-bearing sandstones of the Uravan Mineral Belt. Development of underground and openpit uranium mining is limited by higher costs for extraction, transportation costs, and limited milling capacity. In December 2010, operating underground mines within the Colorado Plateau, the Arizona Strip, and the Uravan Mineral Belt contained more than 3,000 tU in economic resources. Developing underground and openpit mines report more than $12,000 \mathrm{tU}$ in demonstrated economic resources. Ore from these mines is currently processed at the White Mesa Mill, which has an operating capacity of 2,000 tU/yr. In 2011, the White Mesa Mill was supplied with ore mined from underground mines from the Arizona Strip

\section{United States Uranium Provinces, Districts, and Important Deposits}

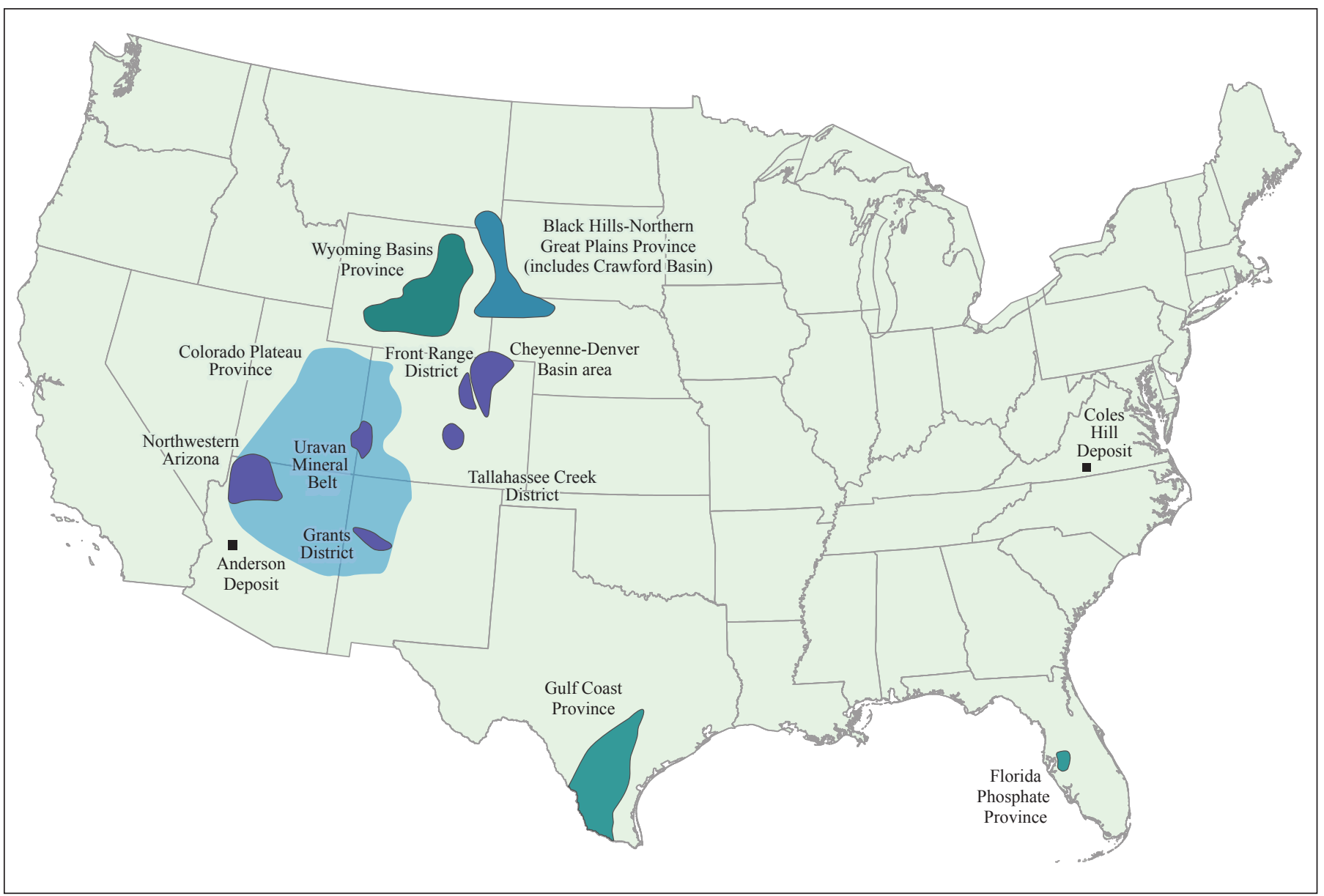

Figure 1-23. Uranium province map of the United States. 
(Arizona One mine) and from the Colorado Plateau District (Pandora and Daneros mines). Three other existing mills with a total capacity of 4,150 short tons of ore per day were on standby: the Canon City Mill in Colorado, the Sweetwater Uranium Project Mill in Wyoming, and the Shootaring Canyon Uranium Mill in Utah. One planned mill in western Colorado, Energy Fuel's Piñon Ridge, is almost fully permitted (Energy Fuels Inc., 2012).

The development timeline for mines in the United States is long, and the major hurdle to production continues to be regulatory uncertainty. The Coles Hill deposit in Virginia (Virginia Uranium Inc.; 27,656 tU) cannot currently be developed due to the State's moratorium on uranium mining and is therefore not included in this review of world supply. Development is proceeding at a much more rapid pace in States considered friendly to mining, such as Wyoming, whereas development is at a virtual standstill in States with active groups opposed to uranium mining, such as New Mexico.

\section{Uzbekistan}

Uzbekistan is one of the world's top 10 uranium producers. The country has no national uranium requirements and exports all the uranium it produces. The Navoi Mining and Metallurgical Complex (Navoi MMC), owned by the Uzbekistan government, controls all aspects of uranium resource exploration and production.

Uzbekistan's uranium resources are in sandstone and black shale deposits, with production only coming from the sandstone deposits. Cenozoic and Mesozoic sedimentary basins host the uranium-bearing sandstones in a $125-\mathrm{km}$-wide belt that extends more than $400 \mathrm{~km}$ from Uchkuduk in the northwest to Nurabad in the southeast. All current and planned production is by in-situ leaching from sandstone deposits. The black shale deposits are breccia complexes hosted by deformed Precambrian-Paleozoic carbonaceous and siliceous schists. Mineralization within the black shales includes uranium-vanadium-phosphate ores and could be mined by openpit and by heap-leaching, but there are no immediate plans (as of 2005) to mine these deposits (NEA-IAEA, 2006).

Uranium is produced by Navoi MMC from three production centers that have all been operating since 1960s: (1) the Northern Mining Division (Uchkuduk District), (2) the Southern Mining Division (Zafarabad District), and (3) Mining Division \#5 (Nurabad District) (Dahlkamp, 2010) . Annual production all from ISL mines and was 2,300 tU in 2005, with plans to increase to 3,000 tU/yr through 2040 (fig. 1-24).

Uzbekistan has not reported uranium resource information to the NEA since 2005. The 2009 "Red Book" reports resource estimates based on the IAEA Secretariat's adjustments of the 2005 data reduced by past production. For 2010 NEA estimates RAR of 76,000 tU and IR of 38,600 tU (NEA-IAEA, 2010). The Ux Consulting Company LLC reports RAR of 108,441 tU, which is fairly consistent with NEA's reporting (Ux Consulting Company LLC, 2010).

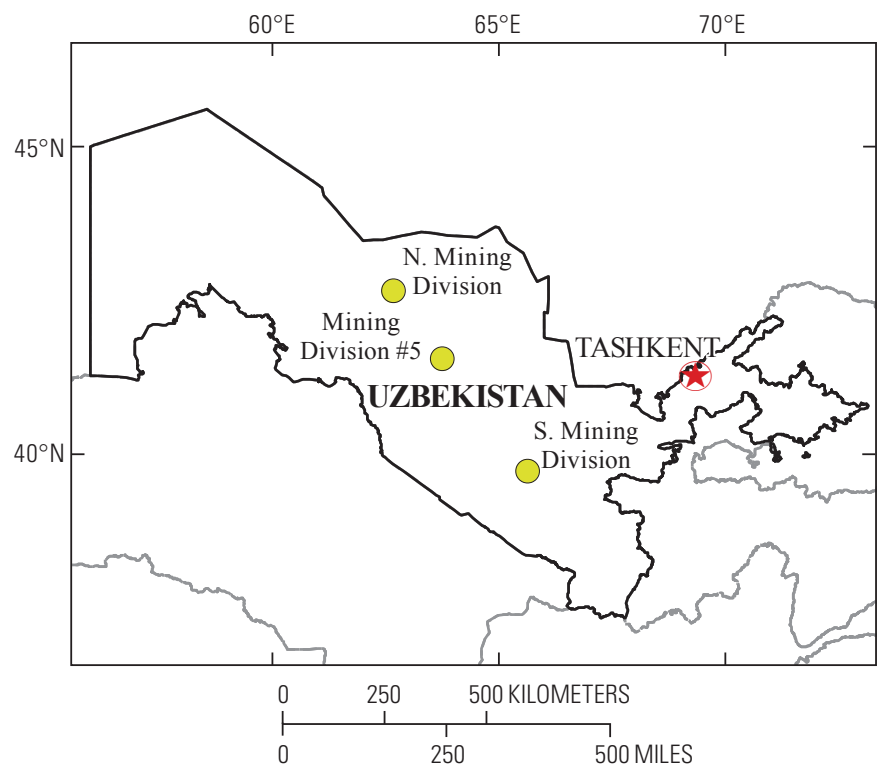

Figure 1-24. Active uranium mining districts in Uzbekistan. From NEA-IAEA (2006).

\section{Other Countries}

Nineteen countries, in addition to these 24 discussed above, are listed in the 2009 "Red Book" as containing RAR but as currently not producing uranium (table 6) (NEA-IAEA, 2010). For example, all the following countries contain resources but the resources are in the highest cost category of USD 260/kgU: France (9,000 tU), Mexico (1,300 tU), Tanzania $(8,900 \mathrm{tU})$, Slovakia $(5,100 \mathrm{tU})$, Somalia $(5,000 \mathrm{tU})$, and Vietnam (1,000 tU). These economic barriers may well account for the lack of production (NEA-IAEA, 2010).

Algeria reports 9,500 $\mathrm{tU}$ in the top two cost categories. Significant exploration has been carried out in this country, but no uranium production is reported (NEA-IAEA, 2008). Chile last reported RAR of 1,034 tU in an undesignated cost category (NEA-IAEA, 2008). These resources are in lowgrade surficial deposits $(\sim 0.02$ percent $U)$, in metasomatic deposits $(0.03-0.20$ percent $U)$, and in one volcanic deposit, El Laco (0.01-0.18 percent U). In 2009, the IAEA Secretariat revised this estimate, adjusted for recovery factors, to $800 \mathrm{tU}$ in the highest cost category (NEA-IAEA, 2010). Although no production has been reported from Chile, an estimated $7,256 \mathrm{tU}$ could be recovered as a byproduct resource in the active Chuquicamata copper deposit and in the Bahia Inglesa and Mejillones phosphate deposits (NEA-IAEA, 2006).

Gabon produced uranium before 2006; the 2009 "Red Book" reports 4,800 tU in the second highest cost category. Areva and Pitchstone Exploration Ltd. have active exploration campaigns in Gabon (NEA-IAEA, 2010; Ux Consulting Company LLC, 2010).

Indonesia has never produced, nor is it currently producing, uranium, but it reports $4,800 \mathrm{tU}$ at $<\mathrm{USD} 130 \mathrm{~kg} / \mathrm{U}$ (NEA-IAEA, 2010). Although uranium deposits in Indonesia are well known, exploration is minimal and development is not likely in the foreseeable future (Dahlkamp, 2010). 
The 2009 "Red Book" credits Italy with 4,800 tU in the $<$ USD $130 \mathrm{~kg} / \mathrm{U}$ cost category (NEA-IAEA, 2010). Italy passed a series of legislative packages during 2008 through 2010 that emphasized the importance of nuclear power. An assessment of prospective ground in the northern Alps near Switzerland was undertaken in an attempt to stimulate foreign investment (Vettraino, 2010). In 2011, following Fukushima, the nuclear policy of Italy was effectively reversed, ceasing investigations at least through 2016 (Vettraino, 2011).

The 2009 "Red Book" reported Japan as having 6,600 tU in the cost category of $<$ USD $130 \mathrm{~kg} / \mathrm{U}$ (NEA-IAEA, 2010). Japan has historically produced minimal uranium. Known resources are attributed to the Tono and the Ningyo-Toge deposits (Dahlkamp, 2010). Pilot-test mining of Ningyo-Toge during 1964-1982 yielded a small amount of uranium (87 tU), and this facility has been dismantled. Underground development of the Tono deposit was initiated, but this deposit is not active. Japan imports all its uranium, and Japanese utilities are involved in exploration and mining ventures worldwide. Japan has been on the forefront of developing technology for extracting uranium from seawater.

Peru reported 1,300 $\mathrm{tU}$ in the cost category of $<$ USD 80/kgU in the 2009 "Red Book". This resource is from the Macusani area, currently being explored by Macusani Yellowcake Inc., Mega Uranium Ltd., South Andes Energy Inc., and Vena Resources Inc. (Vena) (Mega uranium Mining Company, 2011). Vena reports a 7,997 $\mathrm{tU}$ reserve for their deposit in the Macusani area, jointly held with Minergia S.A.C. This resource is still being explored, and has not progressed to the feasibility stage (Ux Consulting Company LLC, 2010). Peru has favorable geologic attributes for uranium mineralization, and exploration groups are active in some districts. The possibility of this country becoming a producer in the near future continues to increase as active exploration proceeds.

Portugal reported 4,500 $\mathrm{tU}$ in the cost category of $<$ USD $80 / \mathrm{kgU}$, and an additional 1,500 tU in the higher cost 2009 "Red Book" category of <USD 130/kgU(NEA-IAEA, 2010) . Portugal has produced uranium, but not since 2001, and nuclear energy is not considered in the current national energy policy. Some private companies have expressed interest in exploring the Nisa uranium property, but none has yet been granted mineral rights (NEA-IAEA, 2010).

The IAEA Secretariat estimated that Slovenia contains $1,700 \mathrm{tU}$ in the 2009 "Red Book"'s cost category of $<$ USD 130/kgU in 2009 (NEA-IAEA, 2010). This resource is attributed to the Zirovski deposit, owned by the Republic of Slovenia, which the government decided to decommission in 1994. Slovenia has not had recent or ongoing exploration or mine development activities, and is unlikely to contribute to the world uranium supply in the near future.

Sweden reported $400 \mathrm{tU}$ in the cost category of $<$ USD 130/kgU in 2009 (NEA-IAEA, 2010). Since 2007, exploration has increased in Sweden, with black shale deposits containing a very large potential resource. The Viken deposit is estimated to contain an indicated resource of 20 million $t U$, and inferred resources of 2.4 billion $\mathrm{tU}$ (Puritch and others, 2010). The metallurgy of this deposit precludes easy recovery, however, and Continental Precious Minerals Inc., the company currently exploring the Viken deposit, is reportedly investigating the use of bioleaching technology to leach uranium from these shales. Mawson Resources Ltd. is exploring three deposits of particular note in northern Sweden: the Hotagen unconformity related deposit $(1,270 \mathrm{tU})$; the Tasjo uranium rare-earth deposit (42,300 $\mathrm{tU})$; and the Dubblon volcanogenic deposit containing 3,366 tU (Mawson Resources Limited, 2008; Ux Consulting Company LLC, 2010). Aura Energy Ltd. is exploring low-grade black shales in its Haggan deposit in central Sweden with a reported resource of 114,642 tU, which the company feels might be profitable if coproducts molybdenum, vanadium, nickel and zinc are mined. Sweden is highly prospective, although the black shale and phosphate deposits will require either improved technology or the production of coproducts, or both, in order to be feasible (Ux Consulting Company LLC, 2010). No deposits are yet at the feasibility stage in Sweden, although the active exploration activities in the country may advance these deposits to feasibility in the near future.

Publishing support provided by:

Denver Publishing Service Center, Denver, Colorado

For more information concerning this publication, contact:

Center Director, USGS Central Energy Resources Science Center

Box 25046, Mail Stop 939

Denver, CO 80225

(303) 236-1647

Or visit the Central Energy Resources Science Center Web site at: http://energy.usgs.gov/

This report is available at: http://pubs.usgs.gov/sir/2012/5239 
